UNIVERSIDADE DE SÃO PAULO

FACULDADE DE FILOSOFIA LETRAS E CIÊNCIAS HUMANAS

DEPARTAMENTO DE HISTÓRIA

PROGRAMA DE PÓS-GRADUAÇÃO EM HISTÓRIA SOCIAL

RENATA CABRAL BERNABÉ

\title{
A construção da missão japonesa no século XVI
}

Versão corrigida

São Paulo 


\title{
RENATA CABRAL BERNABÉ
}

\section{A Construção da Missão Japonesa no Século XVI}

\author{
Dissertação apresentada ao \\ programa de pós-graduação em \\ História Social do departamento de \\ História da Faculdade de Filosofia \\ Letras e Ciência Humanas da \\ Univercidade de São Paulo, para \\ obtenção do título de Mestre em \\ História.
}

Orientação: Prof. Dr. Carlos Alberto Moura Ribeiro Zeron

Versão Corrigida

De acordo:

São Paulo, 2012 
加藤クリスチアノへ 


\section{AGRADECIMENTOS}

Inicio minha sessão de agradecimentos da maneira mais clássica possível: agradecendo meu orientador, Carlos Alberto Moura Ribeiro Zeron. Faço isso por uma escolha pessoal e não por qualquer adesão a determinadas tradições acadêmicas. $O$ estudo da história do Japão, um país tão distante geograficamente, se coloca com certa raridade, ou até mesmo ineditismo, em nosso departamento. $\mathrm{O}$ fato de o professor Zeron ter aceitado orientar minha pesquisa, ainda que a mesma seja inédita em diversos aspectos até mesmo para ele, me possibilitou levar adiante os estudos que desde o início da graduação me interessavam e que eu desejava desenvolver. Por outro lado, sua notável capacidade interpretativa e analítica foi essencial para que minha pesquisa se desenvolvesse de maneira mais rica e crítica.

Junto do meu orientador, gostaria também de explicitar meus eternos agradecimentos ao professor que me auxilia e incentiva nos estudos acerca do Japão desde a graduação e que durante todo meu mestrado atuou de maneira informal como co-orientador da minha pesquisa: o professor do departamento de Letras Orientais da FFLCH-USP, Koichi Mori.

Em seguida agradeço a todos os amigos, colegas e familiares que me auxiliaram de uma forma ou de outra na redação da presente dissertação. Victor Vigneron que incansávelmente leu e releu meus projetos iniciais, Vivian Costa que pacientemente dedicou seu tempo para procurar documentos para mim nas bibliotecas de Lisboa, Danilo Nakamura, Fernando Monteiro, Tania Mendonça, Juliana Mantovani, que me incentivaram desde a graduação a prosseguir nos estudos acerca do Japão, a minha família e a Cristiano Kato que pacientemente aguentaram todos os momentos de estresse e nervosismo que se acumularam nos períodos imediatamente anteriores aos diversos prazos que tive que cumprir como mestranda, além de estarem ao meu lado nesse longo caminho que escolhi trilhar ao estudar o Japão e aos bibliotecários tanto das bibliotecas que pesquisei no Brasil quanto as do Japão em Tóquio (Universidade de Sophia) e Osaca (Kansai Language Instituite) que me auxiliaram imensamente na pesquisa bibliográfica e documental. Também agradeço aos meus professores de japonês, particularmente Yasuji Baba, que tanto me ajudou nas diversas traduções, e meus professores da graduação e pós-graduação, em especial Adone Agnolin, membro da banca de qualificação, que me ajudou ativamente no presente trabalho. 
Por fim, no nível institucional, agradeço à Fundação de Amparo à Pesquisa de São Paulo (FAPESP) pelo apoio financeiro e reconhecimento institucional dado à minha pesquisa e à Fundação Japão pela bolsa concedida através do programa de treinamento de japonês para especialistas. 


\section{RESUMO}

Em 1549, os primeiros missionários cristãos chegaram ao arquipélago japonês a fim de evangelizar a população nativa. Chegaram poucos anos após os comerciantes portugueses, mas não ficaram sob sua proteção. Ao contrário destes, não ficaram apenas nas cidades portuárias, mas adentraram-se no território japonês que passava por um século de sangrentas guerras, num longo processo de unificação do território por um poder central, que só terminaria no século seguinte. Os jesuítas, ordem que manteve o monopólio da evangelização do Japão até o ano de 1593, acabaram por se envolver no complexo jogo político de então, à procura de patronos e proteção para que pudessem espalhar o Evangelho dentre a população nativa. Sem qualquer proteção garantida a maneira que encontraram para cristianizar os japoneses foi implicarem-se na política local tentando convencê-los de que o cristianismo era a verdadeira religião. A forma como se deveria dar esse processo de convencimento não foi, contudo, consenso entre os jesuítas, que acabaram se dividindo acerca do melhor método. Se de um lado o Visitador Geral das Índias Orientais, Alexandre Valignano, formulou um método inovador, denominado pelo próprio como acomodação (ou accomodattio em italiano), uma outra parcela da ordem, encabeçada pelo segundo superior da missão japonesa, Francisco Cabral, discordava, afirmando que o processo de evangelização deveria sempre priorizar os regramentos da Ordem para não correr o perigo de extraviar a mensagem. O objetivo da presente dissertação é, portanto, mapear e compreender essas duas diferentes estratégias de evangelização, tanto para a missão para a qual foi criada, no Japão, quanto para os seus agentes, os jesuítas.

Palavras-chave:

Missão, Jesuítas, Evangelização, Acomodação, História do Japão. 


\begin{abstract}
:
In 1549, the first Christian missionaries arrived in Japan to evangelize the natives. They arrived some yearsafter the Portuguese traders, but did not stay under their protection. On the contrary, the missionaries entered the Japanese territory by their selves, while the traders stayed only in the port cities. At that time Japan was emerged in many civil wars in a period called Sengoku Jidai (the country at war). The Jesuits - the denomination that hold the monopoly of the Japanese mission until 1593 - saw their selves involved in a complicated political plot. As they could not count on any secular protection, they chose to look for the warlords (daimyō) protection to accomplish the evangelization of the Japanese people. The only way for that was the convincement of the people that Christianity was the true religion. Nevertheless, even among the Jesuits that went to the Japanese mission, there was not a consensus about the best way to convince the Japanese to become Christians. The Visitor of the Jesuit's missions in Asia, Alexandre Valignano, designed a new method called accomodatio, but some Jesuits were against it. Led by the second Superior of the Japanese mission, Francisco Cabral, they claimed that accomodatio was not the best way once it could mislead the neophytes. What they should do, in Cabral's point of view, was to follow strictly the rules of the Society of Jesus. The aim of this essay is to understand these two methods of evangelization and their meaning for both the Jesuits and the Japanese.
\end{abstract}

Key words:

Mission, Jesuits, Evangelization, Accomodatio, Japan's History. 
まとめ :

1549 年、最初のキリシタン宣教師が来日しました。その数年前にポルトガルの 商人が来日しましたが宣教師たちには商人としての保護はなっかたため、港町 にだけは行きませんでした。彼らは日本の領土に入りましたが、このとき日本 は戦国時代で、17 世紀までの全国統一の過程を歩んでいました。イエズス会は、 1593 年までの日本への布教団のうちキリシタン宗派の任務を行っていました。 大名による保護を模索するうちに、イエズス会の宣教師たちは複雑な政治状況 に巻き込まれました。イエズス会の宣教師の間で一番よい布教方法には総意が ありませんでした。Alexandre Valignanoは「イエズス会のアジアの訪問者」に おいてで新しい布教方法を策定しました。Accomodatio という方法でした。反 面、Francisco Cabral は「日本の布教団のリーダ」で反論しました。イエズス 会の規律だけを守れば良いと考えました。この論文の目的は、その二つの方法 を理解するである。

キーワード :

布教団、イエズス会、布教、Accomodatio、日本史。 


\section{Sumário}

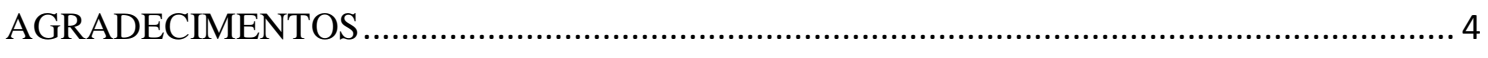

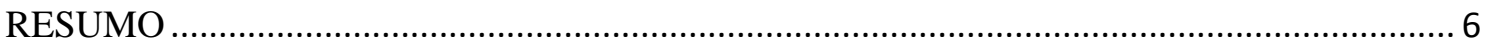

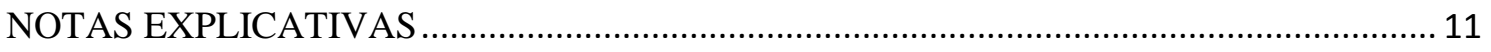

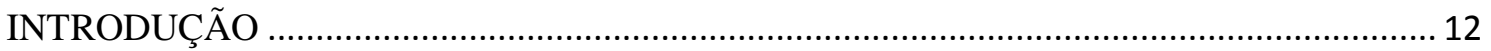

Cap. 1 - O Período Sengoku e o Século Cristão Japonês ........................................................... 18

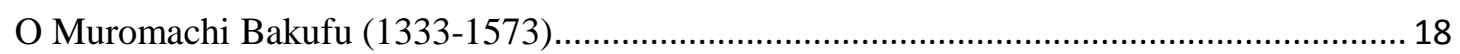

A guerra civil de Onin e o período Sengoku - a Era das Províncias em Guerra...................... 19

Fim do Muromachi e Período Azuchi Momoyama ................................................................ 23

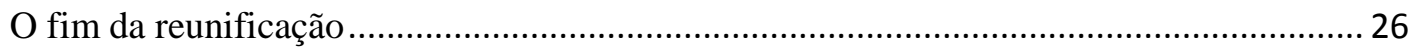

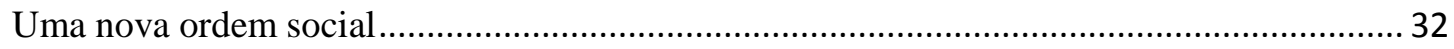

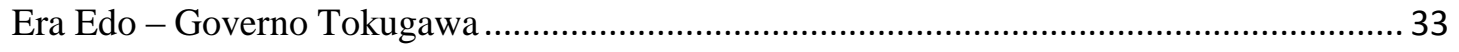

A importância do comércio nas relações entre o Japão e o Ocidente ……………………….... 34

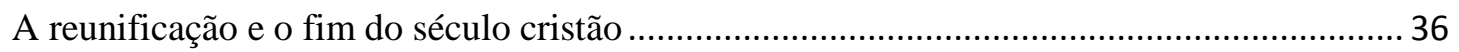

Cap. 2. A missão cristã durante o superiorato de Cosme de Torres (1551-1570) ........................ 47

OS PORTUGUESES NA ÁSIA E A CHEGADA DOS JESUÍTAS NO JAPÃO.................... 47

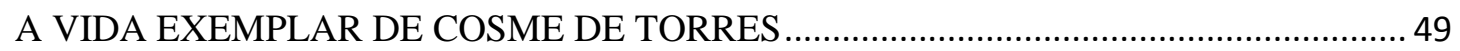

OS JAPONESES E A NOVA APOSTA DA COMPANHIA …............................................. 51

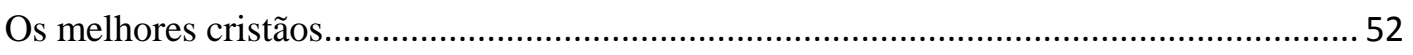

A RELAÇÃO COM AS CRENÇAS LOCAIS ..................................................................... 55

A EVOLUÇÃO DA MISSÃO E O PAPEL DO SUPERIOR UNIVERSAL DO JAPÃO ......60

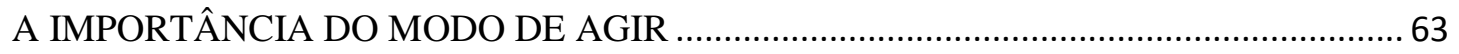

A IMPORTÂNCIA DAS MISSIVAS DENTRO DA COMPANHIA DE JESUS ...................67

Cap. 3. A missão cristã durante o superiorato de Francisco Cabral (1570-1581) ......................... 70

COSME DE TORRES E A ESCOLHA DE FRANCISCO CABRAL …................................. 70

O PROGRESSO DA MISSÃO - A CRISTIANIZAÇÃO DA ELITE ....................................... 71

O PAPEL DAS ELITES JAPONESAS NA MISSÃO ............................................................. 74

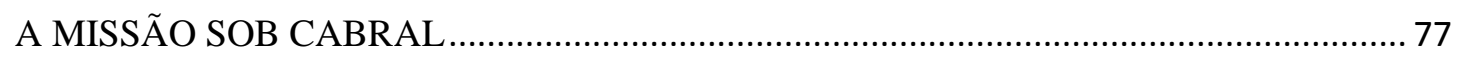

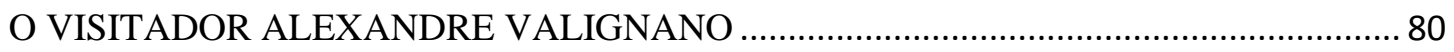

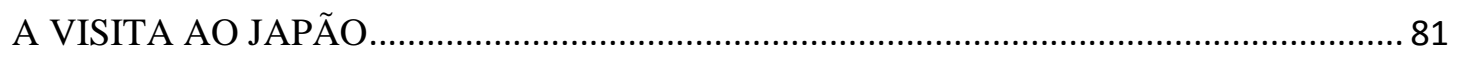

O RESULTADO FINAL DO ANTAGONISMO ENTRE CABRAL E VALIGNANO......... 84

A PROPOSTA DE VALIGNANO PARA O JAPÃO E O SUMÁRIO...................................... 85

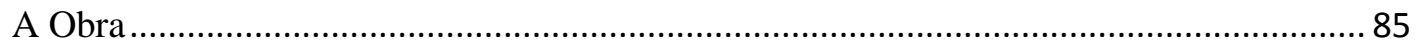

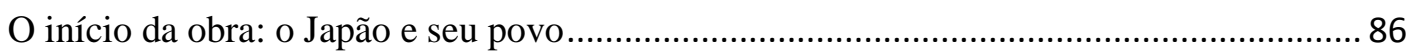


A província do Japão após a visita de Valignano...................................................................... 90

A missão japonesa: a proposta de Valignano ……….............................................................. 92

A CRÍTICA A VALIGNANO - A VISÃO DE CABRAL ..................................................... 99

A evangelização dos japoneses na visão de Cabral.......................................................... 100

A visão do povo japonês - Cabral e Valignano …………………………………........... 102

O PAPEL DA QUERELA NO CONTEXTO DA MISSÃO JAPONESA …………............. 105

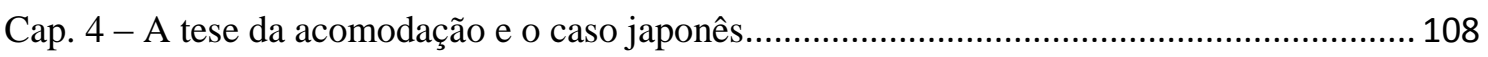

O EXPERIMENTALISMO DA ACOMODAÇÃO - O JAPÃO …........................................ 108

ACOMODAÇÃO - IMPLICAÇÕES E NECESSIDADES …............................................... 110

AS PRÉVIAS E GUIAS DA ACOMODAÇÃO................................................................. 113

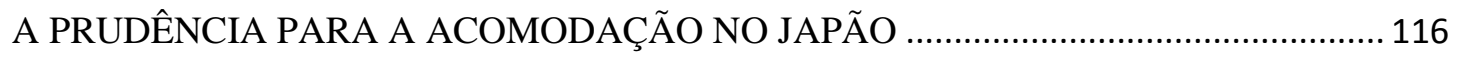

A FALÊNCIA DA ACOMODAÇÃO PARA O JAPÃO ………………............................... 119

ACOMODAÇÃO - UMA NOVA MENTALIDADE .................................................... 124

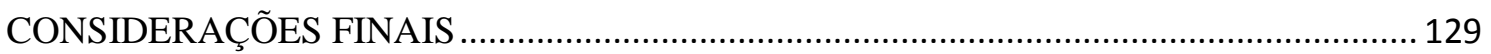

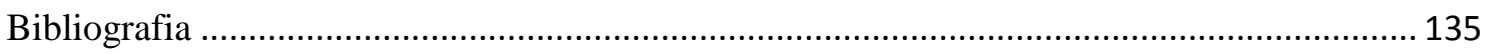

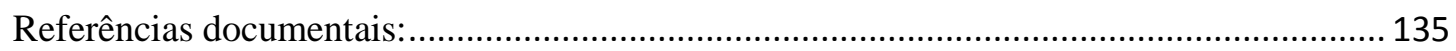

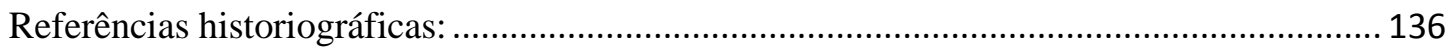




\section{NOTAS EXPLICATIVAS}

Para a transcrição dos vocábulos japoneses seguimos o sistema de transcrição Hepburn, indicando os prolongamentos através do seguinte símbolo: $\bar{o}$ ou $\bar{u}$. No tocante aos nomes próprios de personalidades japonesas do período retratado seguimos a forma japonesa, ou seja, o sobrenome anteposto ao nome. Para os nomes dos europeus, assim como dos autores japoneses contemporâneos, manteve-se a forma ocidental de nome e sobrenome.

No tocante à documentação dos jesuítas não tivemos acesso a nenhum manuscrito, mas somente a coletâneas editadas e impressas. Todas estão devidamente citadas. Estas, por sua vez, com exceção da obra editada por Jorge Álvarez-Taladriz, transcreveram os documentos segundo a ortografia da época e de seus autores. Para o caso dos documentos editados por Taladriz na Monumenta Nipponica Monographs houve a transcrição para o espanhol moderno, assim como a utilização do sistema Hepburn para os vocábulos japoneses, daí a diferença para a ortografia utilizada pelos missionários da época. 


\section{INTRODUÇÃO}

Data do ano de 1542 o primeiro relato de um europeu que tenha pisado em solo japonês. Foram três portugueses que comercializavam no oriente asiático e tiveram sua embarcação levada acidentalmente por um tufão à ilha japonesa de Tanegashima. Segundo seus relatos, os nativos os receberam bem e os ajudaram a retornar a salvo para o continente. Três anos depois, o reino de Portugal iniciou um lucrativo comércio com o Japão. Contudo, esses portugueses encontraram naquele populoso arquipélago um país mergulhado em guerras civis e prolongadas. O poder central, embora existisse virtualmente, não conseguia impor-se na maior parte do território.

Os comerciantes europeus que para lá foram neste período - inicialmente apenas portugueses; posteriormente holandeses, espanhóis e ingleses - não se preocuparam muito em adentrar o país e relatar a situação política de então. Aportavam seus navios nos portos mais ao sul do Japão e ali faziam seu comércio. Contudo, junto deles vieram os missionários cristãos (apenas jesuítas, de 1549 a 1592, e franciscanos, dominicanos e agostinianos, a partir de então). Estes, por sua vez, não ficaram apenas nas cidades costeiras e portuárias, como os comerciantes. Adentraram-se no novo território para expandirem o quanto pudessem a evangelização da população nativa. Desta forma, acabaram por se envolver na complicada trama política de então.

Pouco mais de meio século depois do primeiro encontro, o poder central japonês se restabelecera. Os comerciantes e missionários europeus foram, assim, testemunhas do longo e sangrento processo de unificação da nação japonesa nas mãos de mais um governo militar: o da dinastia Tokugawa. Contudo, com o poder unificado, os europeus acabaram banidos de qualquer contato com o Japão. A exceção foram os holandeses, que conseguiram autorização para frequentar então somente o pequeno porto artificial de Deshima, em Nagasaki.

Mais do que qualquer desavença entre as nações europeias e o Japão, tal proibição se ancorou numa política implementada pelos Tokugawa, que conseguiram centralizar o poder de facto como jamais acontecera na história japonesa. O período que antecede à chamada Era Edo (1603-1868) ${ }^{1}$, apesar de ser caracterizado pela enorme instabilidade política e guerras intestinas, é também um momento em que novas instituições que deram base à política Tokugawa se formaram. Coincidentemente ou

\footnotetext{
${ }^{1}$ Período de hegemonia do clã Tokugawa.
} 
não, foi também o período em que se deu o primeiro encontro entre europeus $\mathrm{e}$ japoneses em solo nipônico, assim como o auge da curta missão católica no Japão.

A companhia de Jesus foi a ordem que ficou com o monopólio da evangelização do Japão de 1549 (data da chegada de Francisco Xavier, Cosme de Torres e João Fernandez ao arquipélago) até 1593 (data da chegada do primeiro grupo de franciscanos). Durante esse período, o monopólio foi garantido, inclusive por bula papal, graças aos pedidos insistentes dos missionários que lá trabalhavam. Estes alegavam que era necessário manter uma coerência doutrinal no trabalho de evangelização do Japão e que o povo japonês precisaria ser poupado de qualquer controvérsia interna à religião cristã; caso contrário, não seriam convencidos a largar suas antigas crenças e abraçar o cristianismo. Contudo, a verdade é que mesmo dentre os jesuítas não houve um consenso quanto à melhor forma de evangelizar o povo japonês. Uma vez que os missionários não contavam com a ajuda de qualquer poder coercivo no Japão, o método a ser empregado para convencer a população a cristianizarse era de central importância.

Ao fim do segundo superiorato ${ }^{2}$, as propostas se polarizaram entre duas importantes personagens das missões no Oriente: Francisco Cabral, então Superior do Japão, e Alexandre Valignano, Visitador Geral das Índias Orientais. Enquanto o primeiro procurava valorizar a obediência irrestrita das regras da Ordem, o segundo buscava compreender melhor a sociedade japonesa para tentar se inserir nela da maneira menos traumática possível, uma vez que ele a considerava extremamente refinada.

No presente trabalho buscamos compreender um pouco mais acerca desse encontro, justamente através dessas controvérsias. Ao tentar compreender as duas diferentes propostas de evangelização do povo japonês, assim como o motivo de terem sido geradas, ainda que seus autores sejam membros de uma mesma ordem católica, pudemos entender um pouco melhor o efeito que os encontros promovidos pelas Grandes Navegações do século XVI provocaram na mentalidade europeia. Por outro lado, também pudemos perceber que a Igreja Católica e seus agentes formularam em cada missão diferentes respostas para os problemas gerados por esses novos encontros. O caso do Japão é diferente do caso chinês, indiano ou americano e isso não dependeu

\footnotetext{
${ }^{2} \mathrm{O}$ segundo superiorato (1570-1581) teve Francisco Cabral como superior da missão.
} 
apenas do contexto nativo, mas também da postura dos agentes europeus perante cada povo. Ou, como afirma Nicola Gasbarro:

As missões constroem a primeira globalização social e simbólica da modernidade [...]. Para incluir socialmente e compreender simbolicamente, elas são obrigadas a mudar a sua mensagem e perder alguns dos pressupostos iniciais: o cristianismo dos modernos não é o dos antigos e os missionários são os primeiros protagonistas dessa revolução cultural. $^{3}$

Além disso, ao analisar a história do curto período da história japonesa em que o país esteve aberto à presença e consequente influência europeia, podemos perceber que tal controvérsia se coloca como um importante preâmbulo para uma disputa posterior, mais ampla e acalorada, entre jesuítas e franciscanos acerca da missão japonesa.

Para entender melhor essas propostas e as controvérsias, nos utilizamos das cartas e tratados escritos por alguns dos jesuítas que trabalharam na missão japonesa durante os dois primeiros superioratos da missão jesuíta. Os autores escolhidos para compor o corpus documental da presente dissertação foram: os dois primeiros superiores da missão japonesa, Cosme de Torres (cujo superiorato se estende de 1551 a 1570) e Francisco Cabral (de 1570 a 1581), o Visitador das Índias Orientais da Companhia de Jesus, Alexandre Valignano, e o principal cronista da missão cristã no Japão, Luís Fróis.

Fróis foi o único dentre os autores jesuítas escolhidos para o corpus documental da dissertação que não ocupou cargos de chefia nas missões jesuítas do oriente. Dono de um talento particular para escrever, foi, no entento, autor da maior e mais detalhada obra da época acerca da missão japonesa do século XVI e XVII (História de Japam). Seu dom para a escrita foi cedo reconhecido pelos seus contemporâneos, superiores na Companhia. Em 1579, o Padre J. P. Maffei, ao colher documentos e materiais para a sua "História da Índia Oriental", sugeriu ao P. Geral Mercuriano que Luis Fróis, que vivia no Japão e possuía talento na escrita, compusesse um "comentário" do progresso da fé naquele país. Claudio Acquaviva, sucessor de Mercuriano, acolheu tal ideia e escreveu tal pedido ao Visitador Alexandre Valignano, entre 1582 e 1583. Embora Fróis tenha alegado fortes dores nas mãos e braços, acabou por aceitar o encargo e iniciou a obra

\footnotetext{
${ }^{3}$ GASBARRO, Nicola. Missões: a civilização cristã em ação, in: MONTERO, Paula. Deus na Aldeia: missionários, índios e mediação cultural, São Paulo: Globo, 2006, página 75.
} 
em 1585. Já em dezembro de 1586 tinha a primeira parte concluída. Quando acompanhou Valignano, em 1592, para uma viagem a Macau, a obra estava terminada. O Visitador insistiu para que ele a resumisse, pois a mesma estava extremamente extensa, mas Fróis insistiu para que ela fosse enviada a Roma da maneira que se encontrava. O resultado, contudo, foi que Fróis, já velho e indisposto ${ }^{4}$, não pode fazer uma cópia de sua obra e Valignano, desgostoso com tamanha prolixidade, não a enviou para a Europa, tendo ela ficado em Macau, esquecida em alguma casa da Companhia até o século XVIII, quando foi encontrada pela equipe do padre José Montanha (enviada pela Real Academia de História de Lisboa). ${ }^{5}$

Por fim, para enriquecer um pouco o relato dos primeiros anos da missão, fizemos uso também do tratado do padre moralista Francisco Rodrigues (1515-1573), reitor do colégio de São Paulo, em Goa, intitulada "Resposta que alguns Padres de Japão mandaram perguntar". Nesta obra, Rodrigues, que jamais pisara em território japonês, responde a 47 questões acerca dos métodos a serem empregados na evangelização do povo japonês, enviadas entre 1563 e 1568 pelos missionários que trabalhavam no arquipélago.

Tais documentos nos permitiram redesenhar em parte o período em questão, mas o auxílio de uma bibliografia complementar foi essencial, uma vez que foi feita uma seleção dos documentos, não permitindo assim uma compreensão global do desenvolvimento da missão nesses trinta anos. O texto, contudo, aponta, sempre que necessário, a fonte das informações.

A dissertação se encontra dividida em quatro capítulos. O primeiro capítulo é dedicado ao contexto político japonês desde o início do chamado período Sengoku (meados do século XV) até a expulsão final dos portugueses do Japão pelo poder central e a intensa perseguição aos cristãos remanescentes (meados do século XVII). Tal descrição serve não apenas para melhor contextualizar o ambiente no qual a missão jesuíta se desenvolveu, no século XVI, mas também para melhor embasar a ideia de que o fim do "século cristão" ocorreu como consequência do desenvolvimento político do Japão daquele momento. Sendo assim, os missionários, assim como os reinos cristãos

\footnotetext{
${ }^{4}$ Fróis morreu em 1597, em Nagasaki, após uma doença molesta e prolongada.

5 Todas as informações acerca da História de Japam de Luís Fróis foram retiradas do capítulo introdutório escrito por Josef Wicki na edição que ele mesmo fez da História de Japam. In: FRÓIS, Luis, História de Japam. Volume I. Lisboa: Biblioteca Nacional de Lisboa, 1976 (1597).
} 
europeus, não puderam tomar qualquer providência que fosse capaz de mudar o rumo da situação.

Os dois capítulos seguintes referem-se à construção da missão católica pelos jesuítas durante os trinta primeiros anos da mesma. A referência para tal corte temporal são os dois primeiros superioratos da missão. Os capítulos buscam não apenas descrever o andamento da missão, mas também entender seu desenrolar, tendo sempre como base a compreensão das propostas feitas por esses padres para a evangelização do povo japonês.

Por fim, o último capítulo procura analisar o papel que as querelas acerca do método de evangelização dos japoneses tiveram tanto para a Europa quanto para o Japão. Uma vez que a missão japonesa foi encerrada com a política de fechamento da nação (denominada sakoku, em japonês), a compreensão do que todas essas discussões representaram, tendo em vista um contexto mais amplo, é essencial para entender a validade de tal estudo. 


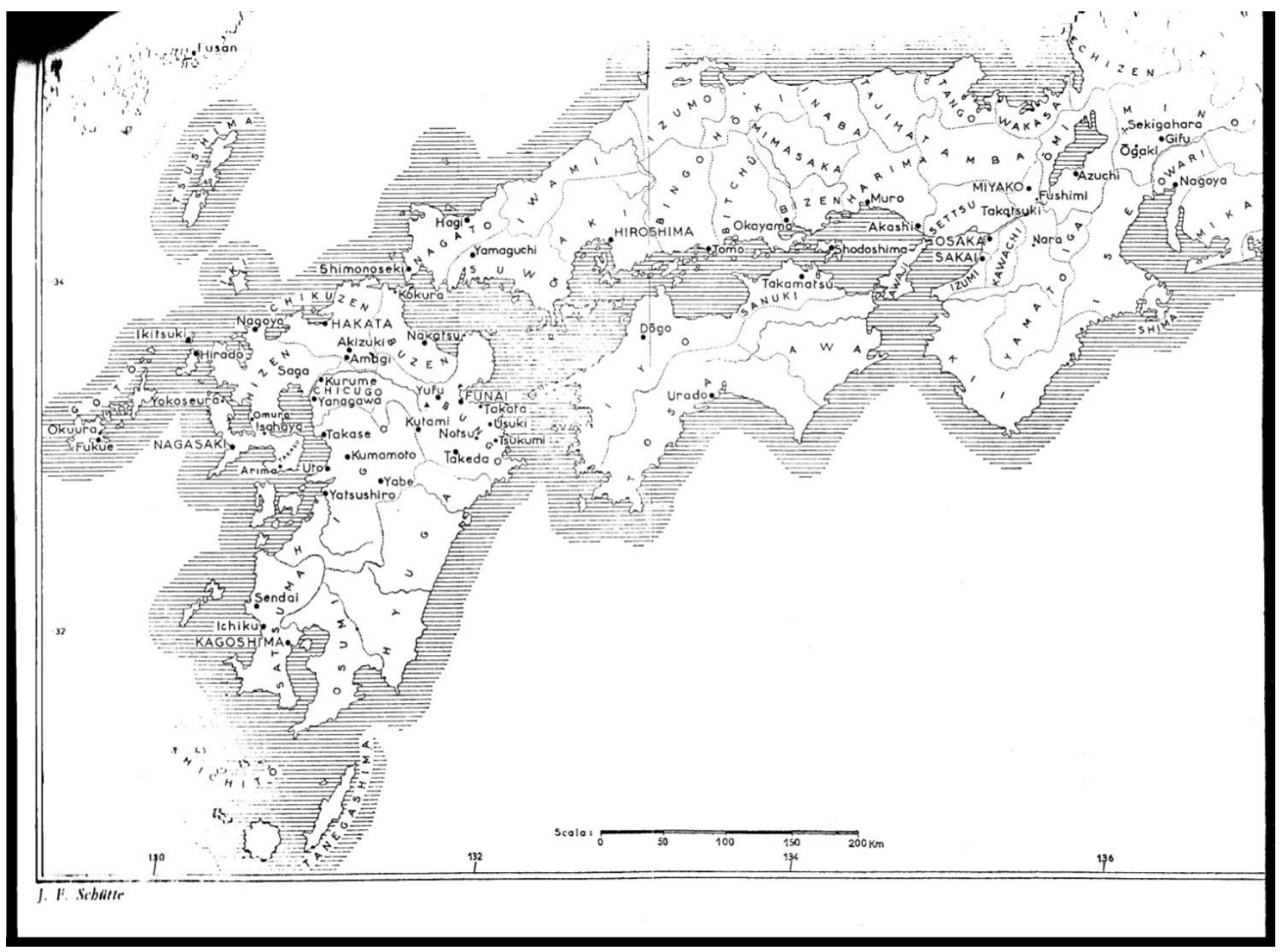

Mapa Japão século XVI. Retirado de: FRÓIS, Luis.História de Japam, volume I, Lisboa: Biblioteca Nacional de Lisboa, 1976 (1592). 


\section{Cap. 1 - O Período Sengoku e o Século Cristão Japonês}

\section{O Muromachi Bakufu (1333-1573)}

$\mathrm{O}$ primeiro encontro entre europeus - sejam mercadores ou religiosos - e japoneses em solo nipônico data de 1542, o que remonta, na periodização clássica da história japonesa, ao período do Muromachi Bakufu ${ }^{6}$. Este foi o segundo dos três governos militares japoneses (Kamakura, Muromachi e Edo) e é caracterizado pela hegemonia do clã Ashikaga. Seu nome provém de um distrito em Quioto onde ficavam a residência e a administração do Ashikaga Bakufu. Na historiografia contemporânea, ele é descrito como um momento de fraqueza política e inquietude social, mas também de esplendor cultural.

Iniciado com a chamada "Restauração Kenmu" (1333-1336), promovida pelo imperador Go-Daigo que, descontente com o governo militar de Kamakura ${ }^{7}$, derrubou o shogunato com a ajuda de importantes aliados da classe militar - tendo sido o mais importante Ashikaga Takauji, aquele que seria posteriormente nomeado como o primeiro xogum $^{8}$ do Muromachi Bakufu. Contudo, Go-Daigo acabou por frustrar seus aliados samurais ao tentar restaurar o poder imperial à custa de uma menor participação da classe militar (buke) na política.

O imperador foi então derrotado por seu antigo aliado, Ashikaga Takauji, que, logo em seguida nomeou seu rival, Komyo, como imperador, o qual, por sua vez, nomeou prontamente Takauji como sei tai shogun?.

O xogunato Ashikaga herdou grande parte da estrutura administrativa do governo anterior de Kamakura, mas diferente deste, o controle sobre os vassalos apontados como shugo (governadores das províncias) foi fraco desde o início. Para o historiador John Whitney Hall:

A dificuldade que os xoguns Ashikaga tiveram em manter o controle sobre regiões mais distantes do país foi uma consequiência da sua falência tanto em desenvolver um aparato

\footnotetext{
${ }^{6} \mathrm{O}$ termo Bakufu refere-se a um governo militar, ou seja, um governo que esteja nas mãos de uma aristocracia militar.

${ }^{7}$ Primeiro governo militar do Japão. Estabelecido por Minamoto no Yoritomo oficialmente no ano de 1192.

${ }^{8}$ Comandante militar do Japão. No presente trabalho utilizarei a grafia aportuguesada do termo e não sua transliteração para o alfabeto romano (shogun).

${ }^{9}$ Grande xogum.
} 
governamental necessário, quanto em adquirir poder suficiente para impor sua hegemonia militar. ${ }^{10}$

Uma das grandes consequências dessa incapacidade do poder central de se impor sobre todo o território nipônico foi a ampliação dos direitos concedidos aos governadores das províncias: os shugo. A falta de finanças que possibilitasse um maior controle dos shugo assim como a crescente preocupação com os kokujin - senhores de terras menores que não possuíam o status de daimyō e, portanto, não estabeleciam relações com o xogum - fez com que o Bakufu concedesse aos shugo maior independência política. Estes passaram, a partir de então, a ser chamados de shugodaimyō.

No entanto, o terceiro xogum Ashikaga, Yoshimitsu (1358-1408), que governou de 1367 a 1395, instituiu a obrigatoriedade dos shugo-daimyō de residirem na capital, Quioto. Seus domínios ficavam, então, confiados aos chamados shugo-dai. Os shugodaimyō, por sua vez, iniciaram o estabelecimento de uma relação - neste momento ainda frágil - com os kokujin locais.

\section{A guerra civil de Onin e o período Sengoku - a Era das Províncias em Guerra}

O Período Sengoku é, na realidade, uma subdivisão do período Muromachi. Seu início data de 1467, ano em que a guerra civil de Onin foi deflagrada, e finaliza em 1568 quando o general que iniciou a reunificação do Japão no século XVI, Oda Nobunaga, entrou na capital Quioto.

A Guerra de Onin e Bummei (mais conhecida apenas como Onin) foi uma longa guerra civil que ocorreu entre os anos 1467 e 1477. Ela envolveu quase todas as casas de shugo-daimyō japonesas e foi bastante destrutiva uma vez que foi lutada nas ruas da capital Quioto.

O motivo inicial dessa guerra foi uma disputa entre as famílias Hosokawa e Yamana pela escolha do herdeiro do xogum Ashikaga Yoshimasa. Este, segundo filho do assassinado Ashikaga Yoshinori, foi nomeado xogum em 1443, quando tinha apenas oito anos de idade. Como ainda era menor, foi colocado sob a guarda do $k a n r e i^{11}$

\footnotetext{
${ }^{10}$ HALL, John Whitney, The Muromachi Bakufu, in: YAMAMURA, Kozo (ed.). Cambridge History of Japan, Volume III, Cambridge University Press, 1990, p. 201/202. (tradução minha)

${ }^{11}$ Cargo criado pelo governo militar anterior (Kamakura), cuja função era dar suporte ao xogum e mediar assuntos com os shugo.
} 
Hosokawa Katsumoto. Yoshimasa acabou sendo declarado maior em 1449, com apenas quatorze anos.

No entanto, o Bakufu, nesse momento, ainda não havia se recuperado da crise causada pelo assassinato do antigo xogum (pai de Yoshimasa) em 1441. Além disso, o país passava por uma crise econômica e o xogum, procurando responder às demandas de samurais e camponeses, baixou um édito de cancelamento de dívidas. Tal medida causou um alvoroço nos mercados e a tentativa de revogar o édito provocou uma série de revoltas e pilhagens. A construção do enorme templo zen-budista Ginkaku-ji (pavilhão de prata) enfraqueceu ainda mais os já debilitados cofres do Bakufu.

A querela acerca da sucessão de Yoshimasa ocorreu porque em 1464 ele ainda não possuía herdeiros e acabou por convencer seu irmão mais novo, Ashikaga Yoshimi, a abandonar sua vida de monge para ser nomeado seu herdeiro. Contudo, em 1465 nasceu seu primeiro filho, Yoshihisa. Yamana Sōzen aproveitou-se da oportunidade para se opor à família Hosokawa e, juntamente da esposa de Yashimasa, Hino Tomiko, passou a defender Yoshihisa como herdeiro do xogum.

A guerra foi deflagrada em 1467 entre a tropa Leste - que apoiava o clã Yamana - e a Oeste - que apoiava os Hosokawa - e estourou justamente na capital Heian-kyo ${ }^{12}$ (atual Quioto). A disputa acerca da sucessão tornou-se um pretexto para uma busca pela supremacia militar e diversas casas de shugo-daimyō entraram no conflito. Em 1473, tanto Yamana Mochitoyo quanto Hosokawa Matsumoto morreram. Yoshimasa nomeou seu filho Yoshihisa xogum. A guerra, contudo, não acabara. Ao fim não houve vitoriosos. Os exércitos simplesmente cessaram suas campanhas em 1477 pela exaustão.

Nesse momento, a maioria dos shugo-daimyō já havia deixado a capital e retornado para as suas províncias para ali consolidar suas forças. A capital já não era mais uma fonte de poder para eles. Essa foi, sem dúvida, a maior consequência desta guerra: o poder se fragmentou e o Bakufu perdeu bastante seu poder de governo sobre grande parte do território nipônico.

Quando os shugo-daimyō retornaram às suas províncias, no entanto, muitos tiveram que enfrentar seus vassalos que ali ficaram durante a guerra. Sob tais circunstâncias nem todos conseguiram manter sua antiga posição. Esse foi o maior

\footnotetext{
${ }^{12}$ Em português: "capital da paz".
} 
impulso para o surgimento dos chamados sengoku-daimyō que se contrapunham ao shugo-daimyō principalmente por sua autoridade e legitimidade não provir do Bakufu (não eram nomeados pelo xogum), mas da sua habilidade em exercer o poder e manter o controle sobre os outros kokujin e comunidades de camponeses. Em muitos casos os sengoku-daimyō eram provenientes das antigas casas de shugo-daimyō, mas também houve casos em que eram provenientes de antigos shugo-dai, kokujin, dentre outros.

Tal instabilidade política, na qual o poder não era assegurado por qualquer instituição nacional e diversas famílias perderam ou ganharam enorme poder, é caracterizada pelo fenômeno gekokujō (下克上). Tal conceito pode ser traduzido livremente como "os de baixo suplantando os de cima". Não se trata exatamente de uma revolução social, como tal tradução pode acabar sugerindo, mas expressa não apenas a instabilidade política do momento como também a insegurança causada.

A autoridade central, a partir de então, passou a ser desafiada por grupos e comunidades que queriam autonomia para lidar com questões locais. A prova disso foi a formação de ligas, tanto religiosas, como a Lótus ou $I k k \bar{o} I k k i^{13}$, quanto laicas. Uma forma de resistência popular, tais ligas podiam ser formadas por agricultores (dō-ikkie tokusei-ikki) - as quais reivindicavam diminuição de impostos e cancelamento de dívidas -, por kokujin (kuni-ikki) - que protegiam as propriedades contra invasões e muitas vezes impediam qualquer poder central de interferência -, ou também por seguidores da seita budista jodō-shin (ikkō-ikki) - inicialmente formadas para combaterem outras seitas, passaram, na segunda metade do século XVI, a se posicionar contra os sengoku-daimyō da região de Kaga e Ishikawa. ${ }^{14}$

Essa maior inclinação à autoridade local também pode ser depreendida do crescimento das aldeias autônomas sō, surgidas nos séculos XII e XIV. Tais aldeias funcionavam através do trabalho coletivo nos arrozais cultivados nas terras comuns. Elas possuíam uma administração própria que incluía leis próprias para sua administração (son-pō), uma organização policial com patrulhamento contra invasões (jige-ketsudan) e até uma organização que realizava rituais (miyaza).

\footnotetext{
${ }^{13}$ Ikki pode ser traduzido por "liga". A tradução literal é "uma mente/opinião", mas o termo refere-se a associações reunidas para determinados propósitos, na qual todos os participantes possuíam uma voz.

${ }^{14}$ TSANG, Carol Richmond. The Development of Ikkō Ikki, 1500-1570. Tese (doutorado em História e Línguas Asiáticas Orientais), Universidade de Harvard, 1995.
} 
Neste contexto, os incipientes sengoku-daimyō, a fim de evitar qualquer distúrbio, reconheceram a necessidade de se adaptar também às demandas dos camponeses e se declararam protetores de todas as classes dentro de seus domínios. Estabeleceram acordos com as $d \bar{o}-i k k i$, que passaram a pagar determinadas quantias aos daimyō que por sua vez não permitiam em seus domínios a entrada dos jizamurai samurais coletores que exerciam controle fiscal e judicial sobre as vilas agricultoras. Aproveitaram também para reforçar as relações com todos os bushi residentes, ao alistar todos os líderes na sua própria administração rural. Além disso, acabaram por forçar todos os samurais rurais a abdicar de suas relações com a terra e com o campesinato e mudar-se para o castelo onde residiriam como membros de sua guarnição militar. A estes samurais a saída foi escolher entre abandonar a espada ou a terra. Já para os daimyō ficava a segurança de ter tirado a classe militar do campo, uma medida bastante efetiva contra futuras revoltas. É sintomático que a maior parte dos samurais escolheu por abandonar a terra. ${ }^{15}$

Contudo, embora essas mudanças estivessem ocorrendo nas províncias, seu verdadeiro impacto não alcançou a capital antes da metade do século XVI. A capital e as terras agriculturáveis que a cercavam, formavam uma região central que manteve sua própria configuração nesse período.

Além disso, o Bakufu mesmo estando em declínio e tendo perdido muito de sua governabilidade, ainda tinha um papel político a desempenhar e permaneceu com sua legitimidade reconhecida. Apesar de alguns xoguns não terem poder pessoal algum, a família Hosokawa, que monopolizara o posto de kanrei a partir do início do século XVI, manteve certa estabilidade na região da capital.

Assim, quando os primeiros europeus pisaram em solo japonês em 1542, a situação era de grande instabilidade. O Muromachi Bakufu, que jamais conseguira se impor absolutamente sobre todo o território, ruía a cada ano. No entanto, isso facilitou, de certa forma, a entrada e receptividade dos estrangeiros. Os daimyō do Japão ocidental (local onde os portugueses aportaram e estabeleceram relações comerciais posteriormente) temiam pela sua independência e manutenção e perceberam que

\footnotetext{
${ }^{15}$ HALL, John Whitney. Japan's Sixteenth-Century Revolution. In: ELISON, George e SMITH, Bardwell L. (Ed.). Warlords, Artists and Commoners - Japan in the Sixteenth Century. Honolulu: University of Hawai Press, 1981.
} 
poderiam aumentar sua riqueza e poderio através do comércio exterior e também da importação de produtos trazidos pelos portugueses como armas de fogo e pólvora ${ }^{16}$.

\section{Fim do Muromachi e Período Azuchi Momoyama}

Em 1560, um general começou a se destacar no cenário nacional: Oda Nobunaga (1534-1582). Proveniente da província de Owari ${ }^{17}$, foi neste ano que Nobunaga tornouse o mais poderoso daimyō de sua província após vencer poderosos senhores da região, juntamente de um número reduzido de aliados.

Nesse momento, o agrupamento de daimyō em ligas regionais já virara uma realidade no Japão e chegara a tal ponto de maturidade que a conquista do arquipélago por um deles passou a ser uma possibilidade concreta. Tais coalizões entre daimyō eram baseadas em relações de vassalagem e provavam ser absolutamente eficazes e poderosas. A liga de Nobunaga iniciara-se pequena, mas graças à habilidade militar do líder, assim como a localização estratégica de sua província de origem, foi ganhando considerável proeminência no cenário nacional.

É nesse período também que a crise começara a chegar à capital. O mesmo grupo que expulsara o kanrei Hosokawa Ujitsuna no ano de 1560, assassinou o xogum Ashikaga Yoshiteru em 1565 e o substituiu por Yoshihide. O outro potencial sucessor, Ashikaga Yoshiaki, naquele momento um monge budista, escapou para o oeste em busca de apoio para sua causa. Yoshiaki conseguiu o apoio de ninguém menos que Oda Nobunaga. Conseguiram entrar em Quioto em 1568 e, assim que ganharam o controle da cidade, Yoshihide fugiu e o imperador Ōgimachi nomeou Yoshiaki xogum. Apesar de seu poder político praticamente nulo o imperador ainda era o único capaz de dar legitimidade ao xogum (era ainda sua função a nomeação dos xoguns).

Nobunaga não assumiu nenhum posto. Yoshiaki ofereceu o cargo de kanrei, mas ele não o aceitou. Tal negação não significou, entretanto, que ele queria se isentar do poder central. Seus atos posteriores revelaram sua intenção de transformar a autoridade do xogum em pouco mais que um depositário de rituais da Corte ${ }^{18}$. Yoshiaki, contudo,

\footnotetext{
${ }^{16}$ SANSOM, George Bailey, The Wester World and Japan: a study in the interaction of European and Asiatic cultures, First Tuttle Edition, 1977.

${ }^{17}$ Província considerada estratégica por se localizar próxima à Kinai - local de maior produtividade agrícola do Japão e seu centro político - mas ao mesmo tempo se manter relativamente independente do poder central exercido pelo Bakufu e pelas instituições religiosas.

${ }^{18}$ ASAO, Naohiro, The Sixteenth-century Unification, In: HALL, John W. (ed.). The Cambridge History of Japan, Vol. IV, Nova York, Cambridge University Press, 1991.
} 
percebeu tal manobra e, apostando na sua autoridade e legitimidade como xogum, convocou todos os daimyō do país para derrubar Nobunaga. De 1570 a 1573, o general e seus aliados enfrentaram Yoshiaki e os daimyō que atenderam a seu chamado. Neste último ano, a guerra terminou a favor de Nobunaga que expulsou Yoshiaki da capital e declarou o fim do Muromachi Bakufu. Como forma de legitimação da nova ordem política ele fez com que o imperador mudasse o nome da era para Tenshō (1573-1592). A historiografia denomina o período seguinte (1573-1600) de Azuchi-Momoyama ${ }^{19}$.

Em 1576, iniciou-se a construção do castelo de Azuchi, ordenado por Nobunaga. Construído na província de Ōmi, às margens do lago Biwa - próximo o suficiente de Quioto para que ele pudesse monitorar a capital - o castelo, terminado somente em 1579, possuía um formato jamais visto no Japão até então. Sua estrutura era de madeira, mas ficava sobre uma base de mais de dois metros de pedra. Acredita-se que isso provavelmente tenha sido uma influência européia ${ }^{20}$. Este também foi o primeiro castelo japonês a possuir uma alta torre central.

Nobunaga, após derrotar Yoshiaki, continuou as guerras de unificação. Muitos daimyō não se submeteram a ele, mesmo após sua entrada na capital e capitulação do último xogum Ashikaga ${ }^{21}$. Ele também encontrou resistência por parte de vários monastérios budistas (particularmente os das seitas Shingon e Ikkō).

Oda Nobunaga, contudo, antes de terminar sua obra acabou assassinado juntamente de seu filho mais velho, Oda Nobutada, numa traição de um de seus generais, Akechi Mitsuhide, em 1582, durante uma de suas campanhas militares. Neste momento, quase a metade das províncias estava sob seu poder - vinte e nove das sessenta e seis e mais parcelas significativas de outras duas - sendo estas as mais importantes estrategicamente, uma vez que se encontravam agrupadas perto da capital ${ }^{22}$. Sua posição, no entanto, não era inexpugnável.

Gênio militar, Nobunaga soube melhor que ninguém tirar proveito de tudo que o ocidente trouxera ao Japão naquele momento. Se, por um lado, favoreceu os jesuítas na divulgação da nova doutrina, procurando com isso abalar o poder alcançado por alguns

\footnotetext{
${ }^{19}$ Referência aos castelos construídos por Oda Nobunaga e seu sucessor Toyotomi Hideyoshi.

${ }^{20}$ SANSOM. George B., Japan: a short cultural history, Charles and Tuttle, 1983.

${ }^{21}$ Ashikaga Yoshiaki apesar de ter sido expulso da capital não abdica de seu posto de imediato. Só o faz em 1588, anos depois da morte de Nobunaga.

${ }^{22}$ ELISON, George. The Cross and the Sword: Patterns of Momoyama History. In: ELISON, George e SMITH, Bardwell L., op. Cit.
} 
monastérios budistas, por outro, conseguiu se ajustar perfeitamente ao novo estilo de guerra provocado pela introdução das armas de fogo no Japão. Morto pela traição de Mitsuhide, ainda sem poder completar sua obra, conseguiu ainda assim, quebrar o impasse em que o Japão caíra há um longo tempo devido à guerra civil.

Com sua morte, a sucessão ficou em aberto. A princípio alguns nomes como Oda Nobukatsu, seu segundo filho, ou Tokugawa Ieyasu apareciam como prováveis. Foi, contudo, Toyotomi Hideyoshi (1536-1598), um de seus generais de confiança, quem deu o primeiro passo. Assim que soube do assassinato do líder apressou-se em matar Mitsuhide. Logo em seguida venceu importantes batalhas contra o clã Katsuie e mandou construir um castelo em Osaka.

Tokugawa Ieyasu, por sua vez, não se aliou imediatamente a Hideyoshi. Primeiro juntou-se ao filho de Nobunaga, Nobukatsu, mas em 1586, reconhecendo a destreza política e militar de Hideyoshi, decidiu oficializar sua submissão ao novo líder.

Toyotomi Hideyoshi, no entanto, possui uma história ímpar dentre os líderes japoneses. Proveniente de uma família agricultora (não fazia parte da elite guerreira, portanto) do distrito Aichi na província de Owari, deixou sua casa aos dezesseis anos, a procura de um mestre para servir. Depois de juntar-se ao exército de Nobunaga como mero soldado, ascendeu rapidamente e em 1580 já era um de seus principais generais ${ }^{23}$. Antes da sua ascensão, entretanto, não possuía nem ao menos um sobrenome (como todos de família de lavradores).

Hideyoshi continuou a obra de Nobunaga, contudo, mais do que as guerras de unificação, ao tentar subir ao poder, seu maior problema foi assegurar uma legitimidade. ${ }^{24}$ Sua estratégia de legitimação, no entanto, foi a assimilação à Corte imperial. Se, por um lado, procurou propositalmente enaltecer seus "feitos heroicos" de maneira a desviar a atenção dada às suas "origens obscuras", por outro e mais do que isso, apegou-se às tradições japonesas de forma a identificar-se com a instituição que era capaz, melhor do que qualquer uma, de assegurar o modelo de autoridade japonês: a instituição imperial. As tais "origens obscuras", entretanto, era algo que deveria ser

\footnotetext{
${ }^{23}$ ASAO, Naohiro. The Sixteenth-century Unification, In: HALL, John W. (ed.), op. cit., p. 45-46.

${ }^{24}$ ELISON, George. Hideyoshi, the Bountiful Minister. In: ELISON, George e SMITH, Bardwell L., op. Cit., p. 224.
} 
"superado" de alguma forma no processo de construção de legitimidade do poder de Hideyoshi.

Investindo nessa estratégia ele iniciou seu processo de aristocratização logo após a morte de Nobunaga. Mais precisamente durante os preparativos para o suntuoso funeral do falecido líder. O primeiro posto na corte foi alcançado em novembro de 1582, como General dos Guardas do Palácio da Esquerda (sakon no e no shōshō). A partir de então foi subindo na hierarquia cortesã até ser adotado por Konoe Sakihisa da linhagem dos Fujiwara - família que há séculos monopolizara o posto de kan'paku ${ }^{25}$, o mais alto na hierarquia da Corte depois do imperador. Em 1584, ele mesmo foi nomeado kan'paku. Contudo, a adoção por Sakihisa, assim como a "linhagem emprestada", apesar de terem quebrado certos impasses, acabavam por servir como expositores do verdadeiro passado de Hideyoshi. Percebendo isso o líder conseguiu da Corte imperial, em outubro de 1585, seu famoso nome: Toyotomi.

A escolha pela legitimação através da aproximação com a instituição imperial não era, contudo a única opção. Hideyoshi possuía outra, sendo talvez o caminho mais óbvio tentar tornar-se xogum, uma instituição que possuía dois séculos e meio de tradição de um sistema legal no Japão. O líder teve que lidar com o fato de que Ashikaga Yoshiaki, último dos xoguns do Muromachi, manteve-se até 1588 (ano em que finalmente abdica do cargo) fora de seu controle. Apesar de Nobunaga ter vencido a guerra e o expulsado de Quioto em 1573, Yoshiaki fugiu e não abdicou do cargo até 1588.

A tese de que Hideyoshi não se tornara xogum por falta de parentesco com a linhagem imperial é contestada por alguns historiadores, como George Elison, que afirmam que para um líder astuto como ele, produzir uma genealogia que o ligasse aos Minamoto, assim como o fez seu sucessor Tokugawa Ieyasu, não seria grande problema. $^{26}$

\section{O fim da reunificação}

Após longas campanhas contra poderosos inimigos Hideyoshi terminou a unificação, em 1590. Antes disso, como líder reconhecido pela maior parte da classe guerreira e como kan'paku, baixou diversos éditos de crucial importância para

\footnotetext{
${ }^{25}$ Espécie de conselheiro do imperador.

${ }^{26}$ ELISON, George. Hideyoshi, the Bountiful Minister. In: ELISON, George e SMITH, Bardwell L., op. Cit., p. 230.
} 
compreensão do período seguinte. Um desses éditos foi o de expulsão dos missionários cristãos, baixado em 1587, que discutiremos melhor mais à frente. Outro importante de ser citado foi do katana-gari, ou seja, caça à espada, que proibia todos que não fossem samurais (membros da classe guerreira) a portar espadas, o que demarcava ainda mais a separação entre agricultores e samurais. Apesar do tom autoritário do édito, o mesmo foi colocado como uma medida que visava o bem geral, inclusive dos agricultores. E não se pode negar que a população rural também tenha se beneficiado da medida, uma vez que a mesma ajudou na pacificação do campo, o que tornou possível a instalação de um sistema de administração local que permitiu uma expansão considerável dos recursos. ${ }^{27}$ Em 1588, ele ainda proibiu a pirataria e ordenou que todos os daimyō cessassem o comércio privado, numa tentativa de colocar o poder central como portador do monopólio do comércio exterior.

Outra importante atuação de Hideyoshi foram os levantamentos cadastrais (taiko kenchi), iniciados em 1584. Estes foram os mais minuciosos feitos até então. Além disso, através deles foram introduzidos métodos mais eficazes de medida da terra e $\operatorname{taxação~}^{28}$. Tais cadastramentos ainda representaram o último passo para a mudança na legislação acerca da posse da terra, pois a partir do período Muromachi a Corte deixou de dar legitimidade à posse da terra - somente o xogunato o poderia fazer. Contudo, nos casos de negação por parte do xogunato, largas porções de terra ficavam sem uma autoridade coerciva superior. Com esses cadastramentos, as terras foram melhor catalogadas, de forma a não deixar grandes porções de terras agriculturáveis sem um dono.

Os cadastramentos taikō kenchi são absolutamente importantes também porque se tornaram a base sobre a qual o status legal de samurais e camponeses se fixou nos próximos dois séculos e meio. A verdadeira separação legal entre a classe militar e agricultora baseou-se justamente nestes cadastramentos. ${ }^{29}$

Após completar a unificação do Japão, Hideyoshi não cessou suas campanhas. Em 1591, ordenou aos daimyō que reunissem tropas para serem enviadas à Coréia. Decidiu invadi-la, pois seu monarca, apesar de ter enviado uma comissão de

\footnotetext{
${ }^{27}$ HALL, John Whitney. Japan's Sixteenth-Century Revolution. In: ELISON, George e SMITH, Bardwell L. (Ed.). op. Cit, pag. 15.

${ }^{28}$ ASAO, Naohiro. The Sixteenth-century Unification, In: HALL, John W. (ed.), op. cit.

${ }^{29}$ HALL, John Whitney. Japan's Sixteenth-Century Revolution. In: ELISON, George e SMITH, Bardwell

L. (Ed.). op. cit., pag. 16.
} 
embaixadores para congratulá-lo pela vitória, recusou-se a pagar tributo a ele como sinal de submissão. Além disso, Hideyoshi intencionava invadir a China, aproveitandose da crise enfrentada pela dinastia Ming ${ }^{30}$. Contudo, para tanto precisaria passar com seu exército pela Coréia, cujo soberano era vassalo do imperador chinês. O líder japonês chegou a pedir autorização para tal empreitada ao monarca coreano, mas diante da negação do mesmo montou uma expedição (cerca de duzentos mil homens) ${ }^{31}$ e partiu para a Coréia em 1592.

Não é tão simples compreender as razões para tamanha empreitada, uma vez que o país acabara de ser reunificado à custa de mais de um século de guerras intestinas. Contudo, é preciso lembrar-se da grande dificuldade que Hideyoshi enfrentou para legitimar-se no poder. As dinastias que lideraram a classe guerreira (buke) até então - os Minamoto durante o Kamakura Bakufu e os Ashikaga durante o Muromachi - possuíam relações de parentesco com os Taira, descendentes do clã imperial. Este, por sua vez, desde que se instituíra no poder - oficialmente no século VII a.C. - jamais saíra ${ }^{32}$. A única dinastia imperial, a dinastia Yamato, possuiria, segundo crenças nativas, parentesco com os deuses, portanto seriam eles próprios divinos.

Dessa maneira, a ascendência era de total importância para a legitimação de um líder no poder. Apesar de importantes historiadores sobre o período negarem que Hideyoshi não tenha se tornado xogum por falta de parentesco com a família real, vimos que a estratégia adotada pelo líder foi outra. Para Asao Naohiro ele:

(...) ofereceu uma nova interpretação para o posto de regente imperial [kan'paku]: do seu ponto de vista era um cargo que deveria conquistar o reino. Para Hideyoshi as invasões do continente foram compelidas, em parte, pela necessidade de firmar sua autoridade. $^{33}$

A guerra com a Coréia iniciou-se em 1592. Os coreanos, por sua vez, receberam ajuda do império Ming. No ano seguinte foi declarado um armistício e as negociações de paz seguiram-se pelos próximos quatro anos. Em 1596, chegou uma embaixada

\footnotetext{
${ }^{30}$ Dinastia que governou a China de 1368 a 1644. Substituiu a antiga dinastia Yuan e foi sucedida pela dinastia mongol Qing, também chamada de Manchu.

${ }^{31}$ SANSOM. George B., op. cit., (1997).

32 Diversos historiadores contemporâneos rejeitam essa tese afirmando que trata-se apenas de uma construção histórica afim de legitimar o clã imperial. Contudo, independente da veracidade ou não dos fatos, esse é e sempre foi o discurso oficial.

${ }^{33}$ ASAO, Naohiro, The Sixteenth-century Unification, In: HALL, John W. (ed.), op. cit., p. 85 (tradução minha).
} 
chinesa e coreana ao Japão oferecendo o reconhecimento de Hideyoshi, pelo império Ming, como "rei" do Japão. As negociações falharam, contudo, e o líder ordenou uma segunda invasão em 1597.

Em meio a essa segunda invasão, Hideyoshi faleceu inesperadamente em setembro de 1598. Tokugawa Ieyasu e seus aliados decidiram manter sua morte em segredo até o fim das negociações para a retirada do exército japonês. O Japão terminou a guerra sem qualquer ganho e pelos dois séculos seguintes a dinastia que governou o país, os Tokugawa, abandonou qualquer ambição de conquistas no estrangeiro a favor de uma maior estabilidade interna.

Com a morte de Hideyoshi, mais uma vez a disputa pelo poder se abria. Ieyasu não declarou de imediato sua intenção de suceder como novo líder da classe guerreira, mas começou a agir rapidamente firmando alianças com poderosos daimyō através de casamentos. O filho de Hideyoshi, Toyotomi Hideyori, possuía apenas cinco anos no ano da morte de seu pai, mesmo assim muitos apoiavam a permanência do clã Toyotomi no poder.

Em 1600, o país estava dividido entre aqueles que apoiavam Ieyasu e os que apoiavam Hideyori. O destino político do arquipélago foi decidido na famosa batalha de Sekigahara em outubro de 1600. Conta-se que tal batalha, altamente mortífera para ambos os lados, durou apenas seis horas ${ }^{34}$. A vitória ficou ao lado de Ieyasu que, logo em seguida, preocupado em assegurar seu poder, confiscou as terras de 87 daimyō aliados dos Toyotomi e as distribuiu entre seus aliados. Ele também transferiu de local mais 43 daimyō, além de criar novos. ${ }^{35}$

Hideyori, por sua vez, permaneceu no castelo de Osaka com sua mãe, Lady Yodo, aos cuidados de Mori Terumoto. Ieyasu, apesar de ter confiscado dois terços das terras do clã Toyotomi se sentiu compelido a obedecer ao juramento que fizera à Hideyoshi, ao menos por hora, e não invadiu o castelo de Osaka.

Em 1603, o imperador Go-Yozei nomeou Ieyasu sei-i tai-shogun (xogum). Este já havia se antecipado a isso e em 1600 providenciara uma genealogia que o colocava como descendente da linhagem dos Minamoto (descendentes do clã imperial). Há

\footnotetext{
${ }^{34}$ YAMASHIRO, José. Japão - Passado e presente, Editora Hucitec, São Paulo, 1978.

${ }^{35}$ ASAO, Naohiro, The Sixteenth-century Unification, In: HALL, John W. (ed.), op. cit., p. 60.
} 
muitas dúvidas acerca da veracidade de tal documento. Contudo, no Japão pré-moderno tal comprovação era necessária, como pudemos constatar ao analisar o caso de Hideyoshi, ainda que fosse forjada.

Ieyasu fazia parte do clã Matsudaira, da província de Mikawa. Contudo, em 1566 pediu à Corte de Quioto para reconhecer a mudança de sobrenome para Tokugawa, nome de uma vila na província de Kōzuke, local de onde sua família, oito gerações antes da sua, teria supostamente vindo ${ }^{36}$.

Diferente dos seus antecessores - Hideyoshi e Nobunaga - Ieyasu acabou por tornar-se xogum. Desta forma, como resultado de determinadas escolhas e oportunidades, foi capaz de perpetrar, melhor que seus antecessores, a ordem construída no breve período Azuchi-Momoyama. Contudo, é inegável que foi Nobunaga e Hideyoshi que edificaram a ordem que Ieyasu e seus sucessores Tokugawa puderam lapidar e traduzir, durante toda a era Edo, à sua maneira.

O Estado que erigiram caracterizava-se pelo pressuposto de uma hegemonia militar imposta a todos os grupos de guerreiros. Foi um Estado imposto, não proveniente de um clamor por parte dos daimyō. Não se pode dizer, entretanto, que estes não ganharam nada com a formação desse Estado. Ao mesmo tempo em que tiveram que abrir mão de parte da autonomia e autoridade sobre seus domínios e o povo que nela vivia, tiveram sua posição assegurada por um poder central e não mais precisariam impor-se às custas de um exército próprio. Para o historiador John W. Hall, assim como todas as grandes revoluções institucionais da história japonesa (ele cita a reforma Taika do século VII e a Restauração Meiji do XIX), a revolução do fim do século XVI foi alcançada como resultado de um acerto entre comandantes e comandados - penso aqui que uma vez que o autor fala em "revolução institucional", os "comandados" em questão tratar-se-iam da elite submetida ao pequeno grupo que exercia o poder de facto - entre um esforço para controlar e um esforço para resistir a esse controle. ${ }^{37}$

A unificação japonesa, em suas palavras:

\footnotetext{
${ }^{36}$ HALL, John W., The Bakuhan System, in: HALL, John W. (ed.), op. cit. (1990).

${ }^{37}$ HALL, John Whitney. Japan's Sixteenth-Century Revolution. In: ELISON, George e SMITH, Bardwell L. (Ed.). op. cit, pag. 9.
} 
(...) não foi simplesmente uma questão de conquista por parte de um poderoso daimyō.

Pelo contrário, a unificação está mais para um desenvolvimento universal, isto é, o estabelecimento da classe guerreira (os bushi ou samurais) como a primeira autoridade governante no país. ${ }^{38}$

Este é, com certeza, a principal característica que marcará a história do Japão a partir de então até a restauração Meiji, em 1868. A aristocracia militar, que desde 1192 - ano em que Minamoto Yoritomo foi nomeado como o primeiro xogum da história do Japão - procurava abocanhar o poder através da criação de um governo militar (Bakufu), jamais atingira tamanho controle como na era Edo.

Nos períodos Kamakura e Muromachi não apenas o xogum, mas também os nobres (kuge) e o imperador estabeleciam relações com a classe guerreira e podiam ceder postos e cargos na Corte. ${ }^{39}$ Isso teria seu fim logo no início do governo Tokugawa que passou a controlar todas as visitas ao imperador e sua Corte e definiu, através do decreto de 1615, kuge shohatto, as atividades do tenno ${ }^{40} \mathrm{e}$ dos kuge, assim como a nomeação e demissão de funcionários na Corte, dentre outras coisas.

Contudo, a revolução do Azuchi Momoyama possui duas facetas: ao mesmo tempo em que estabeleceu a classe guerreira como primeira autoridade do país, promoveu ao status de samurai um significativo segmento da população rural (no período Tokugawa, a classe samurai atingiu notáveis $7 \%$ da população ${ }^{41}$ ) e pode ser considerada, portanto, uma revolução pró-samurai. No entanto, ao mesmo tempo em que os unificadores expandiram os direitos e privilégios do governo samurai também o obrigou a assumir uma maior responsabilidade social. Ao reconhecer certos privilégios do autogoverno popular deram ao campesinato e à burguesia em formação novas áreas de autonomia. O resultado foi uma combinação de absoluto domínio exercido sobre as unidades de administração sendo que dentro destas foi dada aos japoneses de cada classe a proteção de esferas definidas de existência.

\footnotetext{
${ }^{38}$ HALL, John W., Introduction, in: ibidem, p. 5 (tradução minha).

${ }^{39}$ ASAO, Naohiro, The Sixteenth-century Unification, In: HALL, John W. (ed.), op. cit.

${ }^{40}$ Soberano dos céus, em japonês. Refere-se ao imperador.

${ }^{41}$ HALL, John Whitney. Japan's Sixteenth-Century Revolution. In: ELISON, George e SMITH, Bardwell L. (Ed.). op. cit, pag. 13-14.
} 


\section{Uma nova ordem social}

As mudanças promovidas por Nobunaga e Hideyoshi não afetaram apenas as elites militar e civil. Como se pode depreender do que foi dito acima, agricultores, mercadores e artesãos, mesmo que pequenos, foram também profundamente afetados.

Assim que ascendeu como principal autoridade guerreira, Nobunaga se declarou o único capaz de proteger a todos os camponeses, que tanto sofriam com a exploração dos daimyō e outras autoridades locais. Ele implantou uma política que incluiu a construção de diversas cidades castelo, estabelecimento de mercados (rakuichi) e grêmios livres ( $r a k u z a$ ), destruição de alguns pedágios, introdução de algumas técnicas da medicina ocidental, menor carga tributária sobre os agricultores que passaram a pagar o imposto não mais ao senhor, mas às unidades provinciais. ${ }^{42}$

O incentivo ao comércio foi grande e fazia parte da sua estratégia (também utilizada posteriormente por Hideyoshi) para ocupar cidades-castelo recém-formadas ou até construir novas. O arquipélago japonês passou por um boom de construções urbanas sem precedentes que durou até meados do século XVII. ${ }^{43}$

A construção de tais cidades - juntamente com os éditos baixados por Hideyoshi, como o katana gari ou a proibição da pirataria, e o levantamento cadastral taiko kenchi - deu corpo ao sistema de status conhecido em japonês como shi-nō-kō$s h \bar{o}$, em português guerreiro-camponês-artesão-mercador, que prevaleceu na Era Edo. Tal sistema não incluía importantes setores da sociedade japonesa como os aristocratas kuge, religiosos, artistas, dentre outros. Contudo, serviu para demarcar bem a separação entre determinadas classes, principalmente entre guerreiros samurais (classe militar) e o resto.

Além disso, tais decretos, assim como a supressão das ligas $I k k i$ - iniciada por Nobunaga e finalizada com Hideyoshi - apontam para uma nova tendência da sociedade japonesa, que irá se institucionalizar apenas em Edo, de cessão das guerras particulares entre daimyō. Para Naohiro Asao, "serviam como contribuição final para a tendência da sociedade dos séculos XVI e XVII a abandonar a prática de resolver disputas entre os diversos grupos através do recurso às [próprias] armas". 44

\footnotetext{
${ }^{42}$ ASAO, Naohiro, The Sixteenth-century Unification, In: HALL, John W. (ed.), op. cit.

${ }^{43}$ Ibidem.

${ }^{44}$ Ibidem, p. 50 (tradução minha).
} 


\section{Era Edo - Governo Tokugawa}

A Era Edo iniciou-se oficialmente com a nomeação de Ieyasu para sei-i tai shogun em 1603. Seu poder, contudo, não estava completamente assegurado. Embora ele tivesse vencido o clã Toyotomi e seus aliados em Sekigahara três anos antes, Hideyori sobrevivera e vivia com sua mãe, Lady Yodo, no castelo de Osaka, que abrigava também antigos daimyō que perderam tal status após a batalha.

Em 1605, Ieyasu abdicou do cargo de xogum em favor de seu filho Tokugawa Hidetada, adotou o título de ōgosho (xogum aposentado) e retirou-se para o castelo de Sun'pu, enquanto Hidetada permaneceu na residência de Quioto. Tal estratégia garamtiu que a sucessão de Ieyasu ficasse nas mãos de um Tokugawa e estabeleceu um precedente de sucessão direta para o cargo de xogum nessa nova era. Assim, Ieyasu foi o único dos três unificadores do Japão que conseguiu construir uma ordem que transcendesse a sua própria pessoa.

No inverno de 1614, atormentado com a possibilidade de Hideyori - que àquela altura estava com 21 anos - derrubar os Tokugawa, Ieyasu promoveu o primeiro ataque ao castelo de Osaka. Hideyori não conseguiu o apoio de nenhum daimyō de fora do castelo. Contudo, aqueles que se abrigaram em seu castelo após Sekigahara, alguns deles cristãos, conseguiram repelir o ataque de Ieyasu. Estima-se que foram cerca de noventa mil defensores contra uma força duas vezes maior, munida de armas de fogo recém-adquiridas dos europeus. ${ }^{45}$

Percebendo que poderia perder a guerra, apesar da situação vantajosa, Ieyasu propôs uma trégua. Contudo, numa estratégia para surpreender Hideyori e seus aliados, promoveu um novo ataque, em maio de 1615, que destruiu completamente o castelo de Osaka. Hideyori e sua mãe cometeram suicídio ao fim da invasão, acabando por completo com a linhagem dos Toyotomi, assim como qualquer ameaça de peso contra os Tokugawa.

Não por isso Tokugawa Hidetada teve qualquer facilidade em ser reconhecido como maior liderança dentre a classe guerreira. As principais medidas que o ajudaram a consolidar-se como líder de Estado foram aquelas que regulavam o relacionamento com as nações estrangeiras, principalmente as européias. Hidetada adotou um discurso antiestrangeiro e clamou ser o único capaz de proteger o Japão destes.

\footnotetext{
${ }^{45}$ HALL, John W., The Bakuhan System, in: HALL, John W. (ed.), op. cit. (1990).
} 


\section{A importância do comércio nas relações entre o Japão e o Ocidente}

O comércio ultramarino era essencial para o Japão, uma vez que se trata de um arquipélago. Seu comércio com a China e a Coréia remonta há muitos séculos atrás, contudo, o comércio oficial com a corte Ming foi de 1405 a 1523. Neste último ano, o comércio cessou graças a uma violenta briga ocorrida no porto chinês de Ningbo na qual membros do clã japonês Ōchi cometeram crimes contra pessoas e propriedades chinesas. O governo chinês declarou então o acordo comercial com o Japão terminado. ${ }^{46}$

Sob a pressão japonesa, no entanto, o governo Ming cedeu e reatou o acordo. Entretanto, ambos os reinos passavam por problemas internos graves e pouco fizeram para retomar o comércio que já possuía diversas restrições. Algumas missões foram trocadas esporadicamente até 1548 , ano em que a última missão japonesa foi autorizada a seguir até Pequim.

O comércio ilegal, contudo, só aumentou a partir de então. Os grandes agentes deste eram os chamados wakō, piratas japoneses. No início do século XVI, a ação desses piratas aumentou de tal forma que ficara extremamente perigosa a rota entre China e Japão. Algumas províncias litorâneas chinesas eram atacadas quase que anualmente. Assim sendo, a corte Ming cessou completamente seu comércio com o arquipélago nipônico. Há relatos, contudo, de que os Ming, já em 1373, haviam mandado ao Japão dois monges para reclamar da ação dos wako. ${ }^{47}$

Os portugueses, por sua vez, desde 1511 haviam instalado uma feitoria em Malaca $^{48}$. De lá iniciaram, na década de 1520, um comércio informal com os chineses. Não o oficializaram, pois as tentativas de acordo com as autoridades Ming fracassaram. Os principais produtos trocados eram especiarias, madeiras aromáticas, porcelanas, sedas e caixas de cobre. ${ }^{49}$

Em 1542, três portugueses comerciantes que participavam desse comércio em Malaca tiveram sua pequena embarcação conduzida por um tufão até a ilha japonesa de

\footnotetext{
${ }^{46}$ SANSOM, George B., History of Japan: 1334-1615, Tóquio: Charles and Tuttle, 1990.

${ }^{47}$ SEABRA, Leonor Diaz de. Macau, a China e o Japão: Uma relação histórica - séculos XVI-XVII. Revista de Cultura, Macau, $\mathrm{n}^{\circ}$ 6, 2003.

${ }^{48}$ SUBRAHMANYAM, Sanjay, O Império Asiático Português 1500-1700, tradução Paulo Jorge Sousa Pinto, Portugal: Difel, 1993.

${ }^{49}$ LOUREIRO, Rui Manuel. Navios, Mercadorias e Embalagens na Rota Macau-Nagasáqui. Revista de Cultura, Macau, no 24, 2007.
} 
Tanegashima. Lá foram recebidos pelos nativos que os ajudaram a retornar para Malaca. Pela primeira vez na história, um europeu relatava ter pisado em solo japonês.

Pouco tempo depois do acontecimento, já em 1545, navios portugueses passaram a frequentar os portos da ilha japonesa de Kyushū para comercializar produtos trazidos, em sua maioria, do continente asiático. A partir de 1550, as autoridades chinesas os autorizaram a usar o porto da ilha de Shangchuan e frequentar as feiras mercantis de Cantão duas vezes por ano. Dessa forma, os portugueses podiam trazer produtos chineses de grande demanda no Japão como a seda, porcelanas e ouro. Em troca, traziam do arquipélago basicamente prata, uma vez que a prata japonesa era de melhor qualidade e mais barata que a produzida no continente.

Em 1550, percebendo o quão lucrativo tal comércio era, a Coroa lusitana decidiu assumir seu monopólio. A partir de então, passou a controlar todo o comércio existente entre Goa, Malaca, Macau e Japão.

Os chineses, por sua vez, perceberam que tal comércio se mostrava benéfico para eles também. Isso porque ajudava as economias locais e reforçava a segurança nas regiões costeiras contra os wako, uma vez que os navios portugueses eram fortemente armados. Assim, em 1557, autorizaram-nos a utilizar também o porto de Macau em troca do pagamento de direitos alfandegários.

A embarcação utilizada pelos portugueses nesse comércio com o Japão ficou conhecida pelo nome de Nau do Trato. Era uma enorme embarcação mercantil que geralmente era seguida nas suas viagens de pequenas embarcações chinesas como juncos, somas ou chós. Os galeões eram também utilizados, mas estes transportavam mais artilharia, produto também comercializado no Japão. ${ }^{50}$

Em 1600, o comércio português na costa nipônica passou a ser ameaçado pela chegada dos holandeses. Em dois anos foi fundada a Companhia Holandesa das Índias Orientais $^{51}$ e, em 1609, eles ganharam autorização para abrir uma feitoria em Hirado. Além da concorrência, os portugueses passaram a sofrer também com os ataques holandeses às suas embarcações e ao porto de Macau.

\footnotetext{
${ }^{50}$ Ibidem.

${ }^{51}$ YAMASHIRO, José, Choque Luso no Japão dos Séculos XVI e XVII, São Paulo: Ibrasa, 1989.
} 
A partir de 1618, a Nau do Trato foi abandonada pelos portugueses que passaram a utilizar-se de galeotas - embarcações menores que se utilizavam de velas e remos além de serem mais fáceis de manobrar. Na atual situação, a galeota se apresentava mais vantajosa já que carregava menos mercadorias e caso sofresse algum ataque no caminho a perda não seria tão grande como na Nau do Trato.

\section{A reunificação e o fim do século cristão}

Os comerciantes portugueses, quando chegaram ao Japão em 1545, ficaram confinados aos portos da ilha de Kyushū. Até 1562 utilizaram-se praticamente apenas de Hirado e após 1564 passaram a utilizar os portos da região de Hizen, principalmente o de Nagasaki.

A pacificação conduzida por Nobunaga e posteriormente por Hideyoshi só chegou a Kyushū em 1587, quando o segundo conseguiu invadir a ilha. As famílias que dominavam as principais províncias da região até a invasão eram os Shimazu, Ōtomo e Ōchi.

Os missionários jesuítas, como poderemos ver nos capítulos seguintes, diferentemente dos comerciantes, não se confinaram à ilha de Kyushū. Adentraram-se também na maior ilha (Honshū) até a capital Quioto ${ }^{52}$. Contudo, o maior número de cristãos sempre esteve na ilha de Kyushū.

Os missionários conseguiram diversos favores por parte de alguns daimyō da região de Kyushū e até mesmo converteram alguns deles. Em 1559, o padre Gaspar Vilela foi recebido numa audiência com o xogum Ashikaga Yoshiteru, graças à interferência de um desses daimyō, que escrevera uma carta para um conhecido seu influente em Quioto pedindo tal audiência. ${ }^{53}$

O resultado desse encontro foi bastante benéfico para os missionários uma vez que Yoshiteru baixou um édito de proteção aos missionários, a despeito de toda a pressão que sofreu por parte do clero budista. A partir de então, os jesuítas conseguiram catequizar pessoas importantes residentes na capital, inclusive membros da elite guerreira.

\footnotetext{
${ }^{52}$ Nos documentos ela aparece com o nome de Meaco, ou seja, Miyako, que em japonês quer dizer "capital".

${ }^{53}$ ELISONAS, Jurgis, Christianity and the Daimyō, in: HALL, John W. (ed.), op. cit., (1990).
} 
Em 1580, o primeiro daimyō converso, dom Bartolomeu (Omura Sumitada), doou Nagasaki aos jesuítas. Desde 1563 ele vinha sofrendo ataques de seus vizinhos, principalmente de Ryūzōji Takanobu. Percebendo que não conseguiria resistir por muito tempo, acabou por fazer a doação do porto e suas terras adjacentes em troca de uma quantia anual fixa paga pela Companhia de Jesus além dos impostos cobrados no porto. Para Jurgis Elisonas:

"ao fazer isso, [Bartolomeu] não apenas assegurava que os navios portugueses continuassem a aportar regularmente em Nagasaki (...), mas também salvaguardava para si um substancial fluxo de rendimento proveniente do comércio desses navios". ${ }^{54}$

Oda Nobunaga, por sua vez, manteve também um relacionamento amigável com os missionários. Em 1569, ele recebeu o padre Luis Fróis pela primeira vez graças à intercessão de Takayama Ukon (um daimyō converso da região de Miyako). ${ }^{55}$ Outros encontros entre os padres e Nobunaga ocorreram até sua morte, que inclusive os recebeu no seu castelo de Azuchi.

A hostilidade do líder para com algumas das seitas budistas japonesas especialmente da seita $I k k \bar{o}$, cujos membros, organizados em ligas $I k k i$, resistiram à dominação do líder até sua extirpação final, assim como os seguidores do Honganji que em 1570 firmaram uma coalizão com os daimyō inimigos de Nobunaga - facilitou o caminho dos jesuítas. Ao abrir caminho para uma nova religião, Nobunaga percebia estar também minando o poder político alcançado por alguns monastérios budistas. ${ }^{56}$

Quando Hideyoshi assumiu o poder, manteve o bom relacionamento com os missionários, como seu antecessor. Em 1583, recebeu o superior da missão de Miyako $^{57}$, padre Organtino Gnecchi Soldo, e lhe forneceu um terreno em Osaka para

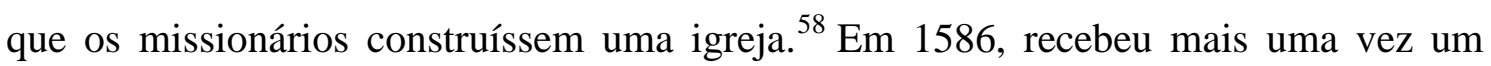

\footnotetext{
${ }^{54}$ Ibid., p. 329 (tradução minha).

${ }^{55}$ SANSOM, George B., op. cit.,(1990)

${ }^{56}$ SANSOM. George B., op. cit., (1997).

${ }^{57}$ A missão no Japão era dividida em três partes: Miyako - correspondente a região da capital - Bungo e Shimo. Cada uma das três partes possuía um superior, que era subordinado ao Superior universal do Japão.

58 JANEIRA, Armando Martins, O Impacto Português sobre a Civilização Japonesa, Lisboa: Publicações Dom Quixote, 1970.
} 
jesuíta, dessa vez foi o então vice-provincial da missão ${ }^{59}$, padre Gaspar Coelho, quem se encontrou com Hideyoshi no seu novo castelo em Osaka.

Os jesuítas foram pegos de total surpresa ${ }^{60}$ quando em julho do ano seguinte o líder baixou um édito de expulsão dos missionários cristãos. Neste, ele afirmava ser o Japão a terra dos deuses (shinkoku) e uma vez que os missionários cristãos negavam tal fato, a pregação de sua doutrina não poderia ser tolerada. $\mathrm{O}$ édito dava vinte dias para que todos deixassem o Japão. Nagasaki, por sua vez, deixou de pertencer à Companhia de Jesus e foi anexada pelo líder às terras públicas.

Não se sabe exatamente quais foram as razões de Hideyoshi para tomar tal atitude nesse específico momento, uma vez que até então ele mantivera um bom relacionamento para com os jesuítas e japoneses conversos. O Édito de expulsão, contudo, contém algumas informações importantes. O próprio uso do termo shinkoku, traduzido por Luis Fróis por "reino de Camis"61 é bastante significativo. Se, por um lado, a adoração aos Kamis era uma prática antiga no Japão, o discurso do "reino (ou terra) dos Kamis" (shinkoku) foi se desenvolvendo justamente nesse período e possui uma relação intrínseca com o Estado em formação.

Nesse momento não existia uma religião independente no Japão denominada shintō (xintoísmo) ${ }^{62}$; o nome referia-se na verdade a um sistema místico de rituais e tabus $^{63}$. As referências a esse sistema, entretanto, vão crescendo juntamente com a formação do Estado japonês dos períodos Azuchi-Momoyama e Edo. A expressão shinkoku, contudo, possui três conotações básicas, segundo o historiador japonês Toshio Kuroda:

1. Os kamis se manifestam no Japão, onde protegem seu território e providenciam orientação religiosa para seus habitantes.

\footnotetext{
${ }^{59}$ Quando Gaspar Coelho assumiu o superiorato da missão no Japão após a saída de Francisco Cabral em 1581, a mesma foi alçada à categoria de vice-província. Portanto, o superior da missão seria, a partir de então, chamado de vice-provincial.

${ }^{60}$ Pelo menos foi o que retrataram nas cartas. Afirmavam que Hideyoshi não dera qualquer sinal de hostilidade antes do Édito.

${ }^{61}$ Em uma carta ao Geral da Companhia, Luis Fróis transcreve o tal Édito de expulsão numa versão traduzida. Luis Fróis. Carta ao geral da Companhia. 20 de fevereiro de 1588. In: GARCIA, José Manuel (ed.). Cartas que os Padres da Companhia de Iesus Escreverão dos Reynos de Iapão e China aos da mesma Companhia da Índia e Europa des do anno de 1549 até o de 1580, vol. II, Maia, Cotovia, 1997, f. $209 \mathrm{v}$.

${ }^{62}$ Kamis seriam entidades exclusivas da religião nativa japonesa, não existiriam, portanto, no budismo.

${ }^{63}$ KURODA, Toshio. The discourse on the 'Land of Kami' (shinkoku) in Medieval Japan.Japanese Journal of Religious Studies, (Tradução Fábio Rambelli), 23/3-4, pp. 353-385.
} 
2. O reino passa a ser uma entidade sagrada, uma vez que a terra, o soberano e o povo teriam sido gerados pelos kamis.

3. O Japão passa a ser caracterizado por determinados costumes religiosos. ${ }^{64}$

Dessa forma, podemos perceber que, embora o conceito seja vago, apresenta uma determinada visão de Estado, que passa a ser diretamente relacionada com o território. Além disso, ponto essencial para entender a utilização do conceito por Hideyoshi, possibilita a sistematização e justificação religiosa da ordem secular.

No entanto, é importante notar que ele é utilizado justamente para qualificar o relacionamento do Japão com outros países. Algo bastante lógico, afinal o Japão só pode ser considerado terra dos kamis uma vez que as outras nações não o são. Nas palavras de Kuroda, ele "funcionou como forma de consciência nacional dentro de uma rede de relações do Japão com outros países". ${ }^{65}$

Portanto, a legitimação do Estado em formação caminhou, durante os séculos XVI e XVII, junto com a regulamentação da relação do Japão com os países estrangeiros. Tenha isso sido feito através de guerras (tentativa de invasão da Coréia) ou de leis e Éditos (sendo que a expulsão dos jesuítas em 1587 foi apenas o primeiro deles).

No édito de 1587, Hideyoshi ainda afirmava que os padres faziam os conversos destruírem os templos dos kamis e hotokes, causando grande alvoroço. Entretanto, ele deixou claro que os navios portugueses poderiam continuar frequentando os portos nipônicos e que todos aqueles que respeitassem a lei dos kamis e hotokes, não apenas os mercadores, tinham liberdade para entrar e sair do Japão quando quisessem. ${ }^{66}$

O último dos artigos, segundo a tradução que temos de Fróis, demonstra uma certa tolerância que realmente foi aplicada. Os padres e irmãos jesuítas, em sua maioria não deixaram o arquipélago, mas passaram a pregar, a partir de então, com mais discrição. Por sua vez, Hideyoshi não ordenou qualquer atitude hostil para com os cristãos, fossem japoneses conversos ou europeus. Em um Aviso, dirigido unicamente aos japoneses (o Édito de 1587 fora dirigido aos estrangeiros), em 23 de julho de 1587 -

\footnotetext{
${ }^{64}$ Ibdem.

${ }^{65}$ Idem, pag. 379. (tradução minha).

${ }^{66}$ Luis Fróis. Carta ao geral da Companhia. 20 de fevereiro de 1588. In: GARCIA, José Manuel (ed.). $O p$. Cit., f. 209v.
} 
um dia antes de o Édito de expulsão ter sido baixado - Hideyoshi afirmava que a conversão ao cristianismo deveria ser de livre escolha do indivíduo. Não podemos interpretar tal artigo, entretanto, como uma defesa da liberdade religiosa. Neste caso, Hideyoshi mirava as conversões forçadas promovidas nos territórios de daimyō cristãos. Ele também colocou no aviso que todos aqueles que possuíssem renda acima de 200 chō deveriam obter permissão oficial para tornarem-se cristãos. ${ }^{67}$

O fato de Hideyoshi ter mantido um bom relacionamento com os jesuítas até a data do Édito pode ser compreendido como uma estratégia do líder. Antes disso, os exércitos de Hideyoshi ainda não haviam conseguido entrar em Kyūshū ${ }^{68}$. Entretanto, depois de ter a ilha conquistada não haveria mais necessidade para dissimulação para com os estrangeiros. Para George Elison: "a expulsão dos padres não foi por si mesma uma medida xenofóbica. Era parte do programa de Hideyoshi de reestruturação da autoridade central do Japão". ${ }^{9}$

É importante notar, contudo, que, embora o líder não tenha tomado nenhuma medida concreta contra os missionários e cristãos, pela primeira vez o poder central interferia nas atividades dos estrangeiros, restringindo-as. ${ }^{70} \mathrm{O}$ comércio com Portugal, como foi colocado anteriormente, não foi proibido, como acontecerá posteriormente durante o governo Tokugawa.

Antes de deixar Kyūshū, contudo, Hideyoshi baixou algumas ordenanças anticristãs como a proibição do uso de bandeiras com cruz nos campos militares e navios; confisco de rosários e relíquias; confisco dos domínios de Mogi e Nagasaki (do poder da Companhia de Jesus) assim como a destruição de seus fortes juntamente com os de Arima e Ōmura (domínios pertencentes a daimyō cristãos). ${ }^{71}$

$\mathrm{Na}$ data do Edito o vice-provincial da missão, Gaspar Coelho, chegou a pedir à Hideyoshi para que fosse dado mais tempo para que os padres pudessem deixar o arquipélago (o Edito dava três meses), pois a nau do capitão Monteiro, que partiria em outubro do mesmo ano, não suportaria carregar tantos. A verdade, contudo, é que

\footnotetext{
${ }^{67}$ Aviso transcrito em ELISON, George, Deus Destroyed - The image of Christianity in early modern Japan, Harvard University Press, 1973, p. 118.

${ }^{68}$ Terceira maior ilha do Japão. Localizada mais ao sul do arquipélago. Local onde a atividade tanto dos jesuítas quanto dos mercadores portugueses foi mais intensa durante todo o "século cristão".

${ }^{69}$ ELISON, George, op. cit., p. 117. (tradução própria)

70 YAMASHIRO, José, op. cit., (1989).

${ }^{71}$ ELISON, George, op. cit.
} 
nenhum padre partiu definitivamente do Japão nessa nau, apenas três irmãos que foram, na realidade, ordenar-se em Macau. A estratégia de Coelho foi dispersar os cristãos. Ele chegou a planejar uma revolta com auxílio externo, mas quem chegou antes foi o padre Visitador Alexandre Valignano ${ }^{72}$, que consternado com a ideia do então falecido padre vice-provincial (Coelho morrera em maio de 1590), ordenou que se vendesse em segredo todo o armamento comprado e estocado por Coelho. ${ }^{73}$

Em 1592, por sua vez, os missionários jesuítas sofreram outro revés. Neste ano chegara a primeira embaixada enviada pelo governador de Manila, comandada por um dominicano e no ano seguinte, chegaram os primeiros franciscanos a pregar no Japão, vindos das Filipinas. A companhia de Jesus, única ordem cristã a pregar no Japão até então, passou a disputar terreno com os franciscanos e dominicanos (e a partir de 1602 com os agostinianos também) que acusavam os jesuítas de não seguirem a verdadeira doutrina cristã no Japão para melhor se fazerem aceitos.

A questão do monopólio da evangelização no arquipélago fora tema de discussão já desde o início da missão. Os jesuítas defendiam seu monopólio com o fim de evitar confundir os nativos com as dissensões existentes dentro da Igreja Católica ou da doutrina cristã. Alexandre Valignano, padre visitador das Índias Orientais durante o fím do século XVI, foi um ferrenho defensor de tal monopólio. ${ }^{74}$ A Companhia desfrutou de tal monopólio até a chegada dos dominicanos e franciscanos em 1592-93, muito embora somente em 1585 a Cúria Romana tenha declarado (através da bula ex pastorali officio do papa Gregório XIII) que o Japão deveria ser domínio exclusivo dos jesuítas. $^{75}$

A princípio Hideyoshi manteve também um bom relacionamento com os franciscanos, até porque estes vieram junto de uma embaixada espanhola das Filipinas. Além disso, o líder rapidamente notou o antagonismo existente entre as diferentes ordens e percebeu que poderia jogar com isso.

\footnotetext{
${ }^{72}$ Em sua segunda visita à missão ele chegou em 21 de julho de 1590 . Novamente fica no Japão por três anos.

${ }^{73}$ ELISON, George, op. cit., p. 134.

${ }^{74}$ Valignano dedica um capítulo do seu Sumario de las cosas de Japón (1583) para defender tal monopólio. Analisarei melhor sua posição no terceiro capítulo.

${ }^{75}$ ÜÇELER, M. Antoni J., The Jesuit Enterprise in Sixteenth-and Seventeenth-century Japan, in: WORCESTER, Thomas (ed.), The Cambridge Companion to the Jesuits, Cambridge University Press, 2008.
} 
O evento que mudou completamente o rumo da missão cristã no Japão ocorreu em outubro de 1596, quando o galeão espanhol San Felipe, que vinha das Filipinas em direção a Acapulco, encalhou na costa japonesa de Tosa. Hideyoshi ordenou o confisco da carga. Enquanto a tripulação do navio esperava a decisão final de Hideyoshi, o capitão espanhol, Francisco de Olandia, reclamou às autoridades japonesas dizendo que a Coroa espanhola não toleraria que seus navios fossem tomados ilegalmente. Irritado com a situação, Hideyoshi mandou prender 26 cristãos: seis frades franciscanos que chegaram em 1593, três japoneses jesuítas em treinamento e dezessete cristãos leigos. Todos foram levados à Nagasaki e crucificados em fevereiro de 1597, no primeiro martírio cristão da história do Japão.

A situação da missão só piorara desde o édito de expulsão de 1587. Contudo, com a morte de Hideyoshi no ano seguinte ao martírio e a disputa entre os clãs Toyotomi e Tokugawa pelo controle do país, os padres e irmãos ganharam certo fôlego e continuaram suas atividades. Ainda que tivessem que agir com maior discrição e prudência, conseguiram aumentar significativamente o número de cristãos.

A esperança da Companhia de Jesus de que a situação da missão no Japão mudaria para melhor ainda era grande. Em 1611, o Japão foi alçado à categoria de província e a China passou a ser sua vice-província. Valentim Carvalho foi o primeiro provincial do Japão. $^{76}$

Em 1612, contudo, a missão sofreu mais um revés. Arima Harunobu (um daimyō cristão $^{77}$ ) foi acusado de subornar a nova administração e em junho do mesmo ano acabou executado. Pouco depois, Ieyasu baixou seu primeiro édito anticristão nas áreas sob o controle direto do xogunato e em 1614 tal édito passou a valer para todo o país marcando o início de uma perseguição mais sistemática ao cristianismo por parte do poder central.

Oito meses depois de Ieyasu ter estendido a orientação anticristã para todo o território japonês, o governador de Nagasaki ordenou a expulsão de todos os cristãos da província. Neste ano, a Companhia contabilizava 115 jesuítas no Japão. Destes, 65 partiram para Macau e 23 para Manila, acompanhados ainda de 53 dōjoku $^{78}$. Antigos

\footnotetext{
${ }^{76}$ Ibdem.

${ }^{77}$ Dom Protásio era seu nome de batismo.

${ }^{78}$ Eram espécies de irmãos leigos dos jesuítas. O termo, apropriado pelos jesuítas, vem do japonês e referia-se aos noviços que moravam nos arredores dos templos budistas e serviam os monges.
} 
daimyō cristãos que se recusaram a apostatar (como Takayama Ukon e Naitō Takuan) exilaram-se nas Filipinas. Ao todo ficaram ainda 27 jesuítas escondidos no Japão.

Os que permaneceram continuaram fazendo conversões. Elisonas afirma que segundo os relatos desses padres e irmãos, entre 1614 e 1626 sete mil japoneses se converteram. $^{79}$

Contudo, após o decreto de 1614, não apenas os missionários eram proibidos de ficar no Japão, mas também qualquer japonês converso. Em setembro de 1622 e em dezembro de 1623, foram promovidas execuções públicas de cristãos em Nagasaki e Edo.

Neste último ano, Tokugawa Hidetada, então xogum, abdicou em favor de seu filho Iemitsu. Foi durante seu governo que a perseguição aos missionários que ainda restavam e aos cristãos nativos atingiu seu ápice.

Iemitsu trabalhou na erradicação do Cristianismo em duas frentes. A primeira, interna, que tornou a procura e a perseguição dos cristãos um instrumento de controle social. A segunda, externa, expressou a convicção de que o "perigo cristão" poderia ser eliminado caso o Japão ficasse isolado dos "meios de contágio". Daí a política que fícou conhecida como sakoku, ou seja, "isolamento nacional”. Através dessa política, o Japão restringiu ao máximo seu contato com o estrangeiro. Tal política durou até meados do século XIX, tendo acabado à força por pressão da então nova potência mundial: Estados Unidos.

O primeiro dos cinco decretos de seclusão nacional (sakoku-rei) foi baixado em 1633 e o último em 1639. Tais decretos restringiam as viagens de japoneses ao exterior (a partir de 1635 a punição para aquele que violasse essa regra era a morte), encorajavam a perseguição impiedosa do Cristianismo, proibiam a residência de qualquer europeu ou descendente no país e o último deles proibiu qualquer contato com os portugueses. ${ }^{80}$

Essa política de fechamento foi fatal para os missionários no Japão, pois acabou por isolá-los, cortando qualquer possibilidade de ajuda que poderiam receber de seus

\footnotetext{
${ }^{79}$ ELISONAS, Jurgis, Christianity and the Daimyō, in: HALL, John W. (ed.), op. cit., (1990).

${ }^{80}$ Os únicos europeus que mantiveram suas relações até a implementação dos decretos do sakoku foram os portugueses e holandeses.
} 
compatriotas comerciantes. Em 1633, o jesuíta Cristóvão Ferreira ${ }^{81}$ apostatou após ser pego pela polícia do xogunato e torturado por horas. Ele posteriormente se converteu ao zen budismo e mudou seu nome para Sawano Chūan. ${ }^{82}$

Em 1637, estourou a rebelião agrária de Shimabara. Tal revolta acirrou o processo de fechamento da nação e fez com que Iemitsu proibisse qualquer embarcação portuguesa de aportar em um porto japonês.

A revolta de Shimabara não foi exatamente uma revolta cristã, contudo, contou com alta participação de cristãos nativos. Os camponeses que a promoveram rebelavamse contra os altos impostos cobrados pelo senhor local, Matsukura Katsuie, que punia severamente aqueles que não conseguiam pagar. Tal política resultou em uma grave fome dentre a população camponesa que não viu outra opção senão a revolta. Os rebeldes tomaram o castelo de Hara e o senhor local teve que pedir ajuda ao poder central para debelar a revolta. Percebendo que tal situação poderia abrir um perigoso precedente, o xogunato enviou uma força de cem mil homens que conseguiram entrar no castelo somente no ano seguinte e mataram os 37 mil revoltosos que se encontravam ali dentro, sem se importar com a idade ou sexo dos mesmos.

A revolta de Shimabara é bastante significativa para o fim do século cristão japonês, pois mostrou ao xogunato Tokugawa que não apenas os missionários poderiam ser inconvenientes e até subversivos ao poder central, mas a própria doutrina cristã.

O fim do "século cristão" é datado por alguns historiadores, como George Elison $^{83}$, em 1639 com a interdição de qualquer contato com os portugueses. Os ingleses - que chegaram ao Japão em 1613 - assim como os espanhóis, já haviam desistido em 1623 do comércio no arquipélago ${ }^{84}$. A única nação européia que conseguiu manter relações comerciais com o governo Tokugawa foi a Holanda que jamais mostrou preocupação alguma em levar missionários que evangelizassem a população ${ }^{85}$. Contudo, mesmo eles sofreram restrições, tendo autorização apenas para frequentar o porto artificial de Deshima.

\footnotetext{
${ }^{81}$ Cristóvão Ferreira (1580-1650), português, chegou ao Japão em 1609.

82 ÜÇELER, M. Antoni J., The Jesuit Enterprise in Sixteenth-and Seventeenth-century Japan, in: WORCESTER, Thomas (ed.), op. cit.

${ }^{83}$ ELISON, George, Op. Cit.

${ }^{84}$ MATSUDA, Kiichi, The Relations Between Portugal and Japan, Lisboa: Junta de Investigações do Ultramar, 1965.

${ }^{85}$ Durante a revolta de Shimabara a Holanda emprestou sua artilharia para o xogunato na sua invasão ao castelo de Hara.
} 
Ralph Charles Boxer, o primeiro historiador que utilizou o termo "século cristão" para o Japão, data seu fim apenas em $1650^{86}$. Uma vez que o seu início é datado em 1549 - com a chegada de Francisco Xavier, Cosme de Torres e João Fernandez, os primeiros missionários a desembarcarem no arquipélago - somente em 1650 o cristianismo teria completado um século no Japão. Não se trata, portanto, de uma data que marque um acontecimento específico, mas que melhor responda a sua periodização.

A verdade, entretanto, é que o fim dos jesuítas ou qualquer outro missionário no Japão não marcou o fim do cristianismo ali. Em alguns locais, como na ilha Ikitsuki e nas ilhas Gotō, comunidades secretas de cristãos nativos se organizaram. Estes são chamados de kakure kirishitan (cristãos escondidos, em português). ${ }^{87}$

A perseguição aos mesmos não abrandou após a seclusão do país. Em 1646, foi criado em Edo o kirishitan yashiki, um centro de detenção, interrogação e tortura de cristãos que funcionou até o fim do século XVIII. ${ }^{88}$ A estratégia do Bakufu para encontrar cristãos incluía prêmios aos denunciantes, infiltração de agentes secretos e a obrigatoriedade de todos os moradores de aldeias filiarem-se ao templo budista local.

Portugal, por sua vez, não conseguiu reatar suas relações comerciais com o Japão por toda a era Edo. Em 1647, chegou ao Japão uma embaixada portuguesa com uma mensagem do novo rei de Portugal, D. João $\mathrm{IV}^{89}$. Tokugawa Iemitsu reiterou que banira completamente o comércio nanban ${ }^{90}$ pois os navios traziam missionários, mesmo após a interdição do Cristianismo ${ }^{91}$. As relações entre os dois países só foi restabelecida em 1860, nos últimos anos do Tokugawa Bakufu.

\footnotetext{
${ }^{86}$ BOXER, Ralph C., The Christian Century in Japan 1549-1650, Berkeley University of California Press, 1967.

${ }^{87}$ Sobre os kakure kishitan, ou cristãos escondidos, ver: DOUGILL, John. In Search of Japan's Hidden Christians - A Story of Supression, Secrecy and Survival, Tokyo, Rutland, Singapore: Tuttle Publishing, 2012. Tal pesquisa, recentemente publicada, foi feita nos últimos anos, num trabalho etnológico com alguns dos poucos descendentes dos kakure kirishitan que ainda restam no Japão contemporâneo.

${ }^{88}$ ÜÇELER, M. Antoni J., The Jesuit Enterprise in Sixteenth-and Seventeenth-century Japan, in: WORCESTER, Thomas (ed.), op. cit.

${ }^{89}$ Primeiro rei da dinastia de Bragança, subiu ao poder após a Restauração da Independência de Portugal e fim da União Ibérica em 1640.

${ }^{90}$ Nanban em português quer dizer "Bárbaros do Sul". Era forma como os portugueses eram chamados no Japão, uma vez que vinham sempre do sul (ilha de Kyushū).

${ }^{91}$ MATSUDA, Kiichi, op. cit.
} 
Para George Elison, "a aceitação do cristianismo foi um fenômeno peculiar da confusa política do Sengoku (...) e os fatores que tornaram isso possível foram anulados no governo Tokugawa de equilíbrio político e ortodoxia intelectual". ${ }^{92}$

Há registros de outros grandes martírios de cristãos nativos em datas posteriores como os 600 cristãos de Kori (distrito rural vizinho à Nagasaki) que foram presos em $1657-1658^{93}$, ou os dois mil cristãos de Owari e Mino, províncias do Japão central que durante o século cristão jamais figuraram como locais de forte presença cristã, segundo os relatos dos missionários. A maioria destes cristãos foi morta e alguns deles exilados. $^{94}$

É essencial frisar, portanto, que a total rejeição do cristianismo veio por parte das autoridades centrais que acreditavam que sua doutrina ia de encontro à nova sociedade que eles pretendiam construir. A presença dos kakure kirishitan, por sua vez, demonstra não apenas uma aceitação da nova religião como uma apropriação da mesma por parte da população. Como Üçeler afirma:

Ao fim, sem qualquer clérigo para auxiliá-los, os 'cristãos escondidos' ou kakure kirishitan acabaram por misturar a cultura folclórica, junto com elementos de rituais xintoístas e budistas, nas suas expressões religiosas cristãs. Por mais 'imperfeitas' que estas formas altamente ecléticas de cristianismo possam ser, elas testemunharam a tenacidade com a qual esses japoneses se agarraram na fé e tradições de seus ancestrais o tanto que conseguiram se lembrar, entender e transmiti-las em segredo, de geração em geração. ${ }^{95}$

Cercados pelo aparato que o governo central procurou montar, os kakure kirishitan são expressão de uma parte da população japonesa que, mesmo arriscando-se contra o Bakufu, buscou formar uma identidade, não nacional, mas própria.

\footnotetext{
${ }^{92}$ ELISON, George, op. cit., p. 2 (tradução minha).

${ }^{93}$ Destes 411 foram executados, 77 morreram na prisão e 99 foram soltos após apostatar.

${ }^{94}$ BOXER Ralph C., op. cit. (1967).

95 ÜÇELER, M. Antoni J., The Jesuit Enterprise in Sixteenth-and Seventeenth-century Japan, in: WORCESTER, Thomas (ed.), op. cit., p. 164 (tradução minha).
} 


\section{Cap. 2. A missão cristã durante o superiorato de Cosme de Torres (1551-1570)}

\section{OS PORTUGUESES NA ÁSIA E A CHEGADA DOS JESUÍTAS NO JAPÃO}

As notícias acerca do Japão já circulavam na Europa, ainda que de forma fragmentária, desde o relato de Marco Polo que, apesar de jamais ter pisado em solo japonês, conta em sua obra de uma terra mais ao leste da Mongólia e China, denominada "Cipango" (romanização da pronúncia chinesa jih-pên kuo que significa terra do sol nascente ${ }^{96}$ ). Seus relatos, na opinião do historiador Charles Boxer, teriam marcado uma nova era no conhecimento europeu sobre o oriente longínquo ${ }^{97}$.

A expedição de Vasco da Gama no fim do século XV levou os portugueses à Índia, através do Cabo da Boa Esperança, e em 1510 eles já possuíam uma fortaleza em Goa. No ano seguinte conquistaram Malaca, graças a uma rede de alianças que fizeram com a comunidade mercantil da cidade ${ }^{98}$. Tal conquista possibilitou a abertura do Pacífico aos europeus, principalmente portugueses.

Não se sabe ao certo se os portugueses que comercializavam em Malaca com a China e regiões adjacentes chegaram antes a alguma parte do Japão, mas o primeiro relato de um europeu que tenha pisado no em solo nipônico é de 1542 , como já foi relatado anteriormente. Em poucos anos, os comerciantes portugueses passaram a incluir o Japão na sua rota comercial. Os navios partiam de Malaca, Patane e Ayuthaia, escalavam em algum ancoradouro chinês, onde embarcavam mercadorias (principalmente a seda), e partiam para o Japão de onde traziam basicamente prata. ${ }^{99}$

Em 1542, menos de dois anos depois da bula papal Regimini Militantis Ecclesia que institucionalizava a recém-formada ordem católica Companhia de Jesus, Francisco Xavier, o único integrante do grupo fundador a sair da Europa, chegava à Índia com os primeiros missionários jesuítas na Ásia.

Em 1547, ele encontrou-se com Anjiro ${ }^{100}$, um pirata japonês que abrigara-se no navio português do capitão Jorge Alvarez por ser procurado em seu país graças a uma rixa na qual acabou por assassinar um homem. Anjiro confessou-se com Xavier e

\footnotetext{
${ }^{96} \mathrm{LACH}$, Donald. Japan in the eyes of Europe - The sixteenth century, Chicago: University of Chicago Press, 1968.

${ }^{97}$ BOXER Ralph C., op. cit. (1967).

${ }^{98}$ SUBRAHMANYAM, Sanjay, op. cit.

${ }^{99}$ LOUREIRO, Rui Manuel, op. Cit .(2007)

${ }^{100}$ Encontra-se também a grafia Yajiro.
} 
converteu-se, segundo o relato do próprio Xavier e de Luis Fróis na sua História de Japam $^{101}$.

Xavier já sabia da existência desse reino mais ao leste, com o qual os portugueses comercializavam há alguns anos e pedira ao capitão português Alvarez para que escrevesse um relatório sobre a terra e seu povo. Ele o elaborou em 1547. Neste, Alvarez descrevia os portos, casas, fortalezas, clima - o qual dizia ser uma terra com muitos tufões, terremotos e furacões - e ainda alguns costumes dos japoneses. Afirmava que estes eram orgulhosos, facilmente se ofendiam, mas eram também gentis, liberais e curiosos para com os estrangeiros, diferente da maioria dos asiáticos do continente. Ele ainda fez uma breve descrição das religiões locais: o budismo e o culto aos kamis ${ }^{102}$, fazendo inclusive uma diferenciação entre ambas. Descreveu os chamados bonzos ${ }^{103} \mathrm{e}$ afirmou que os japoneses se mostravam bastante curiosos acerca dos ensinamentos cristãos. Alvarez, no entanto, lembrou que o único porto que esteve foi o de Yamagawa (sudeste de Satsuma) e que jamais adentrara mais que nove milhas no território japonês ${ }^{104}$.

Com o relatório de Alvarez nas mãos e junto de Anjiro - a partir de então Paulo de Santa Fé - que aprendera a falar o português, Xavier animou-se em muito com a possibilidade de evangelizar o povo japonês. Já em 1547 iniciou a montagem da missão e chamou para acompanhá-lo, Paulo de Santa Fé, seu criado Joane, Antonino - outro japonês converso - e dois criados: um malabar - Amador - e outro chinês - Manoel. Além deles, Xavier pediu ao padre Cosme de Torres e ao irmão João Fernandez para acompanhá-los ${ }^{105}$.

Ao que parece a vontade de Xavier de ir ao Japão era tão grande que quando chegou à Malaca, como não encontrou nenhum navio português, arriscou-se a ir em um

\footnotetext{
${ }^{101}$ FRÓIS, Luis, História de Japam, volume I, Lisboa: Biblioteca Nacional de Lisboa, 1976 (1597).

102 O "culto aos kami” é vulgarmente chamado de Xintoísmo. Este é comumente definido como a religião nativa do Japão. Contudo, para esse período trata-se de um conceito de pouca aplicabilidade, como já foi explicado no primeiro capítulo, uma vez que somente na Era Meiji (1868-1912) que a ideia de uma religião xintoísta - não budista - ganhou larga aceitação. Para mais detalhes ver: SCHEID, Berhard e TEEUWEN, Mark. Tracing Shinto in the History of Kami Worship. Japanese Journal of Religious Studies, 29/3-4, p. 195-207, 2002. Ou também: RAVERI, Massimo. Índia e Extremo Oriente: via da libertação e da imortalidade. Tradução Camila Kintzel. São Paulo: Hedra, 2005.

${ }^{103}$ Modo de referir-se aos sacerdotes budistas. A definição de bonzo no "Vocabulario da Lingoa de Iapam com adeclaração em Portugues, feito por alguns padres e irmãos da Companhia de Iesu" de 1603 é: "religioso comum e sem dignidade".

${ }^{104}$ LACH, Donald, op. cit. e BOXER Ralph C., op. cit.

${ }^{105}$ FRÓIS, Luis, História de Japam, volume I, Lisboa: Biblioteca Nacional de Lisboa, 1976 (1597).
} 
navio "china pirata gentil" 106 . Chegaram ao porto da cidade de Kagoshima, principal da província de Satsuma, localizada na ilha de Kyūshū, em 15 de agosto de 1549. Fizeram lá poucas conversões em parte pelo desconhecimento da língua nativa. João Fernandez desde Malaca iniciara seu aprendizado do japonês, mas ainda falava e entendia muito pouco.

Luis Fróis e Cosme de Torres relatam esse primeiro encontro afirmando que os japoneses se mostravam bastante curiosos acerca da nova doutrina. Relataram também suas primeiras discussões e conversas com alguns sacerdotes budistas.

Dois anos depois, em 1551, Xavier resolveu voltar à Índia para de lá ajudar na evangelização da nova vinha. Assim que chegou ao continente, mandou ao Japão o padre Baltazar Gago e os irmãos Duarte da Silva e Pedro de Alcáçova. No Japão ficaram apenas o irmão João Fernandez e o padre Cosme de Torres, que passou a ser o encarregado da nova missão.

\section{A VIDA EXEMPLAR DE COSME DE TORRES}

Cosme de Torres (1510-1570) foi o primeiro superior da missão do Japão e o que mais tempo permaneceu nessa função ${ }^{107}$. A particularidade de sua vida se encontra nos registros de suas cartas escritas na Ásia e enviadas aos seus irmãos na Europa. Como nenhum jesuíta dentre os pesquisados no presente trabalho, ele fez nas suas cartas uma longa retrospectiva de sua vida ${ }^{108}$. Escreveu em algumas delas que antes da sua entrada na Companhia de Jesus vagou pelo mundo a procura de algo "que não sabia" (segundo suas próprias palavras) "tendo sempre resistido", até que por fim encontrou a tão procurada "quietude de espírito" e contentamento quando fez os Exercícios Espirituais de Loyola e entrou para a Companhia de Jesus. A partir de então, sua vida passou a ser regrada e disciplinada e ele enfim sentiu-se satisfeito.

\footnotetext{
${ }^{106}$ Segundo as palavras de Fróis em FRÓIS, Luis, História de Japam, volume I, Lisboa: Biblioteca Nacional de Lisboa, 1976 (1597), cap. 1.

${ }^{107} \mathrm{O}$ mandato dos superiores na China e Japão tem uma média de tempo maior do que as outras províncias jesuíticas do período (Portugal, Brasil, Goa e Malabar). Ver: COSTA, João Paulo A. Oliveira. O Cristianismo no Japão e o episcopado de D. Luis Cerqueira. Tese (doutorado em História dos descobrimentos e da expansão portuguesa) - Faculdade de Ciências Sociais e Humanas da Universidade Nova de Lisboa. Lisboa, 1998.

${ }^{108}$ Tal relato foi feito em pelo menos duas cartas: uma a Ignácio de Loyola, Simon Rodrigues e demais jesuítas da Europa, escrita em Goa, em janeiro de 1549 e a outra aos jesuítas de Valência, de Yamaguchi, no Japão, em 29 de setembro de 1551. Ambas as cartas estão presentes em: MEDINA, Juan Ruiz de (ed.), Documentos del Japon 1547-1557, Roma: Instituto Histórico de La Compañia de Jesus, 1990.
} 
Cosme de Torres nasceu em 1510, em Valência, na Espanha, e aos vinte e seis anos de idade foi ordenado sacerdote tendo passado a ensinar gramática em Mallorca. No entanto, ele conta que nesse momento de sua vida, seu coração "nunca quietava", mesmo após voltar a Valência para estudar teologia e cânones.

Encontrou na sua cidade natal um frade franciscano chamado Juan de Torres que o chamou para ir junto dele à Nova Espanha. Cosme aceitou o convite "no sabiendo lo que me llamava, olvidado de padre e madre e ermanos e parientes e tanbién de la patria" 109 . Na Nova Espanha passou a ensinar gramática aos frades e "moços da terra", mas continuava sentindo uma repugnância dentro de si.

Depois de quatro meses foi chamado pelo governador para fazer missa em sua casa, onde ficou por mais quatro anos "com muitos prazeres", mas sempre querendo outra coisa que não sabia o que, até que, contra a vontade de todos com quem convivia, decidiu embarcar numa armada para as Molucas.

Chegou nelas em 1546, onde conheceu Xavier, que ali pregava. Logo se encantou com o jesuíta, mas ficou pouco tempo com ele, pois partiu no mesmo ano para Goa, onde o bispo the deu uma vicaria na qual ficou por quatro meses "sem quietude no coração". Na época só havia dois padres jesuítas em Goa - Nicolau Lancillotto, reitor do colégio, e Paulo de Carneiro - e Torres os inquiriu por diversas vezes acerca das suas vidas na Companhia. Decidiu fazer os Exercícios Espirituais em 1548, instruído por Lancillotto. Com eles sentiu grande contentamento e paz, mas ao acabá-los teve grandes tentações até que se reencontrou com Xavier que o convidou para ir junto dele ao Japão. Ele não apenas aceitou o convite como decidiu, naquele momento, entrar para a Companhia.

No Japão, depois que Xavier deixou o arquipélago em 1551, Torres ficou responsável pela missão. A descrição que os padres e irmãos da Companhia fazem dele é de um homem extremamente pio e devoto. Fróis na sua História chegou a fazer uma descrição bastante exaltadora dele. Segundo seu relato, Torres sempre comia pouco, jamais se achegava ao fogo "mesmo no frio do Japão", estava sempre descalço - a não ser que fosse visitar um senhor - e rezava a missa todos os dias, ainda que velho e

\footnotetext{
${ }^{109}$ Cosme de Torres. Carta aos jesuítas de Goa. 29 de setembro de 1551. In: MEDINA, Juan Ruiz de (ed.), Documentos del Japon 1547-1557, Roma: Instituto Histórico de La Compañia de Jesus, 1990, p. 222.
} 
enfermo. Era sempre o primeiro a levantar-se e o último a deitar, ajudava os pobres e enfermos e, quando recebia esmolas, as repartia entre todos os cristãos. Além disso, "estava ornado de uma estranha paciência em sofrer injúrias, opróbios e desprezos"110. Os cristãos, por sua vez, tinham grande amor e estima por ele e chegavam a guardar restos de cabelo dele, mesmo sabendo ser proibido.

Quando Torres morreu, em 1570, Fróis relatou que:

Em tanta estima e acatamento era tido de todos que, acabando de o enterrar, não ficou paninho, nem camisa, nem contas, nem outra cousa similhante que não levassem e repartissem em grande número de partes, tendo cada cousa daquellas por relíquia, sem lho poderem deffender, por mais que os padres e irmãos lho proibiam. ${ }^{111}$

As duas cartas citadas acima que Torres enviou do Japão relatando sua vida foram impressas e extensamente divulgadas e lidas na Europa. Além disso, o fato de uma pessoa, descrita como tão pia e devota, fazer a descrição de sua vida afirmando ter tido no passado tanta inquietação e desgosto de si mesmo e só ter encontrado paz na Companhia de Jesus servia, claramente, como propaganda da mesma.

Tais cartas também serviam como propaganda da missão japonesa. Uma vez que o cenário das missões era definido pelas personagens que nelas se localizavam (tanto missionários, quanto infiéis ou pagãos), assim como pelas relações geradas a partir deste encontro, o fato de um padre tão admirável quanto Torres trabalhar nela e ainda ser tão amado pelos cristãos conversos engrandece consideravelmente tal missão.

\section{OS JAPONESES E A NOVA APOSTA DA COMPANHIA}

Como já foi relatado, o primeiro contato dos jesuítas com um japonês foi ainda em Malaca com o pirata posteriormente converso, Paulo de Santa Fé. Apesar de seu passado, Xavier e Torres aparentemente ficaram bastante impressionados com a inteligência do moço que teria "tão claro juízo e entrou tanto no conhecimento de Deus", além de ser "de tanta memória e engenho". ${ }^{112}$

\footnotetext{
${ }^{110}$ FRÓIS, Luis, História de Japam, volume I, Lisboa: Biblioteca Nacional de Lisboa, 1976 (1592), p. 125.

${ }^{111}$ FRÓIS, Luis, História de Japam, volume II, Lisboa: Biblioteca Nacional de Lisboa, 1981 (1592), p. 330.

${ }^{112}$ Cosme de Torres. Carta. 25 de janeiro de 1549. In: MEDINA, Juan Ruiz de (ed.), Documentos del Japon 1547-1557, Roma: Instituto Histórico de La Compañia de Jesus, 1990, p. 100.
} 
Assim que chegaram ao Japão, apesar de terem enfrentado grandes dificuldades devido ao desconhecimento da língua e cultura nativa, Xavier, Torres e o irmão João Fernandez ficaram muito animados com a possibilidade de expansão na nova vinha.

As primeiras notícias acerca da nova missão foram dadas por Xavier que escreveu uma carta seis semanas após sua chegada em Kagoshima. Tal carta foi enviada à Goa e rapidamente copiada e enviada para a Europa onde passou a circular já em 1552. Nesta carta Xavier afirmava que o povo japonês era o melhor já descoberto. Ele elogiava sua sociabilidade, boas maneiras, senso de honra e falta de malícia. Além disso, afirmou que embora fossem pagãos, estavam dispostos a ouvir argumentos contra suas crenças e "vícios". 113

O juízo que Cosme de Torres fez dos japoneses não foi diferente. Na primeira carta que escreveu do Japão, dois anos após sua chegada, ele afirmava que:

Estes japões são mais aparelhados pera que em elles se plante nossa santa fée que todas as gentes do mundo. São discretos quanto se pode cuidar. Governão-sse pola razão tanto ou mais que os espanhoes. São curiosos de saber mais que quantas gentes eu tenho conhecido, e de praticar de que maneira salvarão suas almas e servirão a quem os criou. Em todo o descoberto não há homens de sua maneira. ${ }^{114}$

Os elogios de Torres não pararam por aí. Na mesma carta ele ainda afirmara que os mesmos falavam tão bem que "parece que todos eles se criarão em paços de grandes senhores", não possuíam inveja uns dos outros nem julgavam. Ao fim, ainda coloca que "se ouvera de escrever todalas boas partes que há em elles, antes faltaria tinta e papel que matéria". 115

Assim, mesmo sendo o futuro da missão ainda incerto (lembremos que as conversões nos primeiros anos não foram numerosas), tanto Xavier como Torres mostraram-se impressionados e animados com a população japonesa.

\section{Os melhores cristãos}

A despeito de todas as dificuldades que encontraram, os poucos missionários que trabalhavam no Japão mantiveram uma alta estima do povo nativo. Não apenas os

\footnotetext{
${ }^{113}$ LACH, Donald, op. cit.

${ }^{114}$ Cosme de Torres. Carta. 29 de setembro de 1551. In: MEDINA, Juan Ruiz de (ed.), Documentos del Japon 1547-1557, Roma: Instituto Histórico de La Compañia de Jesus, 1990, p. 212.

${ }^{115}$ Cosme de Torres. Carta. 29 de setembro de 1551. In: ibid., p. 213.
} 
japoneses eram considerados tão "civilizados" quanto os europeus, como também ótimos cristãos ${ }^{116}$.

Segundo as notícias que temos pelas cartas de Cosme de Torres e dos relatos de Luis Fróis - que apesar de só ter chegado ao Japão em 1564 trabalhou em Malaca, entre 1554 e 1557, como copiador das cartas que circulavam na Ásia, além de ter juntado diversas delas posteriormente para poder escrever a sua História de Japam - os japoneses conversos eram bastante disciplinados na fé. Torres escreveu, numa carta de 1560, que os cristãos nativos frequentavam todos os domingos as missas, além das festas do Evangelho ${ }^{117}$. Além disso, os japoneses eram sempre descritos como constantes na fé e mesmo quando perseguidos por serem cristãos eles eram, segundo os relatos, capazes de colocar sua vida em risco para não irem contra a lei de Deus ${ }^{118}$. Eram também muito inclinados à devoção e penitência além de seguirem sempre a razão ${ }^{119}$ (que se bem usada confirmaria os ensinamentos cristãos, segundo os missionários).

A insistência em tais descrições demonstra a comoção por parte dos jesuítas que as escreveram, mas também servia a alguns fins. Primeiramente, à promoção da nova missão. Os jesuítas que trabalharam no Japão sempre tiveram que exercer suas atividades com número bastante reduzido de padres e irmãos, mas isso é verdade ainda mais para essa fase inicial do primeiro superiorato de Cosme de Torres. O historiador Daril Alden afirma que Torres jamais teve mais do que treze companheiros jesuítas no Japão, sendo que apenas sete deles eram padres ${ }^{120}$. A promessa de uma nova missão próspera deveria, portanto, animar aqueles que estavam na Europa a enviarem mais missionários, além de fundos para o Japão - essencial para a manutenção da missão que não possuía ainda renda própria.

\footnotetext{
${ }^{116}$ Tal estima pelo povo japonês permaneceu por muito tempo, segundo os relatos dos jesuítas, como veremos ao analisar o superiorato seguinte de Francisco Cabral.

${ }^{117}$ Cosme de Torres. Carta a Melchior Nunes Barreto. 20 de outubro de 1560. In: MEDINA, Juan Ruiz de (ed.), Documentos del Japón 1558-1562, Roma, Institutum Historicum Societatis Iesu, 1995.

${ }^{118}$ Cosme de Torres. Carta ao Geral da Companhia. 24 de outubro de 1566. In: GARCIA, José Manuel (ed.). Cartas que os Padres da Companhia de Iesus Escreverão dos Reynos de Iapão e China aos da mesma Companhia da Índia e Europa des do anno de 1549 até o de 1580, vol. I, Maia, Cotovia, 1997. Luis Fróis também conta na sua História de Japam casos em que cristãos japoneses preferem morrer a deixar sua fé.

${ }^{119}$ Cosme de Torres. Carta a Antônio de Quadros. 08 de outubro de 1561. In: MEDINA, Juan Ruiz de (ed.), op. cit., (1995).

${ }_{120}$ ALDEN, Daril. The Making of an Enterprise - The Society of Jesus in Portugal, its empire and beyond 1540-1750, Standford: Standford University Press, 1996.
} 
Além disso, com as grandes navegações o mundo tornava-se cada vez maior e a Companhia precisava eleger determinados locais para mandar seus missionários. Um importante critério para esta escolha era justamente a disponibilidade do gentio (onde a porta estivesse mais aberta), assim como uma maior devoção e desejo da sua parte ${ }^{121}$ critérios absolutamente preenchidos a julgar pelas animadas cartas analisadas até aqui.

O pequeno contingente de missionários, por outro lado, os impediria de espalharem-se pelo território japonês. Pelas cartas, contudo, os jesuítas não hesitaram em deixar algumas áreas, com um número até significativo de cristãos, sem nenhum padre ou irmão para que pudessem chegar a outras cidades e províncias e aumentar o número de batismos e conversões. A prudência jesuítica, contudo, só permitiria tal conduta caso eles tivessem certeza de que os cristãos que fossem deixados para trás permaneceriam firmes em sua fé, da forma que lhes foi ensinada. Tal estratégia será posteriormente criticada por Francisco Cabral, o segundo superior da missão, que defendia que cada casa jesuíta no Japão deveria ter ao menos três ou quatro missionários, mesmo que isso implicasse no fechamento de algumas delas. ${ }^{122}$ Cabral, contudo, não foi o único a defender tal estratégia. O próprio padre Geral, Francisco Borja, enviara uma carta em 1567 ao provincial do Peru, na América espanhola, ordenando que os jesuítas fossem a poucas partes e atendessem primeiramente os já cristianizados, cuidando para conservá-los, e depois convertessem outros, seguindo o critério inaciano de ganhar pouco a pouco, fortificando o que já ganhou. ${ }^{123}$ Parece, contudo, que as cartas dos primeiros jesuítas do Japão conseguiram cumprir seu papel, uma vez que tal orientação não foi dada a Cosme de Torres por nenhum de seus superiores.

Além disso, a persistência de comunidades cristãs relativamente numerosas em domínios de daimyō hostis ao cristianismo (como veremos, em alguns casos daimyō não cristãos chegavam a permitir a atividade dos missionários em seus domínios, mas depois de um tempo os expulsavam e proibiam a evangelização em seus territórios) como Hirado, Yamaguchi, Higo, Satsuma, demonstra que os missionários conseguiram

\footnotetext{
${ }^{121}$ LONDOÑO, Fernando Torres. Escrevendo Cartas. Jesuítas, Escrita e Missão no Século XVI. Revista Brasileira de História, São Paulo, V. 22, nº 43, p. 11-32, 2002.

${ }^{122}$ Francisco Cabral. Carta ao Padre Diego Miró do Colégio de Roma. 06 de setembro de 1571. In: CORREIA, Pedro Lages Reis. Francisco Cabral and Lourenço Mexia in Macao (1582-84): two different perspectives of evangelization in Japan. Bulletin of Portuguese/Japanese Studies, Universidade Nova de Lisboa, vol. 15, dez-2007 (p. 47-77).

${ }^{123}$ LONDONO, Fernando Torres, op. cit., p. 28.
} 
formar algumas comunidades que se consolidaram, ainda que longe da presença dos padres e irmãos ${ }^{124}$. Se essas comunidades praticavam os rituais e cerimônias cristãs da forma que os missionários esperavam é difícil de dizer, arriscaria dizer que é muito provável que não, contudo, creio que para esse caso apenas o fato de elas se autodenominarem cristãs já é suficiente para que sejam consideradas comunidades consolidadas de cristãos japoneses.

\section{A RELAÇÃO COM AS CRENCAS LOCAIS}

(...) Não podemos chegar à Religião - e assim ao mundo - senão por meio de um ponto de vista, o que vemos será inevitavelmente uma consequência do nosso enfoque particular. As diferenças que temos quanto à religião são o resultado dessas diferenças radicais de contexto e perspectiva. ${ }^{125}$

A asserção de Willian Paden transcrita acima é aplicável tanto aos missionários do século XVI aqui estudados quanto a nós leitores contemporâneos. Da mesma forma, cabe a ambos sua afirmação de que a "religião não é um tópico independente, simplesmente exposto à observação de todos, mas um termo que seu usuário escolhe para associar certos tipos de fenômenos" ${ }^{126}$. Assim, pode-se dizer que tanto nós, pesquisadores do século XXI, quanto os missionários do XVI, escolhemos determinados fenômenos sociais para definirmos como religião.

Para espalhar o Evangelho em terras de pagãos, os missionários procuraram entender melhor aquilo que denominaram como "religiões locais". Apesar de crerem que o cristianismo era a única religião verdadeira, contavam com a existência de outras, ainda que as considerassem falsas. O termo religião, proveniente do latim (religio), refere-se primordialmente a uma observância sagrada ${ }^{127}$, portanto a construção de uma ligação com o sagrado. Assim, aquilo que denominaram como "religiões praticadas no Japão" deveria, mal ou bem, encaixar-se nessa definição. Não que isso não existisse quer no Japão, quer em qualquer outro lugar do mundo. Seguindo o esquema interpretativo da religião comparada, pode-se considerar a religião como uma forma universal de cultura, contudo, continua valendo a afirmação de Paden de que a religião não é um objeto ao qual temos acesso independentemente de nossas descrições, mas é

\footnotetext{
${ }^{124}$ COSTA, João Paulo Oliveira e. Op. Cit., 1998, pag. 587.

125 PADEN, Willian E. Interpretando o Sagrado - modos de conceber religião, tradução Ricardo Gouveia, São Paulo: Paulinas, 2001, pag. 9.

${ }^{126}$ Idem, pag. 20. (grifo meu)

${ }^{127}$ Idem, pag. 21.
} 
um objeto já formado por nossas definições. Ainda que aceitemos sua existência em diferentes sociedades, ao interpretá-la ela necessariamente passa por um processo de conceitualização, que é dependente do seu intérprete.

Xavier, antes de chegar ao Japão, munira-se de alguns relatos sobre a população e clima japoneses feitos por Anjiro e Jorge Alvarez. Estes incluíam uma breve descrição das chamadas "religiões" praticadas no arquipélago. Estas seriam o Budismo, vindo da Índia através da China e Coréia - o historiador Donald Lach afirma que de início Xavier provavelmente não entendera que o budismo praticado no Japão era a mesma religião que encontraram na China e Índia com algumas variações locais ${ }^{128}$ - e a "religião dos kamis", como posteriormente os jesuítas passaram a chamar todas as práticas e crenças de adoração aos kami. ${ }^{129}$

Como é de se esperar, as informações que Xavier recebeu eram confusas a tal ponto que ele mesmo chegou a pregar, encorajado pelas informações dadas ainda em Malaca por Anjiro, que Dainichi - uma força maior do Budismo da seita Shingon - era sinônimo do Deus cristão. É importante destacar, por outro lado, que Anjiro era um homem simples e não fazia parte da elite intelectual japonesa. Seu conhecimento acerca do budismo era de um nível popular, por assim dizer. Ele não tinha, portanto, noção de uma filosofia e ensinamentos mais profundos. Desta forma, ele foi incapaz de transmitir a Xavier que no entendimento budista não há um deus criador de tudo. Embora as diversas seitas possam divergir acerca da criação do mundo, como poderemos atestar mais à frente, nenhuma elege um deus criador do universo ${ }^{130}$.

Não podemos, contudo, imputar somente a Paulo de Santa Fé (ou Anjiro) a responsabilidade pela não compreensão dos conceitos budistas por Xavier e seus companheiros. No primeiro encontro com o desconhecido, a reação tanto dos jesuítas quanto dos mercadores que frequentaram os portos japoneses, foi uma tentativa de racionalizar o objeto desconhecido (no caso o Japão) através de uma aproximação com o conhecido ${ }^{131}$ ou, como coloca Cristina Pompa: “a comparação analógica era o único

\footnotetext{
${ }^{128}$ LACH, Donald, op. cit.

${ }^{129}$ SCHEID, Berhard e TEEUWEN, Mark.Op. cit.

130 SINDEMANN, Kerstin-Katja. Japanese Buddhism in the $16^{\text {th }}$ century. Letters of the Jesuit missionaries. In: Bulletin of Portuguese/Japanese Studies, Universidade Nova de Lisboa, vol. 2, p. 111133, jun-2001.

${ }^{131}$ RADULET, Carmen M. O 'Cerimonial' do Padre Alessandro Valignano: encontro de culturas e missionação no Japão. O Século Cristão do Japão: actas do colóquio internacional comemorativo dos 450 anos de amizade Portugal-Japão (1543-1993). Lisboa, Nov-1993.
} 
instrumento epistemológico de compreensão cultural". ${ }^{132}$ Se somente somos capazes de enxergar aquilo para que temos uma categoria, com a religião não poderia ser diferente.

Posteriormente, em conversas com os monges de Satsuma, Xavier percebeu seu erro conceitual e notou que as seitas praticadas no Japão eram derivadas da religião praticada na Índia e China. Xavier passou a afirmar então que Dainichi era uma manifestação do demônio e não poderia ser adorado. Aqui, mais uma vez, o jesuíta faz uma analogia com o conhecido, uma vez que na filosofia budista não há um "diabo".

Mais do que um 'erro' - como foi colocado anteriormente - tal situação deve ser entendida como um mal-entendido proveniente da tradução entre culturas. Tais malentendidos ocorreram certamente nos dois lados das partes em causa, uma vez que a tradução era praticada por todos os sujeitos envolvidos no processo do encontro. Aqui temos contato com apenas um dos lados: os jesuítas europeus. Como promotores de tantos encontros entre culturas, entretanto, é importante notar que, como coloca Adone Agnolin:

Em termos de comunicação intercultural e em razão da convivência com a diversidade cultural e das intenções de evangelização (fundada no pressuposto universalista da missão), os missionários são necessariamente vítimas e produtores privilegiados de malentendidos. ${ }^{133}$

Creio poder afirmar, contudo, que a preocupação que os jesuítas tiveram, a partir de então, em entender e desqualificar tanto as religiões nativas quanto seus sacerdotes é bastante peculiar do caso japonês. Xavier, Torres e Fernandez assim que chegaram perceberam a alta estima que os japoneses tinham pelos religiosos. Xavier afirmou em uma de suas missivas, contudo, que os "bonzos" eram os piores inimigos dos missionários ${ }^{134}$. Talvez em termos de disputa política Xavier estivesse correto, mas com certeza a simples existência dos tais bonzos facilitou bastante o caminho dos jesuítas em diversos aspectos. $\mathrm{O}$ fato de os religiosos serem uma classe respeitada no Japão é um bom exemplo da ajuda indireta que os mesmos deram aos jesuítas. Na China, onde os religiosos eram mal vistos, os jesuítas tiveram grande dificuldade em compreender tal

\footnotetext{
${ }^{132}$ POMPA, Cristina. Religião como tradução: missionários, Tupi e "Tapuia” no Brasil colonial. Bauru: EDUSC, 2003

133 AGNOLIN, Adone, Jesuítas e Selvagens - A negociação da fé no encontro catequético-ritual americano-tupi (séculos XVI-XVII). São Paulo: Humanitas editorial, 2007, p. 194.

${ }^{134}$ LACH, Donald, op. cit.
} 
situação e tiveram de fazer sérias concessões para se 'acomodar' à cultura local ${ }^{135}$. A proposta do futuro Visitador das Índias Orientais, Alexandre Valignano, de imitar os bonzos - particularmente os da seita zen - para que os jesuítas melhor se fizessem aceitos, é exemplar para entender essa espécie de "simbiose mal-querida".

É verdade, entretanto, que os jesuítas que escreviam do Japão mostravam grande preocupação em desqualificar os chamados "bonzos". Luis Fróis e Cosme de Torres os descreviam como homens "carnais", despreocupados com a salvação tanto de si quanto da população, dissimulados e, apesar de serem "homens de letras" - os jesuítas perceberam que se tratava da elite intelectual japonesa -, jamais conseguiam vencer as disputas (discussões) com os padres e irmãos. No tratado que Fróis escreve sobre os costumes do Japão ${ }^{136}$, ele dedica um capítulo inteiro a falar dos bonzos ${ }^{137}$ sempre os descrevendo como péssimas pessoas, ao contrário da maioria dos japoneses.

Os missionários, contudo, se dedicaram também ao estudo das religiões praticadas no Japão. Em 1556, já estava compilado um tratado, denominado Sumário dos erros em que os gentios do Japão vivem e de algumas seitas gentílicas em que principalmente confia, acerca destas ${ }^{138}$. O tratado não está assinado, mas diversos historiadores como George Schurhammer, Jorge Alvarez-Taladriz, Jurgis Elisonas e Juan Ruiz de Medina não hesitam em atribuir a Cosme de Torres, então superior da missão, ao menos a autoria principal.

O tratado buscou sistematizar um pouco das crenças religiosas presentes no Japão. Ele dá um panorama bastante confuso, uma vez que havia uma grande diversidade de seitas budistas no Japão, além das crenças nos kami. É importante atentar para o fato, contudo, que a despeito de todo o esforço que os jesuítas tiveram para entender as crenças locais, eles não tinham acesso aos ensinamentos mais profundos e complexos do budismo, os quais somente o alto clero budista possuía. Para Kerstin

\footnotetext{
${ }^{135}$ PINA, Isabel. The Jesuit Missions in Japan and in China: two distinct realities. Cultural adaptation and the assimilation of natives. Bulletin of Portuguese/Japanese Studies, Universidade Nova de Lisboa, vol. 2, p. 59-73, jun-2001.

${ }^{136}$ FRÓIS, Luis. Europa Japão: um diálogo civilizacional no século XVI: tratado em que se contêm muito sucinta e abreviadamente algumas contradições e diferenças de costumes entre a gente de Europa e esta província de Japão (...), Lisboa: Comissão Nacional para as Comemorações dos Descobrimentos Portugueses, 1993 [1597].

${ }^{137}$ Capítulo IV: "No que toca aos bonzos e seus costumes".

${ }^{138}$ Sumário dos erros em que os gentios do Japão vivem e de algumas seitas gentílicas em que principalmente confiã, In: MEDINA, Juan Ruiz de (ed.), Documentos del Japon 1547-1557, Roma: Instituto Histórico de La Compañia de Jesus, 1990.
} 
Sindemann, os missionários não conseguiram nem ao menos distinguir os ensinamentos budistas dos mitos populares, tão disseminados dentre a população da época. ${ }^{139}$

O sumário não dá nome às seitas budistas e em diversos pontos elas se contradizem essencialmente, como acerca do princípio do mundo ou da existência ou não de outras vidas. A verdade, entretanto, é que diferentemente do cristianismo - ainda que o mesmo estivesse sofrendo naquele momento tensões sectárias - o budismo não poderia ser apresentado pelos missionários como uma visão unificada, justamente pela grande contradição existente entre as nove escolas budistas existentes no Japão do século XVI. ${ }^{140}$

O tratado afirma que a maioria das seitas budistas negava a existência de uma alma e, segundo os ensinamentos daqueles tidos como fundadores do Budismo - Shaka e Amida -, "não há nada além de nascer e morrer". Tal ensinamento, contudo, provém do zen-budismo, que afirmava que "o Nada tornou-se Ser e o Ser tornar-se-á Nada"141. A complexidade do termo Nada, o qual é entendido paradoxalmente como uma entidade que se refere a tudo, não foi analisada pelos missionários, como podemos perceber pelo Sumário em questão.

Shaka e Amida, por sua vez, não seriam deuses, segundo o Sumario, mas homens que existiram no passado ${ }^{142}$. O sumário, no entanto, refere-se também a diversos deuses que são adorados: os "camins" (refere-se aos kami) que incluiriam o sol e a lua. Estes foram percebidos como entidades que não faziam parte da doutrina budista, mas daquilo que o Sumário denomina como "seita dos camins". 143

A preocupação dos jesuítas em entender melhor a doutrina das religiões praticadas, assim como em fazer sistematizações das mesmas e enviá-las aos seus colegas tanto de Goa quanto da Europa, demonstra a preocupação que tinham em poder discutir e rebater os argumentos colocados tanto pelos sacerdotes quanto por leigos. Isso é particularmente verdade para o caso japonês uma vez que a única forma que os

\footnotetext{
${ }^{139}$ SINDEMANN, Kerstin-Katja, op. cit.

140 Ibdem.

${ }^{141}$ Ibdem, p. 124 (tradução minha).

${ }^{142} \mathrm{O}$ tratado afirma que tanto Amida como Shaka eram homens que viveram no passado. Contudo, Shaka é o único que tem uma real existência (trata-se de Gautama, o Buda). Amida não passa de uma abstração, bastante invocada pelo budismo da seita Jodō (Terra Pura), a mais popular do Japão nesse período.

${ }^{143}$ ELISONAS, Jurgis S. A. The Jesuits, the Devil and Pollution in Japan. The context of syllabus of errors. Bulletin of Portuguese/Japanese Studies, Lisboa: Universidade Nova de Lisboa, Vol./ano 1, p. 327, dez-2000.
} 
missionários tinham para conseguir catequizar a população local era através do convencimento, uma vez que não contavam com a ajuda de qualquer poder coercitivo. A afirmação da superioridade de seu próprio saber era, portanto, essencial no processo de evangelização dos japoneses. ${ }^{144}$

Além disso, os jesuítas desde o início enfatizaram a racionalidade presente nos japoneses. Cosme de Torres afirmara que não apenas eles governavam-se pela razão, mas também que, se através dela fossem convencidos da necessidade de converterem-se para salvarem suas almas, na mesma hora eles esqueceriam seus ídolos e far-se-iam cristãos $^{145}$. Desta forma, uma boa preparação intelectual era essencial para os obreiros do Japão. Cosme de Torres explicita isso numa carta escrita em setembro de 1551, ao afirmar que os japoneses só deixariam de converter-se caso fossem enviados ao Japão homens de "poucas letras". 146

\section{A EVOLUÇ̃̃ DA MISSÃO E O PAPEL DO SUPERIOR UNIVERSAL DO JAPÃO}

Francisco Xavier, Cosme de Torres e João Fernandez, como vimos anteriormente, desembarcaram no Japão pelo porto de Kagoshima na província de Satsuma. Lá ficaram por um ano até que decidiram partir para Hirado, segundo Torres porque "não fazíamos muito fruito". ${ }^{147}$ A chegada de um navio de mercadores portugueses no porto vizinho de Hirado, entretanto, em muito influenciou essa viagem assim como a antipatia do daimyō local - Shimazu Takahisa - que decepcionara-se com a ausência de outros navios portugueses em seus domínios.

Torres permaneceu em Hirado enquanto Fernandez e Xavier partiram para Yamaguchi onde montaram uma residência que acabou por ser encerrada em 1556, devido às guerras locais. A residência de Hirado, por sua vez, resistiu por mais dois anos, mas também se encerrou em 1558, após o daimyō local - Matsūra Takanobu - os expulsarem. A missão de Hirado permaneceu oficialmente fechada nos seis anos seguintes, muito embora os missionários ainda a visitassem periodicamente. Em 1561, Torres enviou uma carta a Antonio Quadros afirmando que a missão no Japão encontrava-se dividida em oito "lugares ou províncias" sendo uma delas a de Hirado,

\footnotetext{
${ }^{144}$ PROSPERI, Adriano, O Missionário, In: VILLARI, Rosário (org.). O homem barroco. Lisboa: Editorial Estampa, 1995.

${ }^{145}$ Cosme de Torres. Carta aos jesuítas de Goa. 29 de setembro de 1551. In: MEDINA, Juan Ruiz de (ed.), Documentos del Japon 1547-1557, Roma: Instituto Histórico de La Compañia de Jesus, 1990.

${ }^{146}$ Cosme de Torres. Carta. 29 de setembro de 1551. In: ibid.

${ }^{147}$ Cosme de Torres. Carta. 29 de setembro de 1551. In: ibid., p. 208.
} 
onde se encontravam dois mil cristãos. ${ }^{148}$ Em 1564, Takanobu recebeu o padre Luis Fróis junto do irmão João Fernandez e permitiu a reabertura oficial da missão, assim como a construção de uma nova igreja. ${ }^{149} \mathrm{O}$ daimyō jamais se converteu ao cristianismo mas permitiu, a partir de então, a presença dos missionários, assim como suas atividades, dentro de seus domínios até o ano de sua morte, em 1599. Contudo, seu filho e sucessor - Matsūra Shigenobu - não simpatizava com os jesuítas e no mesmo ano da morte de seu pai expulsou os Ichibu e os Koteda - descendentes de um ramo colateral da casa Matsuda que possuíam diversos membros conversos - e, sem protetores, a missão de Hirado acabou por encerrar-se definitivamente.

A carta de Cosme de Torres citada acima ainda enumera outros sete locais onde "manifestava-se a lei de Deus": Bungo, Cutami (espécie de condado do senhor de Bungo, segundo o próprio Cosme de Torres), Fakata ${ }^{150}$, Kagoshima (local onde se iniciou a pregação, mas após a saída dos missionários, em 1550, ninguém retornou, muito embora Torres afirme na carta que os cristãos de lá escreviam periodicamente para ele), Yamaguchi (Torres chega a dizer que os missionários não podiam voltar para lá, mas que os cristãos escreviam periodicamente a ele pedindo para que retornasse pois eles permaneciam firmes na fé), Meaco ${ }^{151}$ e Sacai $^{152}$.

Sabemos que na época da primeira visita do padre Alexandre Valignano (157982) a missão estava dividida em três partes, cada uma delas dirigida por um superior que era subordinado ao Superior Universal do Japão. As partes eram: Shimo, Bungo e Miyako. A missão de Shimo só foi oficializada após a morte de Torres em 1572, tendo o padre Gaspar Coelho como seu primeiro superior. Shimo, no entanto, nada mais era do que a junção dos reinos de Arima, Amakusa, Omura e Hirado. As missões de Bungo e Miyako são citadas na carta de Torres, como pudemos ver. Ambas tiveram sua

\footnotetext{
${ }^{148}$ Cosme de Torres. Carta a Antônio de Quadros. 08 de outubro de 1561. In: MEDINA, Juan Ruiz de (ed.), Documentos del Japón 1558-1562, Roma, Institutum Historicum Societatis Iesu, 1995.

${ }^{149}$ RIBEIRO, Madalena Teotónio Pereira Bourbon, A Nobreza Cristã de Kyūshū. Redes de parentesco e ação jesuítica, dissertação (mestrado em História) - Faculdade de Ciências Sociais e Humanas da Universidade Nova de Lisboa. Lisboa. 2006.

${ }^{150}$ Hakata.

151 Myako.

152 Sakai.
} 
abertura oficializada em 1560, sendo o primeiro superior de Miyako o padre Gaspar Vilela ${ }^{153}$ e o de Bungo o padre Baltazar Gago. ${ }^{154}$

Para o caso de Bungo, antes dessa data os jesuítas já haviam montado, em 1553, uma pequena missão em Funai ${ }^{155}$ - cidade castelo do daimyō de Bungo, Otomo Sorin (converteu-se no superiorato seguinte e foi batizado como dom Francisco) - que posteriormente passou a pertencer à missão de Bungo.

Funai foi o centro das atividades de caridade dos jesuítas no Japão durante a primeira década da missão. Já em 1554, fora montado um pequeno dispensário e em 1555, graças ao dinheiro doado por Luís de Almeida ${ }^{156}$, foi construído um orfanato e dois anos depois um hospital que posteriormente foi aumentado para incluir uma ala exclusiva para leprosos.

Tais obras de caridade foram características da primeira fase da missão japonesa que, a partir do segundo superiorato (de Francisco Cabral), passou a privilegiar o bom relacionamento com as elites japonesas, como poderemos ver detalhadamente no capítulo seguinte, e acabou por negligenciar, embora jamais abandonar, tais obras. ${ }^{157}$

Cosme de Torres faleceu sem jamais ter ido à Miyako. Isso porque, durante seu superiorato, o Superior Universal do Japão possuía uma função diferente da que passou a ter após o superiorato de Francisco Cabral. Muito mais do que uma concepção diferente de tal cargo, Torres acabou por reagir segundo as possibilidades conjunturais. Em seu superiorato, o número de missionários era extremamente reduzido, como pudemos ver, e o Superior não poderia desempenhar um papel, como fez Cabral e seus sucessores, de supervisor da missão. Torres foi muito mais um obreiro como qualquer outro que esteve junto dele e, do que podemos depreender de seus relatos, jamais desempenhou um papel de vigilância.

\footnotetext{
153 Torres conta na sua carta de outubro de 1561 que mandou Vilela para Miyako após receber uma carta de um bonzo que pedia para que ele enviasse alguém à capital para que ele pudesse ouvir a "lei de Deus", porém quando o padre chegou lá o bonzo já havia falecido.

${ }^{154}$ Regulamentos dos P.P. da Companhia para boa administração e fructo das Missões no Japão, principiados a escrever em 1585. Compreende tamben a descripção, costumes, Religião e qualidades do Japão, e algumas notícias desde 1549 até 1597; e tamben uma memória da mercancia, que os P.P. da Companhia sempre fizerão no Japão para sustentar as Missões naquelas partes. In: TALADRIZ, J. C. Alvarez, Monumenta Nipponica Monographs, Tóquio: Sophia University, v. 9, 1954, p. 68-69 nota 6.

${ }^{155}$ Atual Ōita.

${ }^{156}$ Luís de Almeida era um mercador português, de ascendência judia, que doou sua fortuna às obras de caridade da missão no Japão e entrou na Companhia em 1556. Ele era também físico e cirurgião.

${ }^{157}$ ELISONAS, Jurgis S. A., op. cit., (2000).
} 
Já Cabral demonstrou uma postura bastante diferenciada e, em carta de 1571, escreveu que o Superior Universal não deveria ter casa fixa, mas deveria estar sempre visitando as residências jesuítas espalhadas pelo território japonês. ${ }^{158}$ Tal itinerância seria altamente necessária, em sua opinião, para que o Superior pudesse vigiar o trabalho dos outros padres e irmãos, sendo esta a sua verdadeira função.

\section{A IMPORTÂNCIA DO MODO DE AGIR}

A missão japonesa possui uma peculiaridade que direcionou em grande parte a ação dos missionários que é o fato destes, diferente do que aconteceu em outras regiões asiáticas, não ficarem à sombra de feitorias e fortes do Estado português da Índia, mas viverem integrados à sociedade japonesa, sem poderem contar muito com seus conterrâneos. Assim, tiveram que se adaptar, muito mais que em outras situações, ao modo de vida local.

Como afirma o historiador português Rui Manuel Loureiro, não se pode falar de uma política de adaptação para os primeiros anos da missão ${ }^{159}$. Contudo, a partir das missivas do primeiro superior da missão, Cosme de Torres, podemos perceber a importância que ele dá ao modo de agir dos missionários dentro da missão japonesa.

Já na sua carta de 1551 aos jesuítas de Goa ele pedia: “considerem pois, os que se houverem de preparar para vir a estas partes, que princípios se têm postos em esta terra" ${ }^{\prime 160}$. Mais adiante ele ainda prossegue: "hão de ser os padres mui prudentes pera se saber acomodar com a gente da terra, a qual cousa hé mui dificultosa"161 . Tal conhecimento e disposição seriam tão necessários, segundo ele explica numa carta de mesma data dirigida aos jesuítas de Valência, que:

(...) por dos solas causas, hablando umanamente, los japones se pueden dexar de fazer cristianos: o por no venir padres o, viniendo, ser ombres de pocas letras e poco espirimentados, especialmente en la virtud de paciência. ${ }^{162}$

\footnotetext{
${ }^{158}$ Francisco Cabral. Carta ao Padre Diego Miró do Colégio de Roma. 06 de setembro de 1571. In: CORREIA, Pedro Lages Reis, op. cit. (2007).

${ }^{159}$ LOUREIRO, Rui Manuel, Jesuit Textual Strategies in Japan between 1549 and 1582, in: Bulletin of Portuguese/Japanese Studies, Lisboa: Universidade Nova de Lisboa, Vol. 8, Junho, 2004.

${ }^{160}$ Cosme de Torres. Carta aos jesuítas de Goa. 29 de setembro de 1551. In: MEDINA, Juan Ruiz de (ed.), Documentos del Japon 1547-1557, Roma, Institutum Historicum Societatis Iesu, 1995,p. 210.

${ }^{161}$ Cosme de Torres. Carta aos jesuítas de Goa. 29 de setembro de 1551. In: Ibid., p. 217.

${ }^{162}$ Cosme de Torres. Carta aos jesuítas de Valência. 29 de setembro de 1551. In: Ibid., p. 229.
} 
Além disso, ele prossegue, os padres "alén de ser sabios, prudentes e omilldes, an de ser exercitados en meditar, porque los mas destes padres e seglares casi consumen toda su vida em este exercicio". ${ }^{163}$

Assim, percebemos que para o primeiro superior da missão, os jesuítas deveriam portar-se de maneira que se fizessem compreendidos e respeitados pelos nativos segundo os parâmetros destes, daí a importância da meditação e do conhecimento dos costumes japoneses. Como vimos, ele preocupou-se em descrever os costumes, religião e organização política do Japão em suas cartas assim como no tratado das crenças japonesas, já comentado anteriormente. Em uma carta que ele escreveu em 1561 a Antônio Quadros e outra do mesmo ano a Diego Laínez, ele descreveu o clima, a terra, as principais autoridades (religiosas e temporais) e a personalidade do povo japonês. Tais descrições não serviam apenas à curiosidade do exótico, presente naquele século de tantas descobertas, mas também à necessidade de informar os jesuítas, afim de melhor aparelhá-los para a nova missão.

Não por isso Torres estava completamente seguro da forma como deveriam proceder no Japão. Seu superiorato ocorreu ainda numa fase inicial da Companhia de Jesus que só teve suas Constituições aprovadas e impressas em $1559^{164}$. Não sabemos ao certo a data em que elas chegaram às mãos dos missionários que se encontravam no Japão, mas nas cartas só são citadas em anos bem posteriores, principalmente por Francisco Cabral, enquanto defendia seu método de evangelização para o Japão em contraposição ao método de Alexandre Valignano.

As Fórmulas do Instituto da Companhia, por sua vez, já haviam sido aprovadas em 1540 pelo Pontífice Paulo III ${ }^{165}$ e davam uma orientação bastante genérica para todos os jesuítas, independente do local em que trabalhavam. Contudo, regras mais exatas, principalmente para o contexto das missões longínquas, se faziam necessárias. Torres explicitou isso na sua carta de 1557 a Loyola e Quadros, quando "suplica" para que "nos mande algunas reglas de que manera nos avemos de ever entre esta jemtilidad

\footnotetext{
${ }^{163}$ Cosme de Torres. Carta aos jesuítas de Valência. 29 de setembro de 1551. In: Ibid., p. 229.

${ }^{164}$ O’MALLEY, John W. Os primeiros jesuítas. Bauru: EDUSC; São Leopoldo: UNISINOS, 2004.

${ }^{165}$ LOYOLA, Ignácio de (santo), Constituições da Companhia de Jesus e normas complementares, São Paulo: Loyola, 1997.
} 
fuera de nuestra ley e costumbres" ${ }^{166}$. Provavelmente ele referia-se a ordens que pudessem guiá-lo melhor na condução da missão. Tais regras, no entanto, só foram sistematizadas ao fim do segundo superiorato, após a visita de Alexandre Valignano. Torres descreveu nesta carta como estava ordenando o dia dos irmãos, padres e estudantes e enfatizou que guardava grande parte do dia dos irmãos para o estudo da língua japonesa.

Outra evidência de que Torres não estava seguro quanto ao melhor modo de proceder na missão é o documento intitulado Resposta que alguns padres de Japão mandaram perguntar ${ }^{167}$. O tratado foi escrito no ano de 1570 , pelo jesuíta português Francisco Rodrigues (1515-1573), reitor do colégio de São Paulo em Goa. Trata-se de respostas que ele deu a quarenta e sete questões enviadas à Índia, entre os anos de 1563 e 1568 , pelos missionários do Japão ${ }^{168}$.

Francisco Rodrigues fez parte do movimento "em favor do cristianismo" da Índia, nos anos de 1540, que restringiram drasticamente a participação política e a liberdade de cultos dos muçulmanos e hindus em Goa. A despeito do seu histórico, Rodrigues se mostrou bastante flexível nas respostas que deu às indagações dos jesuítas da missão japonesa.

As perguntas formuladas dizem respeito basicamente às atitudes que os padres deveriam ter perante os neófitos ou àqueles que queriam converter-se: quais proibições ou concessões deveriam fazer. Na maioria das respostas, por sua vez, Rodrigues teve uma atitude bastante compassível para com os japoneses. A maneira como ele termina o documento é ilustrativo da sua atitude demonstrada nas respostas:

(...) aviso para bem da Christandade o qual he muitas vezes convir pretender dos novamente convertidos tanta perfeição que lhe seia causa ou de retrocederem, ou ao menos de não goardarem aquillo que boamente podem porque segundo se colige das perguntas que de la vem parece não se desemilão algas coisas a eses christãos pelas quais se podia boamente pasar.

\footnotetext{
${ }^{166}$ Cosme de Torres. Carta a Ignácio de Loyola e Antonio Quadros. 07 de novembro de 1557. In: MEDINA, Juan Ruiz de (ed.), Documentos del Japon 1547-1557, Roma, Institutum Historicum Societatis Iesu, 1995, p.739.

${ }^{167}$ Francisco Rodrigues. Resposta que alguns padres de Japão mandaram perguntar. 1570. In: PINTO, Ana Fernandes e PIRES, Silvana Remédio. The 'Resposta que alguns padres de Japão mandaram perguntar': a clash of strategies. Bulletin of Portuguese/Japanese Studies, Lisboa: Universidade Nova de Lisboa, Vol. 10-11, Junho-Dezembro, 2005, p. 9-60.

${ }^{168}$ Ibidem.
} 
(...) donde achandosse defeitos en alguns christãos que se possão tolerar fazendo se boamente com elles pera que se apartem se senão apartarem devem se lhe dissimular e sendo taes os defeitos que se não posão tolerar basta tratar os que os cometem conforme a seus merecimentos sem mais estrondo nem perturbação dos outros. ${ }^{169}$

Rodrigues justificou muitas das respostas que deu pela necessidade de "evitar escândalos", esperança de mais conversões, ignorância por parte dos nativos de estarem em uma situação pecaminosa, escassez de missionários e necessidade de conformidade social. Ele demonstrou uma grande sensibilidade para com o caso japonês, ainda que jamais tenha visitado o arquipélago.

Assim como o padre Visitador Alexandre Valignano o fez posteriormente, Rodrigues defendeu que determinadas práticas dos japoneses, ainda que acontecessem durante cerimônias e ritos religiosos, eram ritos civis e, portanto, não poderiam ser proibidas pelos missionários. Da mesma forma, os missionários não deveriam impor nada que dissesse respeito aos ritos civis de seus países de origem.

No caso dos casamentos disparatas cultis (por disparidade de cultos), ${ }^{170}$ ele afirmou que deveriam ser autorizados, pois tal impedimento seria somente de direito positivo, ainda que alguns dissessem que era de direito natural ou divino. Para o caso dos cristãos cujos parentes morriam gentios e precisavam, portanto, acompanhar seus enterros e suas cerimônias, ou daqueles que iam aos banquetes de gentios da comunidade em dias que a igreja proibia comer carne, Rodrigues apelou para o mesmo expediente: a proibição do consumo de carne era de direito positivo e não poderia ser imposto. Já os funerais eram também ritos civis da comunidade (mesmo que fossem também religiosos) e, ainda que o cristão ficasse obrigado a declarar publicamente que se convertera ao cristianismo, ele deveria ser permitido de acompanhar os ritos funerários.

Apesar de tantas dúvidas acerca do modo de proceder correto (talvez justamente devido a essas incertezas), durante o primeiro superiorato não se acendeu qualquer discussão acerca do modo de proceder dos missionários no Japão. Sabemos, no entanto, que Cosme de Torres não assumiu um papel de supervisor da missão e os jesuítas que lá

\footnotetext{
${ }^{169}$ Francisco Rodrigues. Resposta que alguns padres de Japão mandaram perguntar. 1570. In: PINTO, Ana Fernandes e PIRES, Silvana Remédio. Op. cit. p. 57-58.

${ }^{170}$ Pergunta 2: se poderá o christão de Japão cazar sua christãa com algum infiel de sua qualidade porque não a cazando com homem de tal calidade tem se por grande desonra cazar se com inferior.
} 
trabalharam até a chegada de Francisco Cabral, em 1570, tiveram uma grande liberdade de atuação. Na carta que Cabral escreveu no ano seguinte de sua chegada ao arquipélago, ele afirmou que embora alguns jesuítas estivessem usando roupas de seda em seus vestuários, Cosme de Torres alegara ser contra tal costume que fora se introduzindo contra a sua vontade ${ }^{171}$, muito embora o superior não tenha reclamado disto em nenhuma das suas cartas das quais temos acesso.

\section{A IMPORTÂNCIA DAS MISSIVAS DENTRO DA COMPANHIA DE JESUS}

A Companhia de Jesus foi uma ordem fundada com fins pastorais. Tal orientação já estava presente nas Fórmulas do Instituto da Companhia, que dizia que a Companhia fora instituída para "o aperfeiçoamento das almas na doutrina cristã e para a propagação da fé" e que todos seus membros deveriam estar dispostos a ir a qualquer canto do mundo exercer a atividade apostólica caso fossem mandados ${ }^{172}$, e foi reforçada logo em seguida pelas Constituições. A atividade apostólica deveria, portanto, ser levada para os mais longínquos lugares da Terra. Assim, a necessidade de uma comunicação periódica que informasse principalmente o núcleo central da Ordem representado pelo padre Geral que ficava em Roma - era essencial para que a Companhia não perdesse sua coesão.

A importância que as cartas assumiram na organização da ordem, portanto, é primordial. Uma vez que elas constituíam a única forma de comunicação direta da época entre pessoas distantes, somente através delas os missionários poderiam receber ordens de seus superiores e informá-los do andamento das missões - algo essencial em se tratando de uma ordem extremamente hierarquizada como a Companhia. A comunicação através das cartas obedecia, porém, não somente uma lógica vertical, mas também horizontal, que seria para a união dos ânimos de todos os membros da Companhia. ${ }^{173}$ A escrita assume, assim, a forma predominante de comunicação, ação e registro.

\footnotetext{
${ }^{171}$ Francisco Cabral. Carta ao Padre Diego Miró do Colégio de Roma. 06 de setembro de 1571. In: CORREIA, Pedro Lages Reis. op. cit. (2007).

${ }^{172}$ Fórmulas do Instituto da Companhia de Jesus (aprovadas e confirmadas pelo sumo pontífice Paulo III em carta apostólica Regimini Militantis Ecclesia em 27 de setembro de 1540). In: LOYOLA, Ignácio, op. cit., p. 29-30.

${ }^{173}$ LONDOÑO, Fernando Torres, op. cit.
} 
A obrigatoriedade do envio periódico das mesmas, expressa nas Constituições, assim como uma preparação intelectual elaborada fez com que os jesuítas se tornassem observadores privilegiados das realidades com as quais conviviam nas missões.

Para José Eisenberg:

(...) durante essa fase de consolidação da Companhia de Jesus, muitas das normas que regulavam as atividades dos jesuítas foram produzidas localmente e justificadas por aqueles que as produziam por meio do envio periódico de cartas ${ }^{174}$.

Desta forma, através das cartas, as autoridades locais da missão, como Francisco Xavier e Cosme de Torres no Japão, acabaram por regular certas práticas, ainda que inconscientemente, que transcenderam a sua pessoa, como poderemos ver quando analisarmos o superiorato seguinte de Francisco Cabral. A comunicação se coloca, portanto, como uma forma privilegiada de ação.

Além disso, as cartas dos missionários do Japão provocaram desde cedo uma considerável atividade editorial na Europa. Já em 1565, a primeira edição dedicada exclusivamente ao Japão era lançada na Europa, mais especificamente em Coimbra. A "Copia de las cartas que los padres y hermanos de la Compañia de Iesus que andan en el Iapon escrevieron a los de la misma Compañia de la India y Europa desde el año de MDLVII que começaron hasta el passado de LXII. En Coimbra. Por Juan de Barrera y Juan Alvarez. MDLXV' foi a primeira de uma série de coletâneas de cartas de jesuítas que trabalharam na missão do Japão. ${ }^{175}$

Até a edição da famosa coletânea de Évora das cartas edificantes da Companhia (que foi reeditada em 1997 por José Manuel Garcia e da qual fazemos uso no presente trabalho) diversas edições apareceram em outros países da Europa como Lovaina (156970), Espanha (1575), Itália (1578), França (1579), dentre outros ${ }^{176}$. A edição de livros relativos a uma única missão revela, por sua vez, a importância que lhe era atribuída tanto pelos editores quanto pelo público leitor. Tais cartas e obras que as acompanhavam respondiam às expectativas com relação às missões de fora da Europa e

\footnotetext{
${ }^{174}$ EISENBERG, José, As Missões Jesuíticas e o Pensamento Político Moderno: encontros culturais, aventuras teóricas, Belo Horizonte: Editora UFMG, 2000, p. 46.

${ }^{175}$ COSTA, João Paulo A. Oliveira. Op. Cit., 1998.

${ }^{176}$ Ibidem.
} 
ajudaram a produzir todo um imaginário missionário assim como um método de atuação entre os gentios. ${ }^{177}$

Para a posterioridade, tais cartas servem como testemunhos do processo de encontro entre os missionários e os nativos das terras de missões. Embora sejam relatos pessoais, formam, como afirma Paulo Montero, "uma narrativa na qual se depositam inúmeras vozes, em contraponto ou em uníssono". ${ }^{178}$

Os missionários, por sua vez, tinham total noção de que escreviam para serem lidos por muitos outros e que produziam um texto para ser interpretado, repassado e lembrado ${ }^{179}$. As cartas dirigidas aos superiores, no entanto, possuíam um caráter diferenciado. Não tinham o compromisso de edificar a missão e podiam conter as discórdias e problemas enfrentados pelos missionários atuantes.

Para um momento em que, nas palavras de Montero, "a religião se constituiu no instrumento preferencial para dizer e pensar a cultura dos outros" ${ }^{\prime 180}$, as cartas, tratados e outras obras desses missionários, ainda que sejam discursos parciais, são fontes essenciais para entendermos o processo do encontro.

${ }^{177}$ LONDOÑO, Fernando Torres, op. cit., p. 22.

${ }^{178}$ MONTERO, Paula, Deus na Aldeia: missionários, índios e mediação cultural, São Paulo: Globo, 2006, p. 13.

${ }^{179}$ LONDOÑO, Fernando Torres, op. cit., p. 18.

${ }^{180}$ MONTERO, Paula, op. cit., p. 20. 
Cap. 3. A missão cristã durante o superiorato de Francisco Cabral (1570-1581)

\section{COSME DE TORRES E A ESCOLHA DE FRANCISCO CABRAL}

A procura por um sucessor para Cosme de Torres iniciou anos antes de sua morte em 1570, pois sua idade e doença começavam a impedi-lo de desempenhar seu cargo. Já em 1559, Francisco Cabral escrevia uma carta a Diego Laínes ${ }^{181}$ com uma relação dos padres e irmãos que estavam no Japão. Nesta, ele afirmava que Cosme de Torres possuía "má disposição do estômago" ${ }^{182}$. Luis Fróis também citou a saúde debilitada do padre em carta de 1563 - ano em que chegou ao Japão e encontrou Cosme de Torres - contando que o superior estava velho e com um pé machucado ${ }^{183}$.

Por fim, o próprio Cosme de Torres pediu para ser substituído por ser já muito velho e estar sem grande disposição de saúde para tamanho trabalho. Em carta de 1566 ao Geral da Companhia em Roma, ele afirmou já ter pedido ao provincial da Índia para que mandasse um padre para reger e governar os padres, irmãos e a cristandade do Japão. $^{184}$

Neste ano de 1566, Pero Ramirez, reitor do colégio de São Paulo em Goa, designou Antonio Quadros como novo superior da missão do Japão. Contudo, o navio que o levava afundou a caminho do arquipélago. ${ }^{185}$ Francisco Cabral acabou por ser a segunda escolha.

Cabral era português, nascido em 1533, na província portuguesa de Covilhã. Foi para a Índia em 1550, não como um jesuíta, mas como soldado, a pedido do vice-rei de Goa, Dom Alfonso de Noronha ${ }^{186}$. Lá sua vocação o chamou para outros combates e em 1554 ele entrou para a Companhia. Muito cedo passou a assumir cargos de grande responsabilidade como: reitor do colégio de Baçaim, posteriormente de Cochim e por fim de Goa. Em 1567, o padre provincial propôs a profissão do quarto voto, o que ocorreu somente em 1569 em Macau (antes que ele partisse ao Japão). Era criticado por

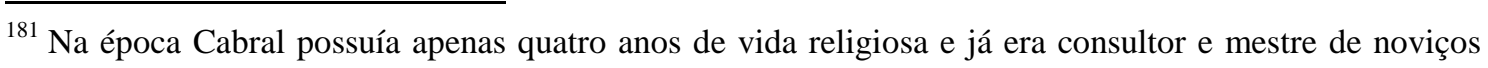
em Goa.

${ }^{182}$ Francisco Cabral. Carta a Diego Laínes. 25 de novembro de 1559. In: MEDINA, Juan Ruiz de (ed.), Documentos del Japón 1558-1562, Roma, Institutum Historicum Societatis Iesu, 1995.

${ }^{183}$ Luis Fróis. Carta para os irmãos de Europa. 14 de novembro de 1563. In: GARCIA, José Manuel (ed.), op. cit.

${ }^{184}$ Cosme de Torres. Carta ao Geral da Companhia. 24 de outubro de 1566. In: Ibid.

${ }^{185}$ BOURDON, Leon. La Compagnie de Jésus et le Japon, Lisboa-Paris: Comission Nationale pour les commemorations des decouvertes portugaises, , 1993.

${ }^{186}$ Seu governo foi de $1550-1554$.
} 
alguns por ser muito intransigente e autoritário, a antíteses de Cosme de Torres descrito como doce, tímido e escrupuloso. ${ }^{187}$

\section{O PROGRESSO DA MISSÃO - A CRISTIANIZAÇÃO DA ELITE}

Assim que os primeiros missionários chegaram ao Japão não conseguiram fazer conversões, senão dentre a população pobre e carente do arquipélago, muitas vezes atraídas pelas obras de caridade dos mesmos. Numa carta de 1554 a Baltazar Gago e João Fernandez - que alternavam seu trabalho entre Yamaguchi e Funai - Cosme de Torres afirmara que:

Os pobres continoamente vêm ouvir a pregaçam e se fazem delles cristãos. Aprendem as oraçois. Cada dia vêm a rezar, e depois lhe dam huma caixa e se vam muito consolados, dando graças a nosso Senhor que lhes tem feita tamta mercê, que hé pera se louvar a Deos nosso Senhor. ${ }^{188}$

Fróis contou ainda, numa carta de 1556, que os japoneses possuíam pouco conhecimento de medicina e os pobres padeciam sem ter ninguém que soubesse curálos, por isso tinham grande necessidade dos padres, principalmente daqueles que soubessem física ${ }^{189}$.

As conversões entre a população pobre e carente e ainda os trabalhos de caridade tanto entre os doentes (hospitais) como entre os pobres necessitados (orfanato, distribuições de comida, etc.) ajudou os jesuítas na conversão de um grande número de pessoas, mas os afastou em muito da elite japonesa, acostumada a carregar privilégios, inclusive no tocante às práticas religiosas. A elite inicialmente via o cristianismo como uma religião dirigida aos pobres e doentes.

Francisco Cabral afirmou, numa carta de 1576, que a cristandade em Funai aumentara muito graças à conversão do segundo filho do daimyō Otomo Yoshishige, Chikaie (batizado Sebastião). Nela ele conta que:

(...) no princípio, quando se começou a fazer a Christandade em Funay, foi por gente baixa e doente de doenças contagiosas, porque tínhamos um hospital aonde se curavão todos os enfermos que vinhão, polo que se faziam Chistãos e assi ficou sempre em

\footnotetext{
${ }^{187}$ BOURDON, Leon, op. cit.

${ }^{188}$ Cosme de Torres. Carta aos jesuítas de Bungo. 20 de agosto de 1554. In: MEDINA, Juan Ruiz de (ed.), Documentos del Japon 1547-1557, Roma, Institutum Historicum Societatis Iesu, 1990, p. 457-458.

${ }^{189}$ Luis Fróis. Carta aos jesuítas de Goa. 07 de janeiro de 1556. In: MEDINA, Juan Ruiz de (ed.), Documentos del Japón 1558-1562, Roma, Institutum Historicum Societatis Iesu, 1995.
} 
Funay tão mal acreditada a lei de Deos, visto como não havia homem honrado (...) que a quisesse tomar por se não misturar com tal gente como esta, e posto que com esta obra de misericórdia, de que os padres usavam, se edificassem muito, e juntamente com sua vida, todavia para o acrescentamento da Chistandade era muito estorvo, e assi vinte annos que aqui residimos em Funay hum só homem fidalgo se fez Chistão, e este depois de o curarmos em casa. ${ }^{190}$

O primeiro fidalgo que sabemos ter se convertido foi ainda cedo, em 1553. Não era uma figura de grande importância na política, mas descendente de um ramo colateral da casa Matsūda (clã daimyō de Hirado). Foi o padre Baltazar Gago quem batizou Koteda Yatsune (Antônio) e seu irmão (João). O batismo de ambos encontra-se pouco documentado devido ao fato de a correspondência deste ano ter-se perdido quase que inteiramente. Pedro de Alcáçova cita tal batismo rapidamente numa carta de 1554, a qual serviu de fonte para Fróis escrever sobre o assunto na sua História de Japam.

Tal batismo, contudo, permaneceu um caso isolado dentre as elites por cerca de dez anos e pouco ajudou na conversão da população local. Como vimos anteriormente, em 1558 os missionários foram obrigados por Matsūra Takanobu a deixar Hirado e a fechar temporariamente a missão no local.

O próximo fidalgo a se converter foi o kokujin Ōmura Sumitada ${ }^{191}$, em 1563. Tal batizado foi extensamente relatado nas epístolas de alguns jesuítas, que se preocuparam em classificar tal conversão como verdadeira e ponderada da parte dos padres e Sumitada, a partir de então Dom Bartolomeu, como um fervoroso e sincero cristão. Fróis relatou que:

(...) parecendo ao padre [Cosme de Torres] que, pelas pregações que tinha ouvido, estaria bem instruído, e que sabia já bem a doutrina, e tinha muita luz e conhecimento da fé, lhe pareceo em o Senhor que convinha dar-lhe o baptismo. ${ }^{192}$

Sem julgar as verdadeiras intenções de dom Bartolomeu de Omura ao se converter, a verdade é que ele sofria pressões pelas suas terras por diversos lados. $\mathrm{O}$

\footnotetext{
${ }^{190}$ Francisco Cabral. Carta aos irmãos da Companhia de Jesus em Portugal. 09 de setembro de 1576. In: GARCIA, José Manuel (ed.), op. cit., p. 357.

${ }^{191}$ Lembrando que parte da historiografia o consagra como primeiro daimyō converso, muito embora nessa época ele não passasse de um kokujin, senhor de terras menores. Por ser segundo filho do daimyō de Arima foi adotado por Omura Sumiaki, após uma aliança entre as duas casas.

${ }^{192}$ FRÓIS, Luis, História de Japam, volume I, Lisboa: Biblioteca Nacional de Lisboa, 1976 (1597), p. 282.
} 
filho natural de seu pai adotivo, Gotō Matahachiro, dois de seus cunhados, senhores de Isahaya e de Fukahori, Matsūra Takanobu de Hirado, seu irmão Arima Yoshisada e ainda o poderoso sengoku-daimyō de Saga, muito mais poderoso que todos os de Hizen, investiam militarmente contra ele de tempos em tempos ${ }^{193}$.

Os missionários ajudaram Bartolomeu a abastecer-se de material para a guerra e proporcionaram certa prosperidade comercial pelas transações com os portugueses no porto de Yosekura (e posteriormente de Nagasaki) em Omura, na província de Hizen. Sua família, no entanto, só se converteu em 1570 e seus vassalos em 1574.

Embora na História de Luis Fróis e algumas das suas cartas, assim como das de Cosme de Torres, Bartolomeu tenha sido descrito como bom cristão, Cabral e Valignano procuraram não se iludir muito. Cabral explicitamente afirmou em uma carta que dom Bartolomeu se fizera cristão "por se ver no aperto que teve por se alevantarem os navios a seus portos de que teve sempre tanto interesse" ${ }^{194}$. Já Valignano se mostrava cético quanto aos fidalgos conversos das regiões portuárias que os navios portugueses frequentavam, como poderemos ver ao analisar sua obra Sumario de las Cosas de Japon (1583).

A seguinte figura de relevo dentre a elite japonesa a converter-se foi Takayama Ukon. Batizado como Justo, possui grande notoriedade na história dos cristãos japoneses do século XVI e XVII por jamais ter apostatado e preferir posteriormente, já no governo Tokugawa, exilar-se a abandonar sua fé.

Importante membro da elite samurai da região da central do Japão (Miyako), foi Justo quem intercedeu junto a casa Oda para que os missionários tivessem sua primeira audiência com o líder Oda Nobunaga, em 1569.

As conversões de possuidores do título de daimyō, portanto, ocorreram todas no superiorato de Francisco Cabral. Em Hizen, o daimyō Arima Yoshisada foi batizado em abril de 1576, como Dom André pelo padre Gaspar Coelho. Alguns familiares seus se converteram, mas o herdeiro, Arima Harunobu, não o fez de imediato. Após a morte de seu pai ${ }^{195}$ ele ainda expulsou os missionários de seu território que só voltaram em 1580 ,

\footnotetext{
${ }^{193}$ RIBEIRO, Madalena Teotónio Pereira Bourbon, A Nobreza Cristã de Kyūshū...

${ }^{194}$ Francisco Cabral. Carta ao Geral da Companhia. 20 de novembro de 1583. In: CORREIA, Pedro Lages Reis, op. cit, (2007), p. 74.

${ }^{195}$ Não se sabe ao certo a data da morte de dom André, mas acredita-se que foi ainda em 1576.
} 
graças à intervenção do padre visitador Alexandre Valignano ${ }^{196}$ que comprometeu significativa parte das finanças da missão para providenciar mantimentos, salitre e pólvora para que Harunobu pudesse se defender do poderoso daimyō Ryūzoji Takanobu. Neste mesmo ano, ele e outros dois irmãos foram batizados por Valignano ${ }^{197}$. Os jesuítas puderam, então, voltar a Arima e retomar as conversões na região. ${ }^{198}$

No arquipélago de Amakusa (dividido em cinco "feudos” principais) os jesuítas iniciaram a pregação somente em 1571 no maior feudo (chamado também de Amakusa), após uma tentativa fracassada de pregar em Shiki, em 1566. No mesmo ano que entraram em Amakusa, Francisco Cabral batizou seu senhor, Hisatane. A conversão convenceu pouco, uma vez que sua família só se converteu em 1577 e só a partir de então os jesuítas ganharam autorização para batizarem as pessoas da região e fundar ali duas casas.

Por fim, a grande conversão ocorrida durante o superiorato do padre Cabral: Otomo Yoshishige, pai do já referido Chikaie (Sebastião). Batizado somente em 1578, como dom Francisco, Yoshishige é frequentemente citado por Cabral nas suas cartas como um grande protetor da cristandade do Japão. Segundo Cabral, mesmo quando ainda era "gentio", Yoshishige ajudara os missionários desde a fundação da missão de Funai, em 1553, por Baltazar Gago e João Fernandez ${ }^{199}$. Em 1557, foi fundada ainda outra missão em Hakata, território pertencente também à Yoshishige e em 1565 em Usuki, local onde ele residia desde 1562.

\section{O PAPEL DAS ELITES JAPONESAS NA MISSÃO}

Como pudemos perceber, o envolvimento das elites japonesas com os jesuítas só foi minimamente significativo a partir do segundo superiorato. Contudo, é essencial frisar que os missionários só conseguiram se aproximar da elite guerreira, denominada buke. A nobreza cortesã, denominada $k u g e^{200}$, teve pouco contato com os jesuítas e não

\footnotetext{
${ }^{196}$ Chegou ao Japão em 1579 pela primeira vez.

${ }^{197}$ Seu nome de batismo é Protásio.

${ }^{198}$ RIBEIRO, Madalena Teotónio Pereira Bourbon, op. cit.

${ }^{199}$ Francisco Xavier encontrara-se com Yoshishige durante sua estadia no Japão, mas acabou por não fundar nenhuma missão em seu território por falta de missionários. Acabou dando preferência para a fundação da missão em Yamaguchi que fechou em 1557 pela invasão de Mori Motonari e só foi recuperada temporariamente em 1586.

${ }^{200}$ Os jesuítas tinham total noção dessa divisão entre as elites japonesas. No "Vocabulario da Lingoa de Iapam com adeclaração em Portugues, feito por alguns padres e irmãos da Companhia de Iesu", de 1603, o verbete cugue tem como definição "Família dos cugues que servem a Dairi [imperador]", já o
} 
se envolveu com o cristianismo. A distância física, consequencia do seu confinamento na corte imperial, assim como a indiferença para com a religião cristã - que negava a descendência divina de tal nobreza - acabou por mantê-los distantes de qualquer negócio com os jesuítas. Mesmo em troca de favores, os kuge sempre se recusaram a interceder a favor dos cristãos. Em carta de 1571, Fróis ${ }^{201}$ conta que pediu através de Vatadono - um samurai influente da região de Miyako - para que alguns nobres ajudassem-no a ser recebido pelo imperador e em troca Vatadono teria oferecido o restabelecimento de alguns impostos que lhes foram tirados anteriormente por Nobunaga, mas os nobres recusaram-se a fazê-lo. ${ }^{202}$

Contudo, era inegável que o favorecimento por parte da elite guerreira seria bem mais proveitoso para o fortalecimento da missão, uma vez que possuíam um poder político muito maior. A recusa por parte da nobreza kuge em recebê-los não se tornou, portanto, um obstáculo para a evangelização no Japão.

Por outro lado, a estratégia em se aproximar das elites guerreiras foi bastante presente no caso japonês, principalmente a partir do superiorato de Cabral. Já na sua carta de 1571 ao Geral da ordem, ele deixara clara tal orientação:

Quanto ao proceder da Christandade destas partes como ja tenho escrito a Vossa Reverencia os milhores apostolos que qua há são os Senhores e tonos ${ }^{203}$ porque como cummumente vivão das terras e rendas que lhes elles dão e todos sejão tão pobres que não tem mais que ho que a terra lhes da com se cultivar dependem tanto dos senhores que não conhecem outro deus e por isso se lhes dizem que sejam de huma lei ho são facilmente e deixão commumente há que tinhão e se ho senhor não lhes da licença para tomarem outra por muito que o desejasem não a tomão. ${ }^{204}$

Além disso, ele afirmava que, com exceção de alguns escolhidos por Deus, os pobres facilmente abandonavam sua fé caso seu senhor pedisse, já as pessoas da elite,

buqe tem como definição: "Família de soldados ou cavaleiros cuja cabeça é o [ilegível] que tembém se diz xogum, e é capitão geral da milícia del Rei de Japão".

${ }^{201}$ Luis Fróis. Carta ao provincial da Índia Antônio Quadros. 28 de setembro de 1571. In: GARCIA, José Manuel (ed.), op. cit., p. 313v.

${ }^{202}$ PINTO, Ana Fernandes. Japanese Elites as Seen by Jesuit Missionaries: Perceptions of social and political inequality among the elites. Bulletin of Portugueses/Japanese Studies, Universidade Nova de Lisboa, vol. 1, dez-2001, p. 29-43.

${ }^{203}$ Refere-se aos fidalgos possuidores de terras. No "Vocabulario da Lingoa de Iapam com adeclaração em Portugues, feito por alguns padres e irmãos da Companhia de Iesu" (1603) a definição de tono é dada como: "Senhor de alguma terra, ou que tem criados ou renda".

${ }^{204}$ Francisco Cabral. Carta ao Geral da Companhia. 05 de setembro de 1571. In: CORREIA, Pedro Lages Reis, op. cit., (2007), p. 69. 
"como tem mais intendimento jeralmente e tomão mais gerais as cousas de Deus tem muito mais dificuldade de os fazer retroceder" ${ }^{205}$. Assim sendo, os jesuítas deveriam dar uma prioridade estratégica à conversão da elite guerreira ou ao menos à manutenção de uma boa relação com os mesmos.

O Padre Vsitador das Índias Orientais, Alexandre Valignano, já na sua primeira visita ao arquipélago confirmou tal orientação e estratégia, apelando para o mesmo argumento que Cabral. Na sua obra Cerimonial ${ }^{206}$ que escreveu para os jesuítas que trabalhavam na missão japonesa (terminado ao fim da visita em 1583), afirmava que os padres e irmãos: "principalmente ham de trabalhar pera fazer familiares e bons Christãos as cabeças e pessoas principaes, porque, como estes forem amorosos e bons, o serão facilmente todos os outros". ${ }^{207}$

O método de conversão vertical, baseado nos batismos em massa autorizados ou até ordenados pelos daimyō conversos acabou prevalecendo e foi corroborado posteriormente pelo Visitador na Consulta promovida em Nagasaki no ano de 1581. As primeiras conversões em massa ocorreram somente na década de 1570 , no superiorato de Cabral, nos domínios de Ōmura e Arima.

Mesmo adepto de tal método, Cabral não foi ingênuo quanto às verdadeiras intenções dos daimyō conversos. Nesta mesma carta ao Geral da ordem ele afirmou:

(...) a principal causa destes senhores quererem a lei de Deus em sua terra e desejarem padres he ho interese temporal que tem en especial os que tem portos por onde venhão navios com cujos direitos e frequência de mercadores se vai emposando sua terra. ${ }^{208}$

O próprio Visitador Valignano sabia disso e, como veremos, procurará dar preferência à missão da região de Miyako, mesmo sendo esta a menor do Japão, pelos senhores de lá não terem interesses temporais na conversão, uma vez que os navios portugueses não chegavam até lá.

Tal estratégia de aproximação da elite não foi, contudo, orientação exclusiva de Cabral ou de Valignano. O próprio fundador da Companhia de Jesus, Ignacio de Loyola

\footnotetext{
${ }^{205}$ Francisco Cabral. Carta ao Geral da Companhia. 05 de setembro de 1571. In: ibid., p. 70.

${ }^{206}$ Alexandre Valignano. Advertimentos e Avisos Acerca dos Costumes e Catangues do Jappão. 1583. In: SCHÜTTE S.J., Giuseppe Franz. Il Cerimoniale per i missionari Del Giappone, Roma: Instituto Grafico Tiberino, 1946.

${ }^{207}$ Idem, pag. 168.

${ }^{208}$ Francisco Cabral. Carta ao Geral da Companhia. 05 de setembro de 1571. In: ibid., p. 70.
} 
(1491-1556), delineou tal estratégia. Nas Constituições, tal orientação aparece explicitamente:

(...) sendo o bem tanto mais divino quanto mais universal, devem-se preferir as pessoas e os lugares cujo aproveitamento possa ser causa de que o bem se estenda a muitos outros sob a sua influência ou autoridade. Por este mesmo motivo do bem universal, deve-se ter como mais importante o auxílio espiritual aos homens de influência, ou que exercem funções públicas (quer sejam leigos, como os príncipes, senhores, magistrados, e juízes, quer ser sejam eclesiásticos, como os prelados), bem como as pessoas eminentes pelo saber e autoridade. ${ }^{209}$

Assim, a orientação para toda a Companhia, independente do seu local de ação, era justamente a aproximação com a elite local, não por um maior peso espiritual destas pessoas, mas sim por uma maior influência temporal dos mesmos, capaz de auxiliar o crescimento da missão.

\section{A MISSÃO SOB CABRAL}

Assim que chegou ao Japão, Cabral assumiu o cargo de novo superior universal da missão japonesa tendo encontrado Torres já muito debilitado na ilha de Shiki ${ }^{210}$. Reuniu então alguns dos padres que se encontravam em Shimo e promoveu uma Consulta, apenas um mês após sua chegada. Estavam presentes nela os padres: Cosme de Torres (apesar de estar com saúde extremamente fragilizada conseguiu presenciar a Consulta), Gaspar Vilela, Baltasar da Costa, Alessandro Vallareggio, Melchior de Figueiredo, Giovani Battista de Monte, Organtino Gnnechi-Soldo, Baltasar Lopes e os irmãos: Luís de Almeida e Jácome Golçalves. ${ }^{211}$

Fróis, na sua História de Japam, afirmou que Cabral promoveu tal encontro para comunicar-lhes as "ordens vindas do provincial da Índia”, contudo não explicita quais. Cabral por sua vez contou na sua carta de 1571 quais eram as tais ordens:

[O padre Visitador $\left.{ }^{212}\right]$ mandome expressamente que de todo se tirassem qua as sedas e fausto e a [chatinaria] se moderasse de maneira (...) que não ouvesse mais que a boamente podese gastar para conforme a pobreza da Companhia nos sostentassemos. ${ }^{213}$

\footnotetext{
209 Constituições da Companhia de Jesus, VII, cap. 3, § 622. In:LOYOLA, Ignácio de (santo), Constituições da Companhia de Jesus e normas complementares, São Paulo: Loyola, 1997.

${ }^{210}$ FRÓIS, Luis, História de Japam, volume II,Lisboa: Biblioteca Nacional de Lisboa, 1981 (1597).

${ }^{211}$ CORREIA, Pedro Lages Reis, op. cit., (2007).

${ }^{212} \mathrm{O}$ padre Visitador citado por Cabral é Gonçalo Álvares, antecessor de Alexandre Valignano.
} 
Cabral afirmou na mesma carta, contudo, que todos foram contra suas ordens, com exceção do padre João Batista e de Cosme de Torres. Este, por sua vez, teria dito que tais costumes foram se introduzindo dentre os missionários contra sua vontade. Os outros padres, por sua vez:

Me dizião que tirando as sedas era cerrar a porta à conversão destas partes porque como os japões não olhavam senão para ho exterior como não trouxéssemos sedas e andasemos vestidos de preto que não somente nenhum senhor gentio mas nem os christãos nos verião e outros incomvenientes fundados no amor próprio e demasiada soltura que já estava introduzida e nem bastava dar lhes rezões. ${ }^{214}$

Fróis não esteve presente na Consulta por estar em Miyako. Cabral, contudo, contou que quando soube que tanto Fróis quanto Organtino (que após chegar ao Japão acompanhado de Cabral foi para a região de Miyako trabalhar junto de Fróis) usavam quimonos de seda que teriam ganhado de um cristão da região, escreveu para ambos pedindo para que não usassem tal roupa, pois seria contra a "obediência e pobreza" professada por eles, "mas a resposta que tive disto foi de cada hum sua carta em que me punhão as mãos e tratavão como eu mereço". 215

Tal comportamento parece bastante estranho de dois jesuítas para com seu superior, mas independente de Cabral ter ou não exagerado na tinta o importante a ser notado é que Fróis não concordara com tal ordem e fazia uso do tecido, proibido inclusive por ordem do então visitador. Não é à toa, portanto, que Fróis não tenha especificado quais eram as tais ordens trazidas por Cabral na sua História de Japam.

A carta de Cabral, transcrita em parte acima, data de um ano após a sua chegada. Temos notícias, contudo, que apesar da recusa dos padres e irmãos, citada pelo superior em sua carta, a ordem permaneceu até o fim de seu governo e inclusive foi confirmada por Valignano após sua primeira visita. Em uma passagem de sua História, Fróis contou de quando foram visitar Nobunaga em Mino no ano de $1572,{ }^{216}$ o general teria dito que

\footnotetext{
${ }^{213}$ Francisco Cabral. Carta ao Geral da Companhia. 05 de setembro de 1571. In: CORREIA, Pedro Lages Reis, op. cit., (2007), p. 70.

${ }^{214}$ Francisco Cabral. Carta ao Geral da Companhia. 05 de setembro de 1571. In: ibid, p. 71.

${ }^{215}$ Francisco Cabral. Carta ao Geral da Companhia. 05 de setembro de 1571. In: ibid, p. 71.

${ }^{216}$ Estavam presentes neste encontro Francisco Cabral, Luis Fróis e dois irmãos japoneses.
} 
queria dar de presente aos padres vestidos de seda, mas parecia pouco próprio já que só vestiam "pano preto" 217.

Sabemos que Cabral criticava o uso de seda para qualquer fim, mesmo quando fossem visitar personalidades da elite. Ele relatou inclusive que quando partiu de Miyako para ir ver Nobunaga, todos pediram a ele que mudasse seu traje e vestisse seda senão algo de muito ruim poderia acontecer, mas ele "quis ir mais confiado em Deos e na obediência, pola qual fazia aquella viagem, que nos meos que me davam" ${ }^{218}$. Assim foi com sua "roupeta e coroa" e nada aconteceu a ele e até Nobunaga e o Cubosama 219 fizeram honras e favores, e todos, cristãos e gentios, ficaram admirados, estando ele pobremente vestido.

As tais honras citadas foram relatadas em outra carta e até mesmo por Fróis, na sua História, onde conta que Nobunaga teria dado uma carta a eles na qual pedia para que todos os senhores os abrigassem bem e todos para quem os padres mostravam as cartas ficavam admirados por Nobunaga não fazer isso com ninguém. ${ }^{220}$

Outra mudança promovida durante o superiorato de Cabral diz respeito à ênfase dada ao estudo da língua japonesa pelos padres e irmãos. Cabral jamais afirmara que tal estudo seria irrelevante, mas ao contrário de Cosme de Torres, que enfatizou por diversas vezes o tempo dedicado ao estudo do idioma, Cabral não faz menção ao assunto. Tal falta poderia não ser uma evidência tão certa, uma vez que sabemos que parte das cartas perdeu-se, não fosse pela contundente crítica feita nos anos posteriores por Alexandre Valignano.

Numa correspondência com o Geral da Companhia, Claudio Acquaviva, em $1595^{221}$, Valignano afirmou que um dos princípios que Cabral tinha no governo da missão no Japão era:

Que la lengua japónica ni se havia nunca de aprender bien por los nuestros, a lo menos para poder llegar a predicar em japón, ni se havia de aprender por arte. Y assí em treze

\footnotetext{
${ }^{217}$ FRÓIS, Luis, História de Japam, volume II, Lisboa: Biblioteca Nacional de Lisboa, 1981 (1597).

${ }^{218}$ Francisco Cabral. Carta a um secular de Kochinotsu. 29 de setembro de 1572. In: GARCIA, José Manuel (ed.), op. cit., p. 338.

${ }^{219}$ Refere-se ao então xogum.

${ }^{220}$ FRÓIS, Luis, História de Japam, volume III, Lisboa: Biblioteca Nacional de Lisboa, 1981.

${ }^{221}$ Valignano afirma não ter falado antes das coisas que contará na carta por ter retirado Cabral do cargo de superior do Japão e não saber qual era sua influência na Índia.
} 
años que fue superior de Japón, ni él la aprendió (...), ni procuro que se heziesse alguna diligencia para se reduzir a arte. ${ }^{222}$

Cabral, por sua vez, apesar de não afirmar que tais estudos deveriam ser abandonados, demonstrou ter outras prioridades por ser o japonês uma língua de grande dificuldade para um europeu aprender. Ao defender que os nativos é que deveriam fazer a pregação ele explica: "la predicación sino fuere de los naturales no puede aver de aquí a muchos annos quién lo pueda saber porque es la lengua del Jappon tan dificultosa".223

A crença de que os europeus demorariam muitos anos para conseguirem falar japonês teria, portanto, feito com que o superior negligenciasse tais estudos. Sua opinião, por sua vez, não era infundada uma vez que mesmo Luis Fróis, considerado o melhor conhecedor do idioma japonês até então, não se arriscava a abordar não conversos em público e mesmo dentre os cristãos demonstrava dificuldade em se comunicar. $^{224}$

O primeiro missionário a ter um bom conhecimento do japonês foi o padre João Rodrigues (1561-1633) que possui uma história ímpar dentre os missionários jesuítas. Tendo chegado ao Japão com apenas 16 anos (em 1577), iniciou seu noviciado em Nagasaki, tendo, portanto, começado seus estudos de japonês ainda garoto. Posteriormente foi chamado por Toyotomi Hideyoshi para ser intérprete na sua corte onde, a partir de então, ficou conhecido como João Rodrigues Tçuzu, ou seja, o intérprete. Rodrigues foi também o responsável pela confecção da primeira gramática do japonês em português, cuja primeira edição data de 1608 .

\section{O VISITADOR ALEXANDRE VALIGNANO}

Alexandre Valignano nasceu em 1539, em Nápoles na Itália. Antes de entrar na Companhia, o futuro Visitador não teve aquilo que poderíamos chamar de uma vida regrada. Proveniente de uma família nobre da região de Nápoles, ele envolveu-se, em 1562, numa briga com uma vizinha, o que lhe resultou em um ano e meio de prisão. Afirmando-se arrependido de tal episódio ele pediu, em 1566, para ser admitido na

\footnotetext{
${ }^{222}$ Alexandre Valignano. Carta ao Geral da Companhia Claudio Acquaviva. 23 de novembro de 1595. In: WICKI S.J., Joseph (ed.). Documenta Indica (1595-1597), v. XVII, Intitutum Historicum Societatis Iesu, Roma, Via dei Penitenzieri, 1988, p. 263-264.

${ }^{223}$ Francisco Cabral. Carta ao Geral da Companhia. 09 de setembro de 1576. In: CORREIA, Pedro Lages Reis, op. cit., (2007), p. 60 nota 54.

${ }^{224}$ CORREIA, Pedro Lages Reis, ibid.
} 
Companhia. O então Geral da Companhia, Francisco Borja, aceitou que ele professasse os votos simples no ano seguinte e ele então iniciou seus estudos no colégio Romano, sendo já formado em direito canônico. ${ }^{225}$

Em fevereiro de 1570, professou os três votos solenes requeridos para ser elevado ao sacerdócio e, em 1572, foi nomeado reitor do colégio de Macerata. No ano seguinte, Valignano manifestou seu desejo de ir à Índia e o então Geral da Companhia, Everardo Mercuriano, o nomeou Visitador das Índias Orientais. Ele professou então o quarto voto e no ano seguinte chegou à Goa. ${ }^{226}$

O cargo de Visitador era nomeado de tempos em tempos diretamente pelo Geral da Ordem e sua função era representá-lo em uma ou mais províncias. Possuía, portanto, autoridade sobre todos da província mandada, inclusive o provincial. O Visitador deveria inspecionar a, ou as, províncias que o Geral lhe ordenasse.

\section{A VISITA AO JAPÃO}

A primeira visita de Valignano ao Japão foi em 1579, tendo esta durado até 1582. ${ }^{227}$ Assim que chegou ao arquipélago decidiu promover algumas Consultas ${ }^{228}$. Elas aconteceram em Usuki (Bungo) em outubro de 1580, Azuchi (Miyako) em julho de 1581 e Nagasaki (Shimo) em dezembro de 1581. Essas Consultas foram documentadas em Atas e em janeiro de 1582, Valignano escreveu as "Resoluciones" para as vinte e uma perguntas discutidas nas mesmas e ordenou que tanto as perguntas quanto suas Resoluciones deveriam ser guardadas em todas as casas de padres e irmãos e as ordens obedecidas "hasta que nuestro Padre General mande sobre ellas outra cosa"229.

Já na primeira das consultas, em Usuki, o antagonismo entre as idéias do então superior do Japão - Francisco Cabral - e Valignano ficou claro. Estavam presentes na mesma, além dos dois, os padres: Lourenço de Mexia ${ }^{230}$, Fróis, Figueredo, Monte,

\footnotetext{
225 TALADRIZ, J. C. Alvarez, Monumenta Nipponica Monographs, Tóquio: Sophia University, v. 9, 1954.

${ }^{226}$ MORAN, J. R..The Japanese and the Jesuits.Alessandro Valignano in sixteenth century Japan, Londres, 1993.

${ }^{227}$ Ele faz outra visita de 1590 a 1592 e uma terceira de 1598 a 1603 . Trataremos somente da primeira das visitas na presente dissertação.

${ }^{228}$ Uma vez que a missão encontrava-se espalhada em diversos locais do arquipélago Valignano escolhe três locais para promover as Consultas, de forma que todos os jesuítas pudessem estar presente em pelo menos uma delas.

${ }^{229}$ Alexandre Valignano. Resoluções sobre a Consulta do Japão. 06 de Janeiro de 1582. In: TALADRIZ, José Luis Alvarez (ed.), op. cit., p. 162*.

${ }^{230}$ Lourenço de Mexia (1539-99). Foi para o Japão a pedido do Geral da Ordem para acompanhar Valignano e servir-lhe de monitor. Ele volta para Macau em 1582, ao fim da primeira visita de Valignano.
} 
Ramón, Prenestino, Rebello e Laguna. Trataram do governo interno da Companhia, de como reduzir ao máximo possível as residências distantes de colégios, de maneiras para suprir a falta de obreiros e com particular ênfase se considerou a necessidade de se implementar um método de adaptação do modo de proceder dos missionários à vida japonesa $^{231}$, algo que já era desejado pelos missionários desde o primeiro superiorato, como vimos no capítulo anterior.

Valignano teria ficado tão preocupado com o andamento da missão sob a direção de Cabral, após tal consulta, que escreveu logo em seguida uma carta ao padre Geral da Companhia expondo cinco "princípios" que ameaçavam arruinar o trabalho da Companhia no Japão.

No primeiro desses princípios Valignano fez uma crítica contumaz à Cabral afirmando que o modo de governo da missão no Japão seria maléfico por deixar a Companhia e sua cristandade sob o arbítrio pessoal de apenas um: o superior. Este, por sua vez, não teria, nas palavras de Valignano: “conocimiento de las Constituiciones ${ }^{232}$, de las Reglas del Provincial, de las del Rector, de la ordenación del noviciado ni de otras reglas". ${ }^{233}$ Além disso, tal governo corria "sin consulta y con mucho império", o que teria causado grandes desordens que não poderiam ser mais toleradas, principalmente agora que a cristandade havia crescido.

Além disso, Valignano reclamou da desunião presente entre pregadores europeus e os irmãos japoneses. Estes estariam sendo tratados com aspereza o que daria a impressão de que eram empregados pouco amados e não irmãos, mesmo sendo tão necessários para a propagação da fé no Japão. A união entre cristãos nativos e europeus foi uma preocupação constante na obra e correspondência do Visitador. No seu Cerimonial Valignano dedicou um capítulo para tratar da maneira como os missionários deveriam agir para que se fizessem familiares dentre os japoneses $\operatorname{conversos}^{234}$. Segundo ele, isso era de suma importância para o engrandecimento da missão.

A forma de recebê-los na Companhia estaria errada também, uma vez que não havia noviciado ou provação alguma para eles, muito embora fossem eles que

\footnotetext{
${ }^{231}$ TALADRIZ, J. C. Alvarez, op. cit.

${ }^{232}$ As referências às Constituições da Companhia de Jesus dentre os missionários atuantes no Japão iniciam-se justamente com essa querela entre Cabral e Valignano.

${ }^{233}$ Alexandre Valignano. Carta ao Geral da Companhia Claudio Acquaviva. 27 de outubro de 1580. In: TALADRIZ, J. C. Alvarez, op. cit., p. 133*.

${ }^{234}$ Capítulo 2 "Do modo que se há de ter pera fazer familiares os christãos".
} 
pregassem e convertessem a população, não sabiam as Regras da Ordem nem o Instituto e não tinham acesso a livros. A única coisa que sabiam era um Catecismo que decoravam e repetiam "como papagaios", nas palavras do próprio Visitador. A idéia de que eles não precisariam saber de ciência alguma era, contudo, corrente dentre os padres e Valignano criticou tal postura no quinto princípio que estaria ameaçando a Companhia e a cristandade no Japão. ${ }^{235}$

As mudanças propostas por Valignano iniciaram ainda durante sua primeira visita. Ele ordenou que se traduzisse para o japonês o Exame - segundo as Constituições da Companhia - suas Regras e os Exercícios Espirituais de Loyola, sendo que todo aquele que quisesse entrar na Companhia deveria fazê-los inteiramente. Além destes, Valignano indicou obras a serem traduzidas para uso tanto dos irmãos quanto leigos japoneses, estas eram Contemptus mundi e Imitación de Cristo, ambas de Fray Luis de Almeida. O aprendizado do idioma nativo por parte dos europeus foi enfatizado, tendo o Visitador ordenado a confecção de um Vocabulário e alguns Diálogos em japonês, além do aperfeiçoamento da $\operatorname{Arte}^{236}$ já existente.

A redação do Regimento para os Padres que estão nas residências de Japão, feito ultimamente polo Pe. Visitador no mes de Novembre no anno de 1581, assim como das Resoluções das Consultas, implementavam grandes mudanças que seriam seguidas pelos jesuítas nos anos seguintes. Tais mudanças foram defendidas e melhor explicadas na obra que Valignano escreveu após sua primeira visita ao Japão Sumario de las Cosas de Japon (1583) e será analisada separadamente aqui.

Tais mudanças parecem ter dado uma orientação mais clara à missão, coisa que até então não havia acontecido, como nos conta Fróis em um trecho da sua História:

Deixou mais o Pe. Vizitador ordenado o modo que havíamos de ter acerca dos costumes e cerimônias e maneira de proceder da terra, couza muito desejada dos mesmos japões, para se guardar em nossas cazas e nos podermos melhor conformar com eles; e que não é de pouca importância para sermos bemquistos e tidos em boa opinião entre elles, porque, como os costumes e cerimônias desta terra são tão diferentes e contrários dos que se usam em Europa, e athé agora não tínhamos huma certa ordem que houvéssemos de guardar acerca delles, além de isto causar huma certa confusão entre nós, não

\footnotetext{
${ }^{235}$ Alexandre Valignano. Carta ao Geral da Companhia. 27 de outubro de 1580. In: TALADRIZ, J. C. Alvarez, op. cit.

${ }^{236}$ Gramática.
} 
sabendo como nos havíamos de haver nos costumes e modo de tratar com elles, se seguiam outros inconvenientes mayores, ficando muitas vezes os japões offendidos e cauzando huma certa divisão de ânimos e perda de muito frutto pela contrariedade que havia dos nossos e dos seos costumes. ${ }^{237}$

\section{O RESULTADO FINAL DO ANTAGONISMO ENTRE CABRAL E VALIGNANO}

Em 1581, Cabral pediu a Valignano para deixar a chefia da missão. Ele alegou problemas de saúde que parecem ter sido reais conforme os relatos de outros missionários, como Lourenço Mexia que escreveu em uma carta de 1580 ao Geral da Companhia, onde afirmava que Cabral teria passado grande parte do ano sofrendo com febres e calafrios que colocaram sua vida em perigo ${ }^{238}$. Fróis também mencionou a saúde fragilizada de Cabral na sua História:

E porquanto o Pe. Francisco Cabral havia muitos anos que era superior nestas partes, e além de seus muitos trabalhos e idade, era muitas vezes oprimido de diversas enfermidades, fazendo ele instância ao padre Vizitador que o eximisse desta obrigação para com mais comodidade sua se poder e entender em sua saúde. ${ }^{239}$

Valignano aceitou seu pedido e colocou o padre Gaspar Coelho no comando da missão. O Visitador tinha a intenção de transformar a missão japonesa em província separada da Índia, mas preferiu adiar seus planos após a saída de $\mathrm{Cabral}^{240}$. Gaspar Coelho - português, professo dos três votos solenes - foi descrito por Valignano como:

(...) buen religioso, virtuoso y prudente y activo y tiene ánimo y es más fácil y dócil que el outro [Francisco Cabral], aunque no es, a mi juicio, de tanta prudencia ni de tanto negocio; pero, después del outro, es el más apto sujeto que tenemos aqui para gobernar $^{241}$.

Ao deixar o cargo de superior, Cabral ficou por mais dois anos no Japão, em Usuki, a serviço espiritual de D. Francisco Otomo e no cuidado da cristandade de Notsu, em Bungo. Em 1583, partiu para Macau após ser nomeado reitor do colégio de São Paulo no lugar de Pedro Gomez. Em janeiro de 1587, retornou para Índia onde

\footnotetext{
${ }^{237}$ FRÓIS, Luis, História de Japam, volume III, Lisboa: Biblioteca Nacional de Lisboa, 1981 (1597), p. $177-178$

${ }^{238}$ Lourenço Mexia. Carta ao Geral da Companhia. 20 de outubro de 1580. In: GARCIA, José Manuel (ed.), op. cit.

${ }^{239}$ FRÓIS, Luis, História de Japam, volume III, Lisboa: Biblioteca Nacional de Lisboa, 1981 (1597), p. 177.

${ }^{240}$ TALADRIZ, J. C. Alvarez, op. cit.

${ }^{241}$ Apud: ibid., p. 170*.
} 
passou a trabalhar como superior da casa jesuíta de Goa até 1592 e depois novamente de 1600 até o ano de sua morte em 1609. Neste ínterim, de 1593 a 1596, foi provincial da Índia.

Apesar de seus problemas de saúde Cabral ainda viveu por um bom tempo desempenhando cargos de importância na Companhia. Fica claro, portanto, que a provável razão de sua saída do Japão foi seu antagonismo com Valignano. Este, por sua vez, já em outubro de 1580, afirmou em uma de suas cartas:

Me dava mucha angustia porque la penuria de los obreros y la dificultad deste gobierno no me hazia cosa fácil de mudarlo poniendo outro em su lugar porque no via a quien pudiesse seguramente encomendar para este negotio y cierto está que cayendo el en las cosas es el mejor subjecto y mas apto para el gobierno de quantos aqui hay. ${ }^{242}$

Cabral por sua vez não abriu mão das idéias que tanto incomodavam Valignano e a única saída foi a sua substituição por Gaspar Coelho.

\section{A PROPOSTA DE VALIGNANO PARA O JAPÃO E O SUMÁRIO}

\section{A Obra}

Datado de 1583, Valignano iniciou seu Sumario de las Cosas de Japón ainda no arquipélago, provavelmente por volta de junho de 1580, e o terminou em Cochim em 1583, segundo o historiador Jorge Alvarez-Taladriz. ${ }^{243}$

Escrita em espanhol ${ }^{244}$ a obra é dividida em trinta capítulos além do proêmio e da conclusão. Os três primeiros capítulos são descritivos do Japão ${ }^{245}$ e foram transcritos integralmente para a sua obra Historia Del Principio y Progresso de la Compañia de Jesús em las Indias Orientales, conhecida como Sumário Índico, também datada de 1583. Taladriz acredita que essa parte da obra foi escrita ainda no Japão entre outubro de 1580 e meados de 1581 .

Embora ambas as obras tenham sua versão final datada de 1583, pode-se perceber que o núcleo do Sumário Índico é anterior ao do Japão. Valignano fez questão

\footnotetext{
${ }^{242}$ Alexandre Valignano. Carta ao Geral da Ordem. 27 de outubro de 1580. . In: CORREIA, Pedro Lages Reis, op. cit., (2007), p. 64, nota 66.

${ }^{243}$ TALADRIZ, J. C. Alvarez, op. cit.

${ }^{244}$ Valignano afirmou em carta de setembro de 1577 ao Geral Mercuriano, que falava melhor o português e o espanhol do que o italiano. Contudo, preferia escrever em espanhol por ser o português menos compreendido em Roma.

${ }^{245}$ Capítulo I: De la descripción, costumbres e cualidades de Japón; Capítulo II: De algunas otras extrañas costumbres de los japones; Capítulo III: De la religión e sectas de los japones.
} 
de escrever uma obra dedicada exclusivamente à missão japonesa para demonstrar a profunda diferença existente entre a cultura japonesa e européia ocidental. Ainda que o Sumário Índico também tratasse da missão japonesa, o fazia de maneira superficial, apenas como uma das residências da atividade jesuíta nas Índias Orientais.

Os capítulos quatro e cinco do Sumário do Japão falam da situação da missão ${ }^{246}$ e os outros de questões de ordem prática que envolviam o modo de governo que se deveria empregar na missão.

O Sumário era direcionado às autoridades da Companhia em Roma e no Japão e não ao público em geral. Para Taladriz: "desde o primeiro momento o Sumário se despreocupa do público geral; por esta mesma razão de ser exclui esta publicidade e nasce destinado a permanecer inédito. Isto coloca já um limite inicial à sua influência". ${ }^{247}$ Não por isso a obra foi pouco lida e divulgada tendo contado com mais de trinta edições em diversas línguas europeias. Foi o principal veículo para difusão das ideias de Valignano para o Japão que, a partir de então, passaram a ser opinião corrente na Europa, pelo menos até a rejeição final da acomodação por Roma em 1704 (confirmada posteriormente em 1742) ${ }^{248}$, após acalorados debates levantados não apenas por Valignano para o Japão, mas por outros jesuítas como Mateo Ricci na China e Roberto de Nobili na Índia ${ }^{249}$.

Pode-se dizer que o Sumário era, primordialmente, um manual de estratégia para introdução do cristianismo em uma sociedade "civilizada" - segundo os parâmetros da época - que possuía outras religiões multisseculares e sem qualquer conquista militar por parte do poder de algum reino europeu.

\section{O início da obra: o Japão e seu povo}

Já no proêmio Valignano afirmava que escrevia "un tratado próprio y más copioso de las cosas pertencientes a Japón" por três razões: primeiramente por serem os costumes do Japão tão diferentes e contrários tanto dos da Europa quanto da Índia;

\footnotetext{
${ }^{246}$ Capítulo IV: De la división de la província de Japón y de las casas y colégios y Iglesias que em ella tenemos e particularmente em las partes de Shimo; Capítulo V: De las casas y residencias de Bungo y de Miyako.

${ }^{247}$ TALADRIZ, J. C. Alvarez, op. cit., p. 196*, (tradução livre).

${ }^{248}$ RUBIÉS, Joan Pau. The Concept of Cultural Dialogue and the Jesuit Method of Accommodation: between idolatry and civilization. In: WORKSHOP JESUITS AS INTERMEDIARIES IN THE EARLY MODERN WORLD, 2001, Florença, S.N., European University Institute.

${ }^{249}$ Tais debates acabaram por fugir ao controle da Igreja que se viu impotente para controlar algumas idéias que surgiram durantes os mesmos e a saída encontrada foi a rejeição total da acomodação no século XVIII.
} 
segundo porque a missão japonesa vinha crescendo muito e não poderia mais ser entendida como uma casa acessória da Índia (lembremos que em 1581 a missão japonesa foi alçada à categoria de vice-província) e por fim para que servisse de guia para os que fossem dirigir tal missão.

O Visitador tinha total noção que as propostas que faria para a direção da missão não seriam facilmente aceitas nem entendidas pelas autoridades que permaneciam na Europa. Antecipando-se a isso ele pede:

(...) cuando en Roma se trata de Japón no extrañen las cosas que se oyen, antes se entienda que la determinación de muchas de ellas se ha de reservar para los que gobernaren a Japón, que se dien por bien hechas aunque no del todo se entiendan. ${ }^{250}$

Ele inicia então sua obra discorrendo sobre os costumes e qualidades do Japão. Embora ele afirme que vai fazer uma simples "descrição",251, fica bastante claro para o leitor que a mesma serve ao propósito de justificar seu método de evangelização dos japoneses.

A primeira coisa que ele busca fazer o leitor entender é que a missão japonesa não é uma missão qualquer, pois os japoneses não são um povo inferior, mas "exceden no solamente a las otras gentes de Oriente, mas a los nuestros de Europa" ${ }^{252}$. Ou seja, a estratégia de evangelização dos mesmos precisaria ser bem pensada já que eles poderiam exceder até mesmo os europeus em suas qualidades.

Valignano, contudo, não deixou de apontar os defeitos que os inferiorizariam perante os europeus. O segundo capítulo - "De algunas otras extrañas costumbres de los japones" - é dedicado à descrição dessas "más características" que, por sua vez, seriam "siempre comunes a toda la gentilidade". ${ }^{253}$ Tais características, no entanto, não seriam provenientes da natureza dos japoneses, que era tão boa, mas das "perversas" leis que o "demônio e os bonzos" lhes deram.

O autor enumera então as cinco piores qualidades do povo japonês - pecados sensuais, pouca fidelidade aos senhores, costume de mentir e fingir descontroladamente,

\footnotetext{
${ }^{250}$ VALIGNANO, Alexandre, Sumario de las Cosas de Japon, In: TALADRIZ, J. C. Alvarez, op. cit., p. 3.

${ }^{251}$ O primeiro capítulo intitula-se: De la descripción, costumbres e cualidades de Japón.

${ }^{252}$ VALIGNANO, Alexandre, Sumario de las Cosas de Japon, In: TALADRIZ, J. C. Alvarez, op. cit., p. 5.

${ }^{253}$ VALIGNANO, Alexandre, Sumario de las Cosas de Japon, In: ibid., p. 25.
} 
matam facilmente e sem remorso e são dados a festas e bebedeiras - sempre frisando a culpa que os bonzos têm pela introdução de tais costumes. Além disso, ele ressalta que todos os povos gentis possuíam tais características e dentre estes, incluindo os antigos romanos quando eram pagãos, os japoneses seriam os melhores. ${ }^{254}$

Embora Valignano reconhecesse que tais "defeitos" eram graves e até afetavam as qualidades dos japoneses, ele afirmava ser espantoso que, apesar da existência de tão perversas leis e ainda sofrendo com extrema pobreza e guerras contínuas, os japoneses tivessem ainda tão boas qualidades "que pueden hacer confundir a la gente de Europa". 255

Por fim, o Visitador dedica um capítulo às religiões japonesas (Capítulo III - De la religión e sectas de los japones). Ele não fez uma diferenciação clara entre o budismo e o culto aos kami, mas afirmou existir no Japão dois tipos de deuses: os kamis - que seriam deuses antigos do Japão, provenientes da família dos reis e dos kuge - e os hotokes, provenientes da China e do Sião, sendo os principais Amida e Shaka ${ }^{256}$. Este último, segundo seu relato, teria sido um filósofo que iniciara sua pregação entre os siameses e cuja doutrina fora escrita por seus discípulos. Esta, por sua vez, seria tão "confusa", que pôde ser interpretada de várias formas essencialmente conflitantes, de maneira que acabaram por se fundar diversas seitas sobre ela.

A separação entre a doutrina budista e àquela que hoje chamamos vulgarmente de xintoísta não foi percebida com clareza pelos jesuítas - muito embora tenham chegado a falar das seitas dos kamis no tratado sobre as religiões japonesas, discutido no capítulo anterior - não por qualquer ignorância da parte destes, mas justamente porque as práticas religiosas da população naquela época não faziam essa separação claramente. Mesmo após a entrada das novas seitas budistas do período Kamakura que se opunham ao sincretismo com as práticas xintoístas, tão presentes no Japão

\footnotetext{
${ }^{254}$ Valignano manteve até o fim de sua vida tal opinião. Em obra que escreveu em 1601 denominada "Libro primero del principio y progresso de la religion christiana en Jappon y de la especial providência que Nuestro Señor usa com aquella nueva Iglesia" ele reitera que "no hallo gentilidad que fuese más moderada y modesta com sus acciones ni de menos maldades y crueldades de lo que son los japones, ni mas sujeta a razón y capaz para recibir nuestra Santa Ley". Trecho do "Libro primero del principio..." In: ibid., p. 32 nota 53.

${ }^{255}$ VALIGNANO, Alexandre, Sumario de las Cosas de Japon, In:ibid., p. 26.

${ }^{256}$ No "Vocabulario da Lingoa de Iapam com adeclaração em Portugues, feito por alguns padres $e$ irmãos da Companhia de Iesu" de 1603, a definição de 'cami' é somente "Que veneram os gentios do Japão". O verbete fotoque não foi encontrado na edição fac-símile, mas somente na edição traduzida para o japonês (邦訳日葡辞書) que, numa tradução livre, é definido como “Ídolo fortemente adorado pelos japoneses. Espírito para o qual rezam por ajuda."
} 
medieval - a religiosidade japonesa se estruturou numa dualidade ${ }^{257}$. Acreditava-se que enquanto o culto aos kami traria benefícios neste mundo (boas colheitas, existência pacífica, etc.) os Budas ${ }^{258}$ seriam entidades que guiariam o indivíduo para salvação no outro mundo. A crença em uma das entidades não excluía necessariamente a crença na outra.

Os sacerdotes budistas, por sua vez, embora extremamente criticados por Valignano, agiam de forma muito inteligente. Nas suas palavras:

Tuvieron también estes bonzos tan grande aparato en sus cosas, instituyendo tantas cerimônias y viviendo cuanto a este culto exterior con tanta modestia y limpieza y procediendo con tanto orden y madureza en sus cosas, que no es de maravilhar si alcanzaron tan grande reputación entre los japones. ${ }^{259}$

Tal afirmação embasa em grande parte a defesa de Valignano de que os padres e irmãos adotassem, no Japão, certos costumes e hábitos praticados pelos bonzos para assim se fazerem respeitados. Além de tais sacerdotes serem tidos em alta estima pela população, Valignano defendia que:

(...) están los japones tan casados con sus costumbres y cerimônias, que aunque se hunda el mundo no han de dejar ni un punto de su ordinario. Y a la verdad, proceder entre ellos de outra manera es descortesia y poca crianza. ${ }^{260}$

Desta forma, os padres poderiam e até deveriam seguir determinados costumes dos bonzos, inclusive no que toca a ritos religiosos, para que melhor se fizessem aceitos dentre os japoneses. No seu Cerimonial ele afirmara que:

Importa muito pera se conservar esta authoridade fazerem-se todos os officios da Igreja com muita reverencia e apparato exterior, sem strepto nem pressa, mas pausadamente, assi como fazem os bonzos. ${ }^{261}$

\footnotetext{
${ }^{257}$ Tal idéia é defendida por Bitō Masahide em seu artigo “Thought and Religion 1550-1700”, presente na coletânea HALL, John Whitney (ed.), op. cit., (1990).

${ }^{258}$ Hotoque significa Buda. A partir do século XV os mortos eram referidos como hotoques, o que indica que as pessoas acreditavam que os mortos entravam para o reino de Buda como resultado dos rituais religiosos performados pelo sacerdote em nome da comunidade. Ver MASAHIDE, Bitō. Thought and Religion 1550-1700. In: HALL, John Whitney (ed.), op. cit., (1990).

259 VALIGNANO, Alexandre, Sumario de las Cosas de Japon, In: TALADRIZ, J. C. Alvarez, op. cit., p. 64.

260 VALIGNANO, Alexandre, Sumario de las Cosas de Japon, In: ibid., p. 51-52.

261 Alexandre Valignano. Advertimentos e Avisos Acerca dos Costumes e Catangues do Jappão. 1583. In: SCHÜTTE S.J., Giuseppe Franz. Op. Cit. (1946), pag. 154.
} 
Valignano demonstra uma profunda sensibilidade para com o caso japonês ao notar a grande ligação da população com suas cerimônias, ainda que fossem convertidos. Desta forma procurou evidenciar, ao descrever os japoneses e seus costumes, que a única forma de evangelizá-los seria adotar alguns dos seus hábitos que, embora pareçam aos europeus estranhos ou até maléficos, não o fazer seria "descortesia y poca crianza" e só poderia resultar em um fracasso para a missão cristã.

As principais características do povo japonês, descritas por Valignano em seu Sumário, são: a preocupação que possuem com a limpeza em seu comer e vestir, a afeição que possuem desde pequenos pelas armas, a paciência e moderação que têm ao demonstrar suas paixões e a modéstia e cortesia que exprimem inclusive na sua língua tão complexa e elegante. Ao enfatizar tais características, o autor procurava convencer o leitor não apenas da complexidade e "civilidade" do povo japonês, mas também da necessidade do envio de missionários preparados intelectualmente para trabalharem na missão, algo já pedido nos primeiros anos de missão pelo primeiro superior, Cosme de Torres. ${ }^{262}$ Além disso, dava ênfase nas características que considerava serem essenciais dos japoneses para que, dessa forma, os missionários europeus pudessem se adaptar melhor às mesmas.

O caso da limpeza, repetidamente referido em suas obras, é sintomático. Bem sabemos que o padrão de higiene do europeu e do japonês do século XVI era discrepante e o Visitador logo percebeu a necessidade de adaptação para esse caso. Em seu Cerimonial afirmou que "não menos ajuda per ter auctoridade em Japão terem os Padres suas casas muy limpas, e assi no comer como em todo o mais (...)”. A rápida percepção de que aquilo que os europeus poderiam considerar apenas um "capricho", para o japonês era de suma importância, é característica da sensibilidade do Visitador para com o caso japonês.

\section{A província do Japão após a visita de Valignano}

Os dois capítulos seguintes (IV - De la division de la provincia de Japon y de las casas y colégios y iglesia que en ellas tenemos y particularmente en las partes de Shimo; V - De las casas y residencias de Bungo y de Miyako) Valignano dedicou à

\footnotetext{
${ }^{262} \mathrm{Em} 1551$ Cosme de Torres escreveu uma carta aos jesuítas de Goa pedindo para que os padres mandados ao Japão fossem, além de prudentes e pacientes, letrados, para que soubessem confundir os japoneses e tirá-los "de suas falsidades". Cosme de Torres. Carta aos jesuítas de Goa. 29 de setembro de 1551. In: MEDINA, Juan Ruiz de (ed.), Documentos del Japon 1547-1557, Roma, Institutum Historicum Societatis Iesu, 1990.
} 
descrição do estado da missão. O termo 'província' não é utilizado aqui como definidor do status da missão (que só foi alçada à categoria de província em 1611), mas em seu sentido mais amplo de 'país' ou 'reino'.

Quando Valignano escreveu seu Sumário, a missão japonesa já se encontrava dividida em três partes: Shimo, Bungo e Miyako, cada uma com seu superior. Ele preocupou-se, então em descrever cada uma das partes enumerando seus colégios, seminários e casas, além das cidades, senhorios com seus respectivos daimyō e número de cristãos. No total ele contabilizou, até a data de sua partida em 1582, um colégio, uma casa de provação, dois seminários para meninos nobres japoneses, dez residências, duzentas igrejas, oitenta e quatro membros da companhia (sendo trinta e dois sacerdotes europeus e vinte irmãos japoneses), cem dógicos ${ }^{263}$ e cento e cinquenta mil cristãos.

O maior número de cristãos (cento e quinze mil) encontrava-se na região de Shimo onde ficavam as terras de Omura ${ }^{264}$, Arima ${ }^{265}$, Amakusa ${ }^{266}$ e Hirado. Os principais portos frequentados pelos portugueses como Nagasaki e Hirado pertenciam à missão de Shimo.

O porto de Nagasaki e a povoação vizinha de Mogi foram doados por dom Bartolomeu à Companhia de Jesus, em 1580. Valignano cita rapidamente essa doação que causou certa polêmica em Roma, afirmando que a renda provinda da mesma era pequena, mas necessária pelo menos até que a missão tivesse outros fundos. A doação foi polêmica principalmente por que, segundo os termos da doação de dom Bartolomeu, os jesuítas deveriam assumir a responsabilidade de "matar e fazer a justiça necessária",267, o que era irregular, segundo as regras da Ordem. Valignano, contudo, escreveu uma carta, em 15 de agosto de 1580, ao geral Everardo Mercuriano, defendendo a doação já que somente desta forma poderiam garantir que Ryuzoji Takanobu, um daimyō gentio, invadisse Nagasaki e colocasse toda a cristandade de Shimo em perigo. Além disso, o porto poderia ser usado como um refúgio dos cristãos

\footnotetext{
${ }^{263}$ Dojoku. Segundo o "Vocabulario da Lingoa de Iapam com adeclaração em Portugues, feito por alguns padres e irmãos da Companhia de Iesu" de 1603 são: "Moços ou gente rapada que serve aos bonzos nas teras [templo budista]". Os jesuítas se apropriaram do termo para referir-se justamente aos moços que os ajudavam na pregação e no trabalho das casas e igrejas no Japão.

${ }^{264}$ Cujo senhor Omura Sumitada fora batizado dom Bartolomeu em 1563.

${ }^{265}$ Dom André, batizado em 1576, e seu filho herdeiro dom Protásio em 1580.

${ }^{266}$ Seu senhor, Amakusa Hisatane, batizado Miguel, falecera em 1582.

${ }^{267}$ Dom Bartolomeu de Omura. Carta de doação de Nagasaki e Mogi. 9 de junho de 1580. In: ELISON, George, op. cit., p. 94-95.
} 
de qualquer lugar do Japão e assegurava aos missionários um local de salvaguarda além da ajuda econômica. ${ }^{268}$

Voltando ao Sumário, Valignano defendia que nas terras de Omura deveria se construir um colégio para que os europeus que lá fossem aprendessem a língua e os costumes dos japoneses. Ele afirmou que tal resolução já fora discutida no terceiro ponto da oitava pergunta da Consulta e Resouiciones del Padre Vizitador. ${ }^{269}$

Em Arima ficava um dos colégios para meninos nobres japoneses, construído durante sua visita, em 1580. Assim que foi inaugurado, Valignano determinou pontualmente o regime do colégio: os meninos menores deveriam estudar apenas o catecismo, os medianos a ler e escrever o alfabeto romano e os maiores a escrita chinesa (utilizada no Japão). Aulas de órgãos e clavicórdio também seriam administradas. ${ }^{270}$

Já em Hirado, a cristandade sobrevivia graças aos navios de mercadores portugueses, pois seu daimyō, Matsura Takanobu, era 'gentio' e só permitia tal comunidade pelo lucro que tinha com o comércio com os portugueses.

Na parte de Bungo havia uma Casa de Provação e Colégio para europeus, construídos em Usuki em 1580, e a cristandade crescia graças à conversão de dom Francisco, mas ainda era a menor contabilizando apenas dez mil almas.

Miyako, por sua vez, contava com vinte e cinco mil cristãos divididos em quatro residências. Na cidade de Miyako mesmo havia uma, mas o número de cristãos era bastante reduzido: apenas trezentos. As outras residências localizavam-se nas cidades ao redor: Azuchiyama (local onde Nobunaga construíra sua fortaleza ${ }^{271}$ ), Tsunokuni senhorio de Justo Ukon ${ }^{272}$ - e Kawachi.

\section{A missão japonesa: a proposta de Valignano}

As propostas de Valignano para a missão no Japão, assim como todo o seu afinco em defendê-las, apesar da polêmica que algumas causaram, basearam-se em grande parte na valorização desta missão em particular, pelo Visitador. O quarto

\footnotetext{
${ }^{268}$ Alexandre Valignano. Carta ao Geral da Companhia. 15 de agosto de 1580. In: TALADRIZ, Jorge Alvares, op. cit., 71*-72*.

${ }^{269}$ VALIGNANO, Alexandre, Sumario de las Cosas de Japon, In: TALADRIZ, J. C. Alvarez, op. cit, p. 81.

${ }^{270}$ Ibid., p. 85 nota 75.

${ }^{271}$ Nobunaga doou o local para os padres construírem sua residência em 1580.

${ }^{272}$ Takayama Justo Ukon doou não apenas a residência como também uma renda considerável para sustentá-la.
} 
capítulo do Sumário - De la importancia de esta empresa y del grande provecho que se hace y esta para hacer en Japón - dedica-se a convencer o leitor de que, pelas palavras do próprio Valignano: “es esta empresa de Japón, sin duda, la más importante y provechosa de cuantas hay en estas partes de Oriente, y aun en todo lo descubierto". ${ }^{273}$ As razões dadas para tal classificação vão desde a alegação de que os japoneses são brancos, dados à razão e à polícia, até o fato de que não somente pobres e miseráveis se convertiam, mas também senhores e cavaleiros.

Por outro lado, toda a sua proposta de método de evangelização para tal povo baseava-se na ideia, tão repetida durante toda a sua obra e em diversas cartas suas, de que as qualidades, costumes e modo de proceder dos japoneses eram extremamente diferentes e contrários dos europeus. Desta forma, somente aqueles que presenciaram a missão seriam capazes de entender "lo que pasa en Japón" e, nem que se contasse por cartas ou pessoalmente, seria possível explicar tal situação para quem jamais a presenciou. Consequentemente, a direção de tal missão não deveria ser guiada pelas resoluções dos canonistas europeus.

Tal ideia servia claramente à defesa de sua proposta pois, uma vez que os costumes locais eram tão atípicos, a ponto de serem incompreensíveis para aqueles que jamais estiveram no Japão, a crítica ou mesmo a interdição de determinada diretriz por parte de uma autoridade em Roma acabava por ser invalidada.

Outro aspecto interessante a ser notado nas observações de Valignano acerca da diferença entre os costumes europeus e japoneses diz respeito à sua ênfase em tal fato para o caso específico do Japão. Lembremos que no século em questão (XVI), a expansão marítima ibérica levou os europeus a locais habitados por povos de culturas absolutamente diferentes das europeias ou mesmo das conhecidas até então. Não se pode dizer que os indígenas das Américas ou mesmo os indianos - conhecidos então por Valignano - eram menos diferentes dos europeus que os japoneses. A grande questão é saber classificar corretamente tal diferença.

Para o caso japonês, as diferenças de costumes eram comparáveis, por assim dizer. Quando Valignano afirmava que o Japão era "un mundo al revés de como corre

\footnotetext{
${ }^{273}$ VALIGNANO, Alexandre, Sumario de las Cosas de Japon, In: TALADRIZ, J. C. Alvarez, op. cit., p. 131.
} 
en Europa" ou mesmo quando Luis Fróis escreveu um tratado ${ }^{274}$ descrevendo os costumes europeus num paralelo com os japoneses mostrando o quanto são contrários, podemos pensar que tais costumes, por mais diferentes que pudessem ser, tinham uma base comum que possibilita uma comparação entre ambos. Ou, como Adriano Prosperi coloca, trata-se de uma realidade diferente, mas interpretável segundo modelos familiares. $^{275}$

Podemos pensar ainda que tais costumes, ainda que exóticos e contrários aos europeus, eram pensáveis e aceitos pelos padres e irmãos como diferenças de leis e hábitos e não como desvirtuações da natureza, como foram entendidos em diversos outros contextos, justamente por essa base comum que compartilhavam. Para Adone Agnolin:

(...) no esforço missionário que se destinava a realizar, a tentativa de uma possível convivência com uma cultura estranha, a compatibilidade com a Escritura Judaico-cristã entrecruzava-se, necessariamente, com outro sistema de compatibilidade dentro do qual, segundo o entendimento dos jesuítas, chineses e japoneses deveriam poder inserir-se partindo de sua peculiar ótica cultural. ${ }^{276}$

Além disso, Valignano chamava a atenção para uma questão bastante prática: a missão japonesa era conduzida em um território onde tanto os jesuítas quanto os comerciantes europeus não possuíam qualquer jurisdição e não tinham outra opção senão a de seguir as leis locais.

A principal proposta que o Visitador tinha para a missão japonesa era a "acomodação" aos costumes locais. Tal idéia não era uma completa novidade, como pudemos ver no capítulo anterior. Cosme de Torres, Xavier ou mesmo o padre moralista Francisco Rodrigues defendiam o quanto possível a acomodação aos costumes locais para engrandecimento da nova missão.

\footnotetext{
${ }^{274}$ FRÓIS, Luis, Europa Japão: um diálogo civilizacional no século XVI: tratado em que se contêm muito sucinta e abreviadamente algumas contradições e diferenças de costumes entre a gente de Europa e esta província de Japão (...),Lisboa: Comissão Nacional para as Comemorações dos Descobrimentos Portugueses, 1993 [1597].

${ }^{275}$ PROSPERI, Adriano. O Missionário, in: VILLARI, Rosário, O Homem Barroco, Lisboa: Editoral Peresença, 1994.

${ }^{276}$ AGNOLIN, Adone, op. cit., (2007), p. 202.
} 
Valignano, contudo, sistematizou tal regra tanto nas Resoluções tiradas das Consultas promovidas durante sua primeira visita, quanto no próprio Sumário que irá se preocupar também em explicá-las e legitimá-las.

As perguntas 17, 18 e 19 da Consulta e suas respectivas Resoluções referem-se justamente ao modo que os padres deveriam portar-se no comer, no vestir e nas cerimônias $^{277}$. O capítulo XXIII do Sumário, por sua vez, é dedicado justamente à forma como os padres deveriam portar-se na missão no Japão. ${ }^{278}$

Neste capítulo Valignano retoma as perguntas citadas da Consulta pedindo o cumprimento das suas Resoluções. Estas, por sua vez determinavam quanto ao comer que os padres e irmãos não deveriam comer em mesas altas, mas que se adaptassem tanto à forma quanto aos alimentos japoneses. Isso implicava na proibição de comer porcos e vacas, exceção feita às cidades de Nagasaki, Kuchinotsu e Bungo, onde a presença de portugueses era grande e tais hábitos já não estranhavam mais os nativos.

Quanto aos costumes e cerimônias, as Resoluções determinavam que no tratamento das casas e igrejas os padres copiassem os bonzos, assim como no modo de receber hóspedes, de escrever e falar. Valignano afirmou nestas resoluções que "por falta de esto estamos hasta ahora muy abatidos y tenidos en poca cuenta". ${ }^{279}$ Tais ordenações foram retomadas e enfatizadas no seu Cerimonial que pedia, inclusive, para que os padres imitassem os bonzos nos ofícios da Igreja.

No que se refere ao vestir as Resoluções da pergunta 19 determinavam que os membros da Companhia não deveriam usar seda (exceção feita aos dógicos filhos de nobres que tivessem menos de 16 anos), mas que usassem mantos em dias solenes ou em visitas aos senhores. Tal resolução vai bem ao encontro das Constituições da Companhia que colocam:

Quanto ao modo de vestir, três coisas se hão de ter em conta: em primeiro lugar, o traje deve ser modesto; deve em seguida ser adaptado ao país onde se vive; finalmente que

\footnotetext{
${ }^{277}$ Pergunta 17: Do modo que se há de guardar os nossos no comer em Japão; Pergunta 18: Se é bom guardar em tudo os costumes e cerimônias que os bonzos usam; Pergunta 19: Dos vestidos que devem usar os nossos. Consulta de Japón e sus Resoluciones, In: TALADRIZ, J. C. Alvarez, op. cit., p.241 a 248 nota 23.

${ }^{278}$ Capítulo XXIII - Del modo que han de guardar los Padres en Japón, así en casa como fuera.

${ }^{279}$ TALADRIZ, J. C. Alvarez, op. cit., p.245 nota 23.
} 
não esteja em contraste com a nossa profissão de pobreza, como seria se usássemos sedas ou tecidos finos. ${ }^{280}$

Além de retomar tais resoluções, o capítulo XXIII acrescenta que os padres deveriam viver "com limpeza" da forma como viviam os japoneses. As casas deveriam estar sempre limpas, principalmente quando fossem receber hóspedes e, embora estivessem desde o início do superiorato de Cabral proibidos de vestirem seda, deveriam ter suas roupas sempre limpas e bem tratadas. ${ }^{281}$

Valignano pedia ainda nesse capítulo para que os membros da Companhia cuidassem de "guardar policia en su trato, siendo muy bien criados y tratándose con cortesía, así dos de casa entre si, como los forasteros", ${ }^{282}$ para não serem tidos por mal criados e sem polícia pelos japoneses.

Além disso, os padres deveriam cuidar para não perder a sua autoridade para não ficarem em desvantagem com os bonzos que gozavam de grande autoridade dentre os japoneses. Para isso, eles precisariam estar bem informados e dispostos a acomodar-se aos costumes locais, pois, segundo o Visitador:

(...) no deben ni pueden los Padres ni aun los Hermanos ponerse a hacer por si muchas cosas de las que acostumbramos a hacer en Europa, porque pierden con eso mucho la autoridade con los japones, y los señores y caballeros lo toman muy a mal, porque tratándose los bonzos con tanta autoridad, como se tratan en todo, y no siendo capaces hasta ahora, ni aun los cristianos, de la llaneza y humildad cristiana, juzgan que es contra la autoridade de la ley y de ellos mismos tratarse bajamente los Padres, y siempre hay muchas quejas de esto. ${ }^{283}$

Pelo que expusemos até aqui, Valignano defendia a acomodação aos costumes japoneses no tocante à forma de portar-se com os nativos ${ }^{284}$ (receber visitas, guardar autoridade, ser cortês, etc.), às vestimentas - ainda que guardada a proibição do uso da

${ }^{280}$ Constituições da Companhia de Jesus, VI, cap. 2 , § 577. In: LOYOLA, Ignácio de (santo), op. cit., p. 181.

${ }^{281}$ A proibição do uso da seda foi confirmada nas Obediencias do P. Alexandre Valignano, Vizitador da Provincia de Japão e China, revistas e convertadas pello P. Francisco Passio Visitador da mesma Provincia, para instrucção dos Reytores. Anno de 1612. Tais Obediências foram válidas de 1580 a 1612. In: TALADRIZ, J. C. Alvarez, op. cit..

${ }^{282}$ VALIGNANO, Alexandre, Sumario de las Cosas de Japon, In: TALADRIZ, J. C. Alvarez, op. cit., p. 235.

${ }^{283}$ VALIGNANO, Alexandre, Sumario de las Cosas de Japon, In: ibid., p. 240.

${ }^{284}$ Em outro trecho do Sumário Valignano defende que os padres e irmãos devem tratar os japoneses "conforme a su condición y a su modo, no los queriendo llevar por las condiciones y modo de proceder de Europa". VALIGNANO, Alexandre, Sumario de las Cosas de Japon, In: ibid., p. 207. 
seda -, à alimentação e modo de comer. Tais hábitos tratavam-se apenas de práticas civis e, portanto - da mesma forma como Rodrigues justificara suas respostas em 1570 -, o Visitador acreditava que não poderiam ser impostas aos nativos, mudanças no tocante a esses costumes.

Valignano dedica também em seu Sumário um capítulo para descrever as qualidades e faculdades necessárias ao Superior Universal do Japão ${ }^{285}$. Este deveria ser extremamente capaz, pois era a missão japonesa "una de las mayores, más importantes y más dificultosas y peligrosas" que a Companhia tinha sob seu encargo e a própria Constituição dizia que os Superiores que governassem a Companhia deveriam ser mais dotados de graças quanto maior e mais difíceis fossem as empresas que tivessem nas mãos. O superior precisaria ainda ter muita experiência na terra, por ser tal província tão diferente de todas as outras, ser muito prudente ${ }^{286}$, virtuoso e estar disposto a mortificações para se acomodar aos "comeres, costumbre y naturalezas" dos japoneses e, para isso, precisaria ainda ter boa saúde e não ser nem velho nem jovem demais.

Já os sujeitos que fossem enviados ao Japão ${ }^{287}$ deveriam ser prudentes, maduros, mansos (deveriam saber controlar sua cólera já que os japoneses eram tão controlados), obedientes, aptos para aprender a língua e costumes japoneses e deveriam ter terminado seus estudos, pois o aprendizado da língua nativa tomava muito tempo.

Desta forma, tanto os Superiores quanto os Padres e irmãos deveriam estar dispostos a acomodar-se aos costumes locais a despeito de qualquer dificuldade, afinal, como o próprio Valignano coloca em seu Sumário: “por amor de Dios dejamos nuestras tierras y pasamos tantos trabajos para ir ayudar los japones, no perdamos el fruto y el trabajo por no nos querer acomodar a ellos". 288

A defesa da acomodação, por sua vez, baseava-se não somente no fato de que o modo de proceder dos japoneses eram contrários aos europeus (algo que - como já citamos acima - pode ser pensado para diversas outras missões de fora da Europa), mas também na ideia de que os japoneses eram tão civilizados e racionais quanto os europeus e, consequentemente, seriam ótimos cristãos. Além disso, os japoneses

\footnotetext{
${ }^{285}$ Capítulo XXI - De las cualidades y facultades que han de tener los Superiores de Japón.

${ }^{286}$ A prudência é um conceito central tanto para Valignano na defesa da acomodação quanto para a ordem dos jesuítas. Discutirei no quarto capítulo separadamente o uso desse conceito.

${ }^{287}$ Capítulo XXII - De los sujetos que se han de enviar a Japón y de sus cualidades.

${ }^{288}$ VALIGNANO, Alexandre, Sumario de las Cosas de Japon, In: TALADRIZ, J. C. Alvarez, op. cit., p. 201.
} 
possuíam uma disposição natural para a religiosidade. Tal característica fora notada desde o início da missão, como podemos ver nas cartas e obras de Cosme de Torres e Luis Fróis que tanto enalteciam os japoneses que se convertiam e tornavam-se bons cristãos assim como a disposição que havia em todos para se converterem. Valignano enfatizou essa disposição afirmando que havia nos japoneses uma inclinação natural para a religião, o que poderia ser comprovado pelo grande número de bonzos existentes, assim como no respeito que os nativos dedicavam aos mesmos.

Apesar dessa alta estima tida pelos japoneses, assim como a confiança na virtude religiosa dos mesmos, Valignano não deixou de admitir que tal cristandade necessitava de cuidados especiais para não se desvirtuar. Uma vez que os japoneses eram ainda jovens na fé e os jesuítas não possuíam qualquer jurisdição entre os mesmos, era preciso tomar alguns cuidados.

Um desses cuidados dizia respeito então somente aos pregadores: afinal, quem deveriam ser eles? O capítulo IX do Sumário ${ }^{289}$ dedica-se à defesa do monopólio da Companhia de Jesus para a missão do Japão. Tal questão fora discutida na segunda pergunta da Consulta e a favor da vinda de outras ordens fora alegada a falta de obreiros no Japão e o fato de as ordens já conviverem em diversas outras partes do mundo, inclusive na Europa. O Visitador, embora concordasse com tais argumentos, defendia a manutenção do monopólio basicamente para evitar dissensões entre os cristãos e missionários no Japão. A unidade da doutrina e dos métodos de evangelização era essencial para o crescimento da missão, pois, segundo ele, o principal motivo pelo qual os japoneses deixavam suas crenças e tornavam-se cristãos era pela grande contrariedade existente entre as diversas seitas budistas e xintoístas. Além disso, os jesuítas já possuíam, àquela altura, longa experiência no arquipélago e, uma vez que os costumes e modo de proceder eram tão diferentes, os missionários de outras ordens poderiam acabar agindo de forma prejudicial à propagação da fé justamente pela falta de experiência no local.

A defesa de tal unidade doutrinária ia além. Valignano não somente escolheu a dedo as obras que deveriam ser traduzidas para o japonês, mas também pediu a cautela no uso de qualquer obra, "porque ellos no tienen ni pueden tener otros libros sino los

\footnotetext{
${ }^{289}$ Capítulo IX - Como no conviene ir a Japón otras religiones.
} 
que nosotros les daremos". ${ }^{290}$ No Regimento pera os Semynarios de Japan 1580, Para nuestro $P$. General que escreveu ainda durante sua primeira visita ele pediu para que os padres evitassem ensinar aos estudantes nativos as diversidades de opinião existentes dentre os canonistas europeus, assim como as controvérsias heréticas. Em suas palavras: “deve-se apenas ensiná-los a doutrina sólida e verdadeira, de forma que saibam de filosofia e teologia somente as verdades aceitas pela Igreja". ${ }^{291}$ Dessa forma, o Visitador procurava tirar proveito do isolamento do Japão em relação aos reinos cristãos, montando ali uma cristandade modelo, sem dissensões ou controvérsias.

Todo esse cuidado, assim como o enorme peso que Valignano dava ao método que deveria ser utilizado pelos missionários na evangelização, baseavam-se em um argumento essencial para rebater as diversas críticas que seus opositores lhe fizeram: a ausência de milagres. Mesmo que a doutrina cristã fosse a única Verdade para todos, os pagãos não seriam facilmente convencidos disto pois Deus não mais se comunicava através de milagres, como o fizera na Igreja primitiva. Assim, os missionários precisariam de destreza e prudência para convencer os nativos a largarem suas crenças antigas e abraçarem o cristianismo. Em suas palavras:

(...) aunque confio en la Divina Providencia que tendrá cuidado de la Compañia y de aquella su nueva Iglesia, todavía me persuado que uno de los efectos de Su Providencia es darme esta solicitud y pena para que por todas las vias posibles y racionales procure de buscarle su remédio. ${ }^{292}$

Desta forma, os missionários não poderiam somente confiar na Providência Divina para o engrandecimento das missões, mas precisariam também utilizar de todas as vias racionais para que tivessem pleno sucesso.

\section{A CRÍTICA A VALIGNANO - A VISÃO DE CABRAL}

$\mathrm{Na}$ pesquisa sobre a querela acerca dos métodos evangelizadores para a missão japonesa envolvendo os missionários jesuítas, pode-se perceber que, de uma maneira geral, a historiografia coloca Francisco Cabral muito mais como um antagonista de Valignano, pouco analisando sua posição separadamente. O Visitador, por sua vez, em

\footnotetext{
${ }^{290}$ VALIGNANO, Alexandre, Sumario de las Cosas de Japon, In: TALADRIZ, J. C. Alvarez, op. cit., p. $144-145$.

${ }^{291}$ VALIGNANO, Alexandre, Regimento pera os Semynarios de Japan 1580, Para nuestro P. General, Apud: ELISON, G.. Deus destroyed: the image of Christianity in early modern Japan, Cambridge, 1973, p. 66, (tradução livre).

${ }^{292}$ VALIGNANO, Alexandre, Sumario de las Cosas de Japon, In: TALADRIZ, J. C. Alvarez, op. cit., p. 331.
} 
suas diversas obras e cartas, em muito contribuiu para a visão que acabou predominando de Cabral como um sujeito intransigente que pouco simpatizava com os japoneses. Contudo, ao analisar as cartas do antigo Superior do Japão - muito menos numerosas que as do Visitador - podemos entender melhor sua posição e perceber que se tratava muito mais de uma discordância de fundamentos do que uma "birra", como muitas vezes é colocado por Valignano ou pela atual historiografia.

\section{A evangelização dos japoneses na visão de Cabral}

A resistência de Cabral em montar uma estratégia missionária especificamente para o Japão não é resultado de qualquer oposição que tivesse à missão em questão, mas sim da idéia de que a solução para o processo evangelizador deveria ser encontrada dentro da Companhia e não fora dela. Desta forma, ele discordava essencialmente de Valignano que defendia que somente aqueles que tivessem trabalhado e vivido no Japão seriam capazes de dizer o que era melhor para tal missão.

Para Cabral o processo evangelizador deveria ser o mesmo, independente dos costumes ou valores locais. Este deveria ser fundado no Instituto da Companhia que pregava a humildade, a simplicidade, a pobreza e a imitação dos apóstolos e santos. Na carta que escreveu ao Geral da Companhia um ano após chegar ao Japão, Cabral enfatizou tal idéia afirmando tê-la passado aos padres e irmãos que ali trabalhavam: “(...) que confiasen na virtude da obra que ho mandava e no caminho que Christo ensinara que era de humildade e pobreza e que elle tinha os corações dos homens na mão os mudaria e faria propensos". 293

Dessa forma, a verdadeira conversão só ocorreria pelas mãos de Deus "que move os corações e hos tem em sua mão para os inclinar onde quer". ${ }^{294}$ Não por isso, Cabral acreditava que os missionários nada poderiam fazer por suas próprias mãos na obra da conversão. Em suas palavras:

(...) nem eu tenho por mao buscar meios humanos pera juntamente com hos divinos se fazer o serviço de Deos N. Senhor, todavia estes ham-de ser acommodados e conformes à mesma obra da canversam, fundados em humildade, pobresa e grande confiança em

Deos e desconfiança da propria industria, porque esta foy a bençam que ho mesmo Deos

\footnotetext{
${ }^{293}$ Francisco Cabral. Carta ao Geral da Companhia. 05 de setembro de 1571. In: CORREIA, Pedro Lages Reis, op. cit. (2007), p. 71.

${ }^{294}$ Francisco Cabral. Carta ao Geral da Companhia. 15 de dezembro de 1593. In: WICKI S.J., Joseph; GOMES S.J., John (eds.). Documenta Indica (1592-1594), v. XVI, Intitutum Historicum Societatis Iesu, Roma, Via dei Penitenzieri, 1984, p. 544.
} 
deitou aos Apostolos quando os mandou a converter o mundo (...) estas mesmas receitas deixarão elles a seus sucessores, por estas continuou a Igreja de Deos ategora. ${ }^{295}$

Assim, os missionários deveriam buscar soluções para aumentar e melhorar a comunidade de cristãos onde quer que fosse, mas sempre de acordo com o "Instituto da Companhia".

Cabral não foi insensível às peculiaridades da sociedade japonesa e prova disso foi a permissão que pediu, já em 1571, ao padre Geral para que abrisse uma exceção para que os senhores japoneses que se convertessem fossem autorizados a casar-se com gentios já que eles não se casavam com pessoas de estrato social inferior e ainda havia poucos senhores conversos. ${ }^{296}$ Tal pedido ainda fora reforçado por Valignano após a sua primeira visita, mas em 1583 a Cúria romana rejeitou os chamados "casamentos mistos" (por disparidade de cultos) ${ }^{297}$. Além disso, em carta datada de 1576, Cabral demonstrou objeção à destruição de templos budistas na região de Bungo, pois, em suas palavras "avia causa de aver algum alvoroço". ${ }^{298}$

Fica claro, portanto, que o Superior não considerava o processo de evangelização de forma que marginalizasse certas características da sociedade japonesa e mostrou inclusive a necessidade de tolerância para alguns casos, contudo, não de forma que pudesse "corromper" a forma de vida dos missionários jesuítas.

Se, por um lado, Valignano procurou entender os traços sócio-culturais japoneses para que a evangelização pudesse ser integrada em tal sociedade, Cabral, por outro, fez exatamente o contrário, buscando sempre analisar a cultura japonesa com o propósito de aproximar o mundo exterior (a sociedade na qual a missão estava inserida) à Companhia de Jesus. Tal postura refletia sua convicção na universalidade de determinados valores, como por exemplo a pobreza. Cabral percebeu que até mesmo alguns monges budistas recusavam-se a usar seda e vestiam apenas panos de algodão ou linho pretos e, em suas palavras, "nem por isso são menos venerados que os que andão

\footnotetext{
${ }^{295}$ Francisco Cabral. Carta ao Geral da Companhia. 15 de dezembro de 1593. In: ibid., p. 544.

${ }^{296}$ Francisco Cabral. Carta ao Geral da Companhia. 05 de setembro de 1571. In: CORREIA, Pedro Lages Reis, op. cit., (2007).

${ }^{297}$ RIBEIRO, Madalena Teotónio Pereira Bourbon, op. cit.

${ }^{298}$ Francisco Cabral. Carta ao Geral da Companhia. 09 de setembro de 1576. In: CORREIA, Pedro Lages Reis, op. cit., p. 57, nota 48.
} 
carregados de seda"299. Assim, mesmo entre os gentios a pobreza poderia ser entendida como um valor.

A despeito de toda a preocupação que o Visitador demonstrou na sua primeira visita ao Japão acerca do destino que a missão tomara desde o início do segundo superiorato, uma análise estatística do número de conversos revela o irrefutável sucesso de Cabral: de acordo com o padre Gaspar Vilela, em 1570 a missão japonesa contava com onze jesuítas e vinte mil cristãos, já em 1580, de acordo com o próprio Valignano, a missão contava com cinquenta e cinco jesuítas e cento e cinquenta mil cristãos. ${ }^{300}$ Cabral tinha total noção dessa situação e usou de tal alegação a seu favor em carta ao Geral Acquaviva em $1593^{301}$. Embora o antigo Superior tenha exagerado nos números (ele afirmou nesta carta que quando chegou ao Japão só havia dois mil cristãos) a rápida ascensão do número de cristãos, assim como importantes conversões de membros da elite, atestam tal sucesso.

\section{A visão do povo japonês - Cabral e Valignano}

É inegável, contudo, que Francisco Cabral nunca teve os japoneses em alta conta, como muitos dos padres que trabalharam naquela missão. Em uma carta escrita em Goa no ano de 1595, Cabral pediu ao Geral da Companhia para que não mais se aceitasse irmãos japoneses na Companhia. A principal razão alegada referia-se ao caráter pouco confiável dos japoneses. A sua descrição dos mesmos é reveladora da estima em que os tinha:

(...) não tenho visto nação mais altiva, cobiçosa e dissimulada que os japões, porque não há lavrador que em seu peyto não seja rey. ${ }^{302}$

Em outro trecho:

E chega tanto a cobiça e inconstancia delles que, ou por não perderem a renda que tem ou polla acrescentarem, os pais matão aos filhos e os filhos aos pais. ${ }^{303}$

Ou ainda:

\footnotetext{
${ }^{299}$ Francisco Cabral. Carta ao Geral da Companhia. 05 de setembro de 1571. In: ibid., p. 69.

${ }^{300}$ Ibidem.

${ }^{301}$ Francisco Cabral. Carta ao Geral da Companhia. 15 de dezembro de 1593. In: WICKI S.J., Joseph; GOMES S.J., John (eds.). Documenta Indica (1592-1594), v. XVI, Intitutum Historicum Societatis Iesu, Roma, Via dei Penitenzieri, 1984.

${ }^{302}$ Francisco Cabral. Carta ao Geral da Companhia. 29 de novembro de 1595. In: WICKI S.J., Joseph (ed.). Documenta Indica (1595-1597), v. XVII, Intitutum Historicum Societatis Iesu, Roma, Via dei Penitenzieri, 1988, p. 352.

${ }^{303}$ Francisco Cabral. Carta ao Geral da Companhia. 29 de novembro de 1595. In: ibid., p. 353.
} 
(...) tem os japões por honra e prudência não descubrirem nem ninguem lhes entender o interior, e logo de mininos os crião nisto e a serem dissimulados e fingidos. ${ }^{304}$

A visão dos japoneses como fingidos e dissimulados, entretanto, não é exclusiva de Cabral e foi compartilhada inclusive pelo próprio Valignano que no segundo capítulo do seu Sumário já chamara a atenção para os cinco principais defeitos dos japoneses sendo um deles a facilidade que tinham de mentir e fingir. Mais de quinze anos depois, numa obra escrita em Macau no ano de 1598, o Visitador afirmou:

(...) ser los japones (...) tan disimulados y recatados en descubrir lo que tienen en sus corazones que, aun después de haber conversado con ellos muchos años y tratado con mucha familiaridad a penas se puede dar buen juicio de ellos y queda mucha vezes el hombre engañado. ${ }^{305}$

Além disso, Valignano também demonstrou receio em receber um grande número de japoneses na Companhia. No sétimo capítulo do Sumário ${ }^{306}$, ele defendeu que, embora fosse necessário ter irmãos japoneses na Companhia, era arriscado aceitar um grande número deles, pois poderiam com o tempo, por estarem em terras suas, fazer o que quisessem e passariam a governar a Companhia "a su modo".

Contudo, a despeito de concordar com Cabral acerca dos pontos negativos do caráter japonês, a grande diferença na visão de ambos se encontra na raiz de tais problemas. Enquanto Cabral entendia que tais faltas eram provenientes da natureza do japonês ou, como ele afirma, "polo clima da terra e influxo das strellas", ${ }^{307}$ Valignano as explica pelo efeito de circunstâncias suscetíveis de mudança.

Ao descrever os japoneses em seus três primeiros capítulos do Sumário, Valignano afirmou que os mesmos possuíam uma boa natureza, mas que fora corrompida por diversos fatores sendo o principal as "perversas leis" instituídas pelos bonzos no passado. Em suas palavras:

\footnotetext{
${ }^{304}$ Francisco Cabral. Carta ao Geral da Companhia. 29 de novembro de 1595. In:ibid., p. 354.

305 Alexandre Valignano. Apología en la qual se responde a diversas calumnia que se escrivieron contra los P.P. de la Compañia de Japón, y de la China. Outubro de 1598. Apud: TALADRIZ, J. C. Alvarez, op. cit., p. 209 nota 16.

${ }^{306}$ Capítulo VII - De las dificuldades que hay para llevarse adelante esta empresa.

${ }^{307}$ Francisco Cabral. Carta ao Geral da Companhia. 29 de novembro de 1595. In: WICKI S.J., Joseph (ed.). Documenta Indica (1595-1597), v. XVII, Intitutum Historicum Societatis Iesu, Roma, Via dei Penitenzieri, 1988, p. 355.
} 
(...) siempre fué costumbre de gentiles vivir metidos en grandes vicios y pecados, pues de sus ídolos y maestros no pueden recibir otras leyes ni otra doctrina, y particularmente se ve esto en Japón, donde parte por las perversas leyes que el demônio y los bonzos les dieron, parte por la pobreza y continuas guerras, no es mucho verse entre ellos algunas malas cualidades, con las cuales vivieron a corromper en parte su buen natural. ${ }^{308}$

Mas mesmo assim, ele se espantara em ver como, dentre "tan perversas leyes y tantas ocasiones y libertades pudieron conservar tantas e tan buenas partes como tienen". ${ }^{309}$ Dessa forma, não somente os japoneses poderiam mudar suas características consideradas ruins pelos jesuítas como ainda possuíam disposição para isso e nada melhor do que a conversão ao cristianismo e ajuda da graça divina.

Essa diferença na visão de ambos acerca da natureza do povo japonês refletiu em outra discordância que os dois padres tiveram: acerca da função e status dos japoneses que entrassem na Companhia. Embora ambos concordassem que era necessário recebêlos, pois, nas palavras do próprio Cabral: "si no se reciben aqua mal se podra esta Christandad non digo aumentar mas ne aun sostentar por lo poco que podemos hazer sin personas que prediquen", 310 o que seguiria após tal aceitação era objeto de controvérsia.

Cabral entendia que tal integração deveria ser condicionada por uma lógica de subordinação e serviço ao clero europeu, caso contrário os japoneses - que possuiriam uma natureza desfavorecida - acabariam por promover um grande cisma e poderiam até mesmo expulsar os europeus e fazer com o cristianismo o mesmo que fizeram com o budismo séculos atrás: dividi-los em vinte e cinco seitas. ${ }^{311} \mathrm{E}$ nem mesmo uma noviciaria ou colégio para eles haveria de evitar tal resultado "assi por razão da indisposição dos sogeitos, como polo clima da terra e influxo das strellas, porque sempre parece que reyna continua desinquietação nos ânimos dos homens". ${ }^{312} \mathrm{E}$ ele ainda completa afirmando: "se a isto se ajunta fazerem-nos letrados, artistas e

\footnotetext{
${ }^{308}$ VALIGNANO, Alexandre, Sumario de las Cosas de Japon, In: TALADRIZ, J. C. Alvarez,op. cit., p. 25 .

${ }^{309}$ VALIGNANO, Alexandre, Sumario de las Cosas de Japon, In: TALADRIZ, J. C. Alvarez, op. cit., p. 25 .

${ }^{310}$ Francisco Cabral. Carta ao Geral da Companhia. 09 de setembro de 1576. In: CORREIA, Pedro Lages Reis, op. cit., (2007), p.61 nota 58.

${ }^{311}$ Francisco Cabral. Carta ao Geral da Companhia. 29 de novembro de 1595. In: WICKI S.J., Joseph (ed.). Documenta Indica (1595-1597) v. XVII, Intitutum Historicum Societatis Iesu, Roma, Via dei Penitenzieri, 1988.

${ }^{312}$ Francisco Cabral. Carta ao Geral da Companhia. 29 de novembro de 1595. In:ibid, p. 355.
} 
theólogos, como o P. Valegnano pretende, muito mais depressa há-de soceder o que disse ${ }^{313}$ E justamente por essa razão Cabral limitou os estudos dos japoneses enquanto fora Superior da missão, como conta em carta de $1576^{314}$.

Valignano, por sua vez, critica duramente tal postura afirmando que o tratamento diferenciado para europeus e japoneses só resultava em desunião entre ambas as partes e que a única estratégia capaz de atingir bons resultados a longo prazo seria fazer com que a Companhia criasse raízes no Japão dentre os nativos. O Visitador se preocupou inclusive com a forma como padres e irmãos deveriam tratar qualquer cristão converso no Japão. No Cerimonial ele pedia para que os missionários tivessem especial preocupação para fazer com que os cristãos se sintissem familiares e amados dentre os missionários, pois com isso a religião cristã ganharia crédito. ${ }^{315}$

\section{O PAPEL DA QUERELA NO CONTEXTO DA MISSÃO JAPONESA}

Como já foi colocado anteriormente o resultado imediato do antagonismo de ideias entre o Superior Francisco Cabral e o Visitador Alexandre Valignano foi a renúncia do primeiro para direção da missão no Japão. A querela entre ambos apenas se acentuou a partir de então, mas Cabral já não estava mais presente no arquipélago para fazer valer suas ideias.

Contudo, independente de tal resultado é importante atentarmos para o papel que tal disputa teve no contexto tanto das missões em geral quanto da missão japonesa, uma vez que, diferentemente dos sujeitos que vivenciaram tal momento, sabemos o desenlace final dos fatos. Afinal, a expulsão dos missionários cristãos, assim como de todo e qualquer agente proveniente dos reinos católicos europeus, invalidou toda a discussão que se ergueu acerca da maneira que a evangelização deveria ser promovida dentre os japoneses?

Após a análise de tais propostas, assim como do desenrolar da missão cristã no Japão, fica claro que tal estudo não serve somente ao propósito de compreender as diferentes missões cristãs no além mar. Como coloca Michel de Certeau: é inegável que o historiador estabelece como tarefa determinar o que um setor definido como religioso

\footnotetext{
${ }^{313}$ Francisco Cabral. Carta ao Geral da Companhia. 29 de novembro de 1595. In: ibid., p. 355.

${ }^{314}$ Francisco Cabral. Carta ao Geral da Companhia. 09 de setembro de 1576. In: CORREIA, Pedro Lages Reis, op. cit., (2007).

${ }^{315}$ Alexandre Valignano. Advertimentos e Avisos Acerca dos Costumes e Catangues do Jappão. 1583. In: SCHÜTTE S.J., Giuseppe Franz. Op. Cit. (1946), pag. 168.
} 
lhe ensina de uma sociedade como um todo ${ }^{316}$. Desta forma, a missão japonesa, assim como as discussões e disputas que se ergueram em torno dela, nos contam não somente sobre a religião cristã, mas de todo um processo de encontro que envolvem duas sociedades por inteiro (não somente aquilo que nós delineamos como 'religioso').

O historiador Jonathan Wright define bem esse papel das missões quando afirma:

As missões oferecem uma comovente lição na forma como as culturas se encontram -é preciso lembrar que é sempre uma questão recíproca, que não se pode permanecer passivo diante de um encontro, que todos os envolvidos são capazes de exploração, de rebaixamento, análises essencialistas do que parece novo e estranho, e de que todos são influenciados. ${ }^{317}$

Os missionários, por sua vez, foram os primeiros a tentar compreender a complexidade das diferenças culturais dentro de uma perspectiva de uma igualdade estrutural da humanidade. Uma vez que eles se propuseram a evangelizar diferentes povos encontrados a partir da expansão marítima ibérica, sua perspectiva não poderia ser diferente, caso contrário, como justificariam a esperança na capacidade desses povos de uma verdadeira conversão ao cristianismo? Nicola Gasbarro vai ainda mais longe ao afirmar que:

Os missionários são os primeiros antropólogos do Ocidente, não apenas pelo poder político da Igreja, mas pelo 'poder de sentido' que a religião tem no interior da modernidade nascente: eles são certamente expressão de uma instituição poderosa, mas, mais ainda, de uma cultura geral que reconhece sua autoridade simbólica e legitima o exercício desta. $^{318}$

No fim, o que os jesuítas em questão acabaram por não perceber no Japão é que, independente daquilo que eles tanto discutiram - a metodologia da evangelização, por assim dizer - o grande empecilho para a evangelização do povo japonês encontrava-se numa instituição alheia a eles: o poder central que se construía justamente nesse momento que a missão cristã se instalava no arquipélago. A sociedade que o clã

\footnotetext{
${ }^{316}$ CERTEAU, Michel de. A Escrita da História. Tradução de Maria de Lourdes Menezes. $2^{\mathrm{a}}$ edição, Rio de Janeiro: Forense Universitária, 2000.

${ }^{317}$ WRIGHT, Jonathan. God's Soldier: adventure, politics, intrigue and power: a history of the Jesuits, New York: Doubleday, 2004, p. 75. (tradução livre).

${ }^{318}$ GASBARRO, Nicola, Missões: a civilização crista em ação, In:MONTERO, Paula (org.). Deus na aldeia: missionários, índios e mediação cultural. São Paulo: Globo, 2006, p. 82.
} 
Tokugawa, assim como seus antecessores Toyotomi Hideyoshi e Oda Nobunaga, buscaram lapidar para erigir um poderoso governo não poderia permitir aquilo que a doutrina cristã tem como princípio: a igualdade essencial entre os homens. E não foram apenas os missionários jesuítas ou também os franciscanos, dominicanos e agostinianos - que chegaram posteriormente ao arquipélago - que mostraram isso ao poder central, mas também os nativos conversos que, mesmo após a ausência total de missionários europeus, continuaram sendo motivo de preocupação para as autoridades. 


\section{Cap. 4 - A tese da acomodação e o caso japonês}

\section{O EXPERIMENTALISMO DA ACOMODAÇÃO - O JAPÃO}

Ao deixar a Europa para evangelizar outros povos com diferentes culturas e desconhecidos até então, os missionários católicos, particularmente os jesuítas, não poderiam fazê-lo sem que tivessem que adaptar minimamente sua mensagem às culturas locais para que fossem compreendidos. Para o caso americano, historiadores e antropólogos falam de uma adaptação tentada através de uma "linguagem simbólica negociada" ${ }^{319}$, de uma tradução, ou simplesmente de um esforço para se fazer compreendido.

Contudo, a acomodação - proposta de evangelização da qual tratamos no capítulo anterior - não se trata simplesmente de uma adaptação. Ela vai mais longe que isso. Trata-se de uma transformação de si mesmo ${ }^{320}$. Nascida primeiramente de uma observação atenta do outro, a acomodação consiste em encontrar a porta de entrada que permite a evangelização e a incorporação da cultura alheia.

Este método foi especificamente desenvolvido e implementado para o caso asiático. Concebido concretamente para o território de missionação japonês, foi posteriormente exportado para a China por Matteo Ricci e dali para a missão indiana, cada local comportando as suas especificidades. Para Inês Zupanov, tal método:

\footnotetext{
"se assentava no conhecimento da estrutura espiritual das culturas encontradas na Ásia, tidas como 'pagãs' mas encaradas como sociedades complexas e 'civilizadas', a fim de enxertar o cristianismo por via de uma substituição ou redefinição dos costumes 'sociais' existentes.", 321
}

Contudo, até a chegada do padre Visitador Alexandre Valignano, não havia uma definição clara do método a ser seguido. Os primeiros superiores da missão, Cosme de Torres e Francisco Cabral, não foram capazes de estabelecer um modelo definitivo de ação. Assim, foi somente com Valignano que a 'acomodação' ganhou um status

\footnotetext{
${ }^{319}$ POMPA, Maria Cristina. Op. cit., p. 24.

${ }^{320}$ CASTELNAU, Charlotte. Acomodação aos bárbaros: os jesuítas e os índios tupinambás no Brasil. (cópia gentilmente cedida pela autora).

321 ZUPANOV, Ines G. História da Expansão Portuguesa, acessível no site http://www.ineszupanov.com. Acesso em: 20 jun. 10, p. 52.
} 
definido para ser implementado e seguido por todos os jesuítas que trabalhassem na missão japonesa.

Não que movimentos anteriores em sua direção não tivessem sido feitos. Isabel Pina afirma que assim que Francisco Xavier chegou ao Japão, “percebeu a lacuna do tradicional método de tabua rasa, baseado num padrão de europeização, que fora até então utilizado pela grande maioria dos missionários, inclusive pelo próprio Xavier", 322 Quando foi pela primeira vez a Miyako, a capital japonesa, Xavier intencionava falar com o imperador. Mesmo que isso fosse praticamente impossível para um estrangeiro, o fato de ele ter ido pobremente vestido e sem carregar qualquer presente agravou sua situação. E Xavier percebeu isso. No ano seguinte, quando foi visitar o daimyō de Yamaguchi, apresentou-se melhor vestido, agora na condição de embaixador do vice-rei do Estado da Índia, levando consigo sofisticados presentes como um relógio, um par de óculos, dois telescópios, um rifle, cristais e tecidos da Índia e de Portugal ${ }^{323}$. Xavier mudou assim sua imagem de forma a se adaptar à sensibilidade japonesa. O resultado foi imediato: o daimyō autorizou a pregação em seu território.

Cosme de Torres também procurou se acomodar ao estilo de vida japonês, como foi referido no segundo capítulo. Ao pedir para que se "considerem pois, os que se houverem de preparar para vir a estas partes, que princípios se têm postos em esta terra" ${ }^{, 24}$, ele demonstra sentir necessidade de se pensar ao menos uma acomodação mínima aos costumes locais.

As perguntas enviadas para a Índia e respondidas por Francisco Rodrigues em 1570 são uma evidência de que, embora os jesuítas do Japão não estivessem completamente certos acerca da melhor atitude a ser tomada, havia um esforço por parte deles para a acomodação (lembrando que Cosme de Torres estava no comando da missão no período em que as perguntas foram formuladas e enviadas).

Uma pergunta que chama bastante a atenção e é ilustrativa deste caso é a quadragésima: acerca da legitimidade do suicídio por parte dos guerreiros quando estão encurralados pelos inimigos ou quando o senhor vos ordena, para evitar desonra à

\footnotetext{
322 PINA, Isabel. Op. cit., p. 60.

323 Ibidem, p. 60.

${ }^{324}$ Cosme de Torres. Carta aos jesuítas de Goa. 29 de setembro de 1551. In: MEDINA, Juan Ruiz de (ed.), Documentos del Japon 1547-1557, Roma, Institutum Historicum Societatis Iesu, 1995,p. 210.
} 
família $^{325}$. Rodrigues não surpreendeu em sua resposta eafirmou categoricamente que tal atitude não poderia ser tolerada. Ao proibir o seppuku ${ }^{326}$, ele ignorou o código de honra existente entre a classe militar japonesa e procurou impor o mandamento cristão que proibia o suicídio. No entanto, o simples fato de os missionários terem formulado essa questão demonstra tanto uma compreensão dos valores de honra em questão quanto um esforço de acomodação para com os mesmos.

\section{ACOMODAÇÃO - IMPLICAÇÕES E NECESSIDADES}

Ao perceber que o método da tabula rasa não funcionaria para o caso japonês, Xavier e seus sucessores passaram a compreender também que a conversão não poderia ser praticada como uma total ruptura com o passado dos conversos, do seu 'mundo social'. Para uma situação em que os missionários não possuíam qualquer poder coercivo, o cristianismo precisava ser mostrado como algo atrativo.

É neste sentido que Adriano Prosperi afirma que "antes de pregar o Evangelho e pensar nas conversões, tinha de se conquistar um lugar na sociedade, ser-se aceite" ${ }^{327} \mathrm{E}$ para isso eles precisavam num primeiro momento observar atentamente os costumes e hábitos desta sociedade e a partir daí acomodarem-se a esta, pois só assim seriam aceitos.

A acomodação jesuítica apresenta-se, portanto, como uma estratégia pragmática e deve ser interpretada como parte do quadro de dificuldades enfrentadas pelos missionários que trabalharam nas missões em questão. Pode ser entendida, por um lado, como uma dissimulação, um recurso para "ganhar o jogo",328. Para as historiadoras Ana Fernandes Pinto e Silvana Remédio Pires:

(...) à luz de seus objetivos finais - efetividade - a acomodação cultural não representa uma genuína e definitiva atitude permissiva, nem deve ser confundida com uma atitude de tolerância, ao menos no sentido que tolerância é entendida hoje. A tolerância de um homem do século XVI não deve ser comparada a valores contemporâneos como liberdade de consciência ou religiosa. Além do mais, em determinados casos, tal

\footnotetext{
${ }^{325}$ Francisco Rodrigues. Resposta que alguns padres de Japão mandaram perguntar. 1570. In: PINTO, Ana Fernandes e PIRES, Silvana Remédio, op. cit.

${ }^{326}$ Forma de suicídio ritual da classe guerreira japonesa.

${ }^{327}$ PROSPERI, Adriano, O Missionário, In: VILLARI, Rosário (org.). op. cit., p. 159.

${ }^{328}$ Ibdem, p. 157.
} 
acomodação era apresentada como uma atitude temporária, a ser revogada quando a missão se consolidasse. ${ }^{329}$

As autoras aqui ressaltam o caráter pragmático do método. No caso japonês prevaleceu, desde os anos iniciais da missão, a preocupação em não colocar em perigo a conformidade social em favor de um maior número de conversões, ou ao menos de uma esperança de um maior número de conversões. Tanto Francisco Rodrigues quanto Alexandre Valignano demonstraram um cuidado específico ao tratar da introdução de certos costumes que poderiam ser estranhos aos nativos. A "atitude temporária" para alguns casos, as quais as autoras fazem menção, era parte substancial da acomodação. Poderíamos citar diversos exemplos, inclusive já mencionados anteriormente, mas, a fim de evitar repetições coloquemos aqui uma passagem do Cerimonial de Valignano que explicita de forma bem clara aquilo que as autoras propuseram e aqui corroboramos:

Ainda que reduzir os Christãos a que se confessem e tomem o Sancto Sacramento do Altar hé o proprio meo pera os fazer verdadeiros Christãos, todavia, como estes Christãos são novos e que de novo se vão cada dia fazendo, não convém correr de preça com elles com estes meios, porque primeiro hé necesario y-llos dispondo com o tempo a se fazerem capazes de receber estes sacramentos, porque, como elles viverão tanto tempo com hábitos e costumes tão depravados e tenhão tanta ignorância e falta de doutrina acerca das cousas de Deus, hé necesario primeiro faze-llos amorosos e familiares, pera que desta maneira pouco e pouco tomem gosto e vão entendendo as cousas de Deus, porque desta maneira se vão fazendo capazes, pera depois com proveito usar dos sacramentos. ${ }^{330}$

$\mathrm{O}$ fato de que naquele momento eles estavam vivendo um primeiro encontro entre japoneses e europeus - está na base de tal proposta. $\mathrm{O}$ estranhamento advindo de tal situação é tratado com naturalidade por Valignano que justifica sua proposta de forma clara e racional, montando um passo a passo da evangelização de maneira bastante lógica.

É claro que tal método implicava em riscos. Isso porque, no processo de acomodação, como coloca Adone Agnolin, “o próprio cristianismo devia (...) se

\footnotetext{
${ }^{329}$ PINTO, Ana Fernandes e PIRES, Silvana Remédio. Op. cit., p. 21. (tradução minha)

${ }^{330}$ Alexandre Valignano. Advertimentos e Avisos Acerca dos Costumes e Catangues do Jappão. 1583. In: SCHÜTTE S.J., Giuseppe Franz. Op. Cit. (1946), pag. 168.
} 
submeter a um ritual de transformação que pudesse tornar aceitável a peculiar novidade da mensagem cristã dentro de uma visão cultural tão refinada e complexa". ${ }^{331}$ Partindo desta ótica, não teria como permanecer ancorado numa rígida ortodoxia, o que poderia, por um lado, ser mais fácil. O discurso deveria ser modificado sempre com o cuidado de não extravasar certos limites. O que estava em questão naquele momento era a evangelização do povo japonês e isso jamais foi perdido de vista, quer por Cabral quer por Valignano.

Fica claro, portanto, que a ação evangelizadora teve que se propor com muito mais cuidado para não correr o risco evidente de trair e extraviar a própria mensagem ${ }^{332}$. Para o caso japonês, contudo, Valignano estava certo de que a maior dificuldade encontrava-se não na transmissão da doutrina católica, mas em questões de ordem formal e de relacionamento social. ${ }^{333}$ Embora os missionários tenham relatado alguma dificuldade ao transmitir os dogmas cristãos aos japoneses ${ }^{334}$ isso não foi impeditivo no processo de conversão em geral. Para o caso chinês, a acomodação precisou ir bem mais a fundo, como conta Isabel Pina, que fez um estudo comparativo entre as duas missões. Para ela, a acomodação praticada no Japão "foi mais superficial e assumiu um aspecto fundamentalmente social e religioso. Não foi considerada necessária uma abordagem teológica mais profunda, como foi experimentado na China". ${ }^{335}$

A acomodação japonesa buscou principalmente arranjos nos costumes civis. Como vimos anteriormente no documento redigido por Francisco Rodrigues, ele justificava algumas das suas "concessões" por determinados hábitos provirem do direito positivo e não do direito divino. Valignano seguiu pelo mesmo caminho. As modificações propostas no comportamento dos missionários, assim como as "concessões" feitas aos neófitos, diziam respeito ao universo civil da sociedade japonesa de então. Valignano não propôs qualquer mudança teológica ou doutrinária, como pudemos constatar no capítulo anterior.

\footnotetext{
331 AGNOLIN, Adone, op. cit., (2007), p. 192.

${ }^{332}$ AGNOLIN, Adone, op. cit., (2009), p. 212.

${ }^{333}$ RADULET, Carmen M., op. cit.

${ }^{334}$ Em carta de Cosme de Torres de 1551 e em outra de Luis Fróis de 1556, ambos relatam que os japoneses, leigos e bonzos, faziam perguntas "mui dificultosas" aos padres acerca da doutrina cristã. Cosme de Torres. Carta aos jesuítas de Goa. 29 de setembro de 1551. E Luis Fróis. Carta aos jesuítas de Goa. 07 de Janeiro de 1556. In: MEDINA, Juan Ruiz de (ed.), op. cit. (1990).

${ }^{335}$ PINA, Isabel, op. cit., p. 71. (tradução minha)
} 
A Companhia de Jesus, por sua vez, não propunha soluções universais para a evangelização. A ordem foi capaz de desenvolver uma análise perspicaz das particularidades de cada caso. E isso está expresso nas Constituições da Ordem. No prólogo escrito em 1559 pelo padre Pedro Ribadaneira, ele fala da dificuldade que Loyola teve ao escrever as Constituições, dada a diversidade dos costumes das diversas regiões e que "nem tudo seria conveniente para todos". ${ }^{336} \mathrm{O}$ desdobramento disso é o que ficou conhecido como "método jesuíta de acomodação cultural".

A solução encontrada obviamente não evitou polêmicas. Tais proposições prepararam a separação do social e do religioso produzindo uma infinidade de controvérsias internas ${ }^{337}$ que foram além dos limites das discussões acerca da evangelização dos povos recém encontrados. Além disso, abriu uma brecha para uma “nova dimensão política do religioso". ${ }^{338}$ Já em 1585, o Geral da ordem, Claudio Acquaviva escreveu à Valignano demonstrando certa perplexidade frente a determinados assuntos apresentados pelo Visitador na sua primeira visita ao Japão. Em sua opinião, a acomodação não visaria somente os hábitos de vida, mas também uma emulação de um determinado cerimonial religioso através de uma adaptação demasiado profunda da hierarquia da missão ao modelo Zen. Embora o princípio tenha continuado o mesmo, Valignano teve que revisar suas ordens na segunda visita que fez ao Japão (de 1590 a 1592). ${ }^{339}$

A atitude do Geral evidencia que a separação proposta por Valignano (talvez possamos citar aqui também o padre moralista Francisco Rodrigues) entre forma externo - e conteúdo - interno - não poderia ser bem delimitada. Afinal, onde exatamente acabaria a aceitação da forma e começaria a concessão aos conteúdos?

\section{AS PRÉVIAS E GUIAS DA ACOMODAÇ̃̃O}

Como já foi referido anteriormente, a acomodação aqui discutida provém da própria orientação jesuíta. Embora Valignano seja colocado como o "arquiteto" da acomodação, ele não a sistematizou sem que uma boa base estivesse formada previamente. Como já foi colocado, tanto Xavier quanto Torres demonstraram um

\footnotetext{
${ }^{336}$ Pedro Ribadaneira. Prefácio à primeira edição das Constituições da Companhia de Jesus. 1559. In: LOYOLA, Inacio de, op. cit, p. 20.

${ }^{337}$ ZUPANOV, Ines. One Civility but Multiple Religions, Paris, Research Fellow, CNRS, 2003.

338 AGNOLIN, Adone, Religião e Política nos Ritos do Malabar (século XVII): interpretações diferenciadas da missionação jesuítica na Índia e no Oriente. Clio - série de revista de pesquisa histórica, S.I., Número 27-1, 2009, p. 234.

${ }^{339}$ RADULET, Carmen, op. cit., p. 66.
} 
esforço em favor de uma adaptação aos japoneses. Mas essa brecha já havia sido aberta pelo próprio fundador da ordem, Ignácio de Loyola, que falava em "entrar pela porta deles para se sair pela nossa". ${ }^{340}$ Loyola, por sua vez, baseou-se nas Escrituras para formular tal frase. A adaptação aos interlocutores para conduzir a Cristo está presente na carta de São Paulo aos Coríntios. O próprio Catecismo Tridentino faz citação desse trecho. $^{341}$

A acomodação não era, contudo, um processo indiscriminado de aceitação e imitação das características dos povos em processo de evangelização. Ela precisaria ser bem dirigida e os melhores guias para a mesma eram, não por acaso, as duas virtudes fundamentais da formação jesuítica: a obediência e a prudência.

A obediência jesuítica era bastante rigorosa. Nas suas Constituições está colocado que os membros devem "deixar-se guiar e dirigir pela divina Providência, por meio do Superior como se fossem um cadáver que se deixa levar para onde for, e tratar à vontade". 342

Ela possui três níveis: a obediência do ato - que consistia em cumprir a ordem dada; a obediência da vontade - na qual o individual deveria cumprir a ordem como fosse deliberação da sua própria vontade; e por fim a obediência da inteligência - que seria o aniquilamento da vontade e inteligência próprias em favor de uma sintonia perfeita $^{343}$.

Contudo, a Companhia tinha total noção que nenhum trabalho catequético seria bem realizado somente na base da obediência e disciplina de ferro. Para Eisenberg:

A obediência cega pregada nos Exercícios Espirituais era de pouca utilidade no contexto de rápido desenvolvimento institucional no qual a ordem se via inserida já em 1553 . O fervor missionário dos irmãos da ordem - estivessem eles no Oriente, na América ou dispersos pela Europa - dependia de sua crença na virtude de suas próprias decisões e

\footnotetext{
${ }^{340}$ Apud. O’MALLEY, John W., op. cit.

${ }^{341}$ AGNOLIN, Adone, op. cit., (2001), p. 51.

${ }^{342}$ Constituições da Companhia de Jesus, VII, cap. 6, §547. In:LOYOLA, Ignácio de (santo), op. cit., p. 174.

${ }^{343}$ COSTA, Célio Juvenal. A Racionalidade Jesuítica: civilização e organização. In: VII SIMPÓSIO INTERNACIONAL PROCESSO CIVILIZADOR, Piracicaba, 2003. Disponível em: http://www.uel.br/grupoestudo/processoscivilizadores/portugues/sitesanais/anais7/Trabalhos/xA\%20racionalidade\%20jesuitica\% 20-\%20civilizacao\%20e\%20organizacao.pdf (acesso em 15/10/2011).
} 
da aceitação dos comandos de seus superiores, como se esses fossem o produto de sua própria deliberação. ${ }^{344}$

Nas mais diferentes missões, os padres e irmãos enfrentaram situações jamais imaginadas até então. Muitas delas foram polêmicas, como vimos até aqui, e não produziam um consenso nem mesmo dentre os membros da Ordem. Tais situações pediam respostas não formuladas nas Constituições ou em qualquer outro documento regrador da Companhia. O próprio padre Polanco afirmara que havia perguntas que "porque aca no se sabe lo particular no puede responder". ${ }^{345}$ Assim, deixava-se as respostas para o discernimento e prudência dos missionários.

Daí chegamos ao segundo guia da acomodação: a prudência. Aqui, a longa e sólida formação moral do jesuíta mostrava-se essencial. Isso porque a prudência não significava precaução, mas, muito mais complexo do que isso, significava "julgamento são". 346

A primeira advertência que Cosme de Torres fez ao advogar pela acomodação aos japoneses, ainda nos primeiros anos de sua estadia, foi justamente:

Hão de ser os padres mui prudentes pera se saber acomodar com a gente da terra, a qual cousa hé mui difficultosa. Porque às vezes hé necessário mostrar exteriormente grande severidade e às vezes pôr-sse debaixo de seus pées. E para conhecer isto hé necessário gram prudência. ${ }^{347}$

O fato de que uma viagem padrão de Lisboa a Nagasaki durava de dois anos a dois anos e meio e o retorno se estendia por mais vinte e dois a vinte e três meses ${ }^{348}$, exponenciava a importância que a decisão do jesuíta missionário tinha.

Valignano, na sua proposta de acomodação para o Japão, esteve sempre oscilando entre a obediência e a prudência. Como vimos anteriormente, ele foi obrigado a revisar algumas das suas deliberações na segunda visita que fez ao Japão, como lhe fora pedido pelo padre Geral da ordem, Acquaviva. Ao mesmo tempo, também apelou

\footnotetext{
${ }^{344}$ EISENBERG, José. Op. cit, p. 37.

${ }^{345}$ POLANCO apud LONDOÑO, Fernando Torres. Op. cit., p. 28.

${ }^{346}$ O’MALLEY, John W., op. cit., p. 131.

${ }^{347}$ Cosme de Torres. Carta ao jesuítas de Goa. 29 de setembro de 1551. . In: MEDINA, Juan Ruiz de (ed.), op. cit., (1990), p. 217. (grifo meu).

${ }^{348}$ CURVELO, Alexandra. A Arte Namban no contexto dos impérios ibéricos. In: SIMPÓSIO INTERNACIONAL NOVOS MUNDOS - PORTUGAL E A ÉPOCA DOS DESCOBRIMENTOS. 23 a 25 de novembro de 2006. Berlim. Disponível em: <HTTP://www.dhm.de/ausstellungen/veuewelten/pt/docs/alexandra_curvelo.pdf $>$ (acesso em 01/12/11).
} 
para a obediência quando escreveu os diversos regramentos a serem seguidos pelos missionários em atividade no Japão.

\section{A PRUDÊNCIA PARA A ACOMODAÇÃO NO JAPÃO}

A prudência desempenhou papel primordial, mais do que a obediência, para o caso do método da acomodação. No papel de mais alta autoridade da Companhia nas Índias Orientais, Valignano delineou as regras para a acomodação no Japão, mesmo que à revelia de alguns importantes membros da ordem ${ }^{349}$. Para Taladriz:

A definição aristotélica de prudência (...); a insistência tomista na qual a prudência de modo algum tem uma só cara especulativa (...), e primordialmente a doutrina paulina da cristianização dando primeiro leite que pão duro (...) são pedras angulares de seu [Valignano] método missionário. ${ }^{350}$

A aplicação do seu método para o Japão, muito embora não tenha impedido a falência da missão, teve efeitos práticos consideráveis e a ordenação, em 1601, dos dois primeiros padres japoneses ${ }^{351}$ é apenas um dos diversos exemplos das consequências dessa política.

Valignano soube eleger bem as características da sociedade japonesa a serem copiadas pelos missionários demonstrando uma total noção do jogo de poderes que a Companhia precisaria entrar para se fazer aceita no Japão. Exemplo disso foi sua proposta para que os missionários imitassem os bonzos em alguns de seus costumes e cerimônias. Os bonzos a ser copiados, entretanto, deveriam ser preferencialmente os da seita zen.

O zen-budismo fora introduzido no Japão apenas no século XII, no período Kamakura, por Myōan Eisai ${ }^{352}$ (1141-1215), num movimento de renovação do universo budista japonês, graças à introdução de novas seitas que conjuntamente ficaram conhecidas como Novo Budismo ou Budismo Kamakura (em referência à época que foram introduzidas).

\footnotetext{
${ }^{349}$ Francisco Cabral é apenas um dos exemplos de antagonistas das idéias de Valignano. Posteriormente, quem combateu fervorosamente suas idéias para a província do Japão foi João Rodrigues Tsuzu (o intérprete). Na província da Índia Jerônimo Xavier, Francisco Vieira e Manuel de Lis eram contra seus métodos. Ver: WICKI S.J., Joseph. Introdução. In: WICKI S.J., Joseph; GOMES S.J., John (eds.). Documenta Indica (1592-1594), v. XVI, Roma, Intitutum Historicum Societatis Iesu, 1984.

${ }^{350}$ TALADRIZ, J. C. Alvarez, op. cit., p. $10^{*}$.

351 ZUPANOV, Ines G. História da Expansão Portuguesa, acessível no site http://www.ineszupanov.com. Acesso em: 20 jun. 10.

${ }^{352}$ Também conhecido como Yōsai.
} 
Zen é a palavra japonesa originada do vocábulo chinês Ch'an, que quer dizer estado meditativo profundo. O primeiro monastério zen-budista no Japão foi fundado por Eisai, em 1195, (o Shōfukuji, em Hakata) graças ao então xogum Minamoto Yoritomo que, a despeito de todo o antagonismo que a seita rinzai ${ }^{353}$ sofreu pelas seitas do antigo budismo ${ }^{354}$ intercedeu pela construção do monastério ${ }^{355}$.

Essa intervenção de Yoritomo a seu favor logo ligou o zen-budismo ao Bakufu. Os discípulos de Eisai formalizaram alianças com o clã Hōjō, regentes do período Kamakura, após a morte de Yoritomo.

A institucionalização do zen-budismo foi completada no Muromachi, com a implantação do modelo de origem chinesa Gozan (cinco montanhas), o qual inseria os monastérios zen mais notórios numa rede de classificação organizada pelo Bakufu. Mesmo alguns monastérios do zen-budismo Sōtō - introduzido por Dōgen (1200-1253) pouco depois de Eisai ter trazido o Rinzai - que não se ligara ao poder central inicialmente, entraram no modelo Gozan, ainda que em número bastante reduzido.

O zen-budismo teve uma grande e rápida aceitação, principalmente entre a classe guerreira (buke). Tal aceitação deve-se tanto por uma identificação desta para com seus ensinamentos ${ }^{356}$ quanto por questões mais pragmáticas. Primeiramente, o budismo esotérico das seitas shingon e tendai era bastante ligado à aristocracia imperial (kuge) e a interferência nessa relação era politicamente complicada. Em segundo lugar, o caráter fortemente monástico do zen impedia, em grande parte, a participação de seus membros em movimentos contestatórios. Por fim, a classe guerreira, embora carregasse o poder de facto no Japão, ainda era vista como culturalmente inferior à aristocracia imperial. O rico aparato artístico e literário do zen, assim como sua forte ligação com a

\footnotetext{
${ }^{353}$ Rinzai é um dos ramos do zen-budismo no Japão.

${ }^{354}$ Seitas budistas introduzidas anteriormente à Kamakura. A maioria foi introduzida no período Heian (794-1185).

${ }^{355}$ FUTIDA, Cristina Ayumi. Institucionalização das Seitas Rinzai e Sōtō Zen no Japão dos Períodos Kamakura e Muromachi. Dissertação (mestrado em Letras) - departamento de Letras Orientais da Faculdade de Filosofia, Letras e Ciências humanas da Universidade de São Paulo, São Paulo, 2001.

${ }^{356}$ A efemeridade da vida é um dos temas centrais do zen-budismo. Diferente das antigas seitas budistas o zen cultiva a plena atenção no aqui e agora. Dessa forma, a classe guerreira, para a qual a morte é um perigo constante, acabou por se identificar com o modo com que a seita lida com a questão existencial. Ver: FUTIDA, Cristina Ayumi. Op. cit., p. 46.
} 
cultura chinesa ${ }^{357}$, podem, portanto, ter atraído os bushi descontentes com tal inferiorização. ${ }^{358}$

Valignano provavelmente não sabia de toda a história da introdução e institucionalização do zen, mas percebeu logo a ligação da classe guerreira, detentora do poder de facto, com a seita. Ciente da impossibilidade e inoperatividade de uma ligação com os kuge, ele buscou justamente a imitação dos bonzos respeitados pelos buke. Em seu Cerimonial ele é bem claro quando discute em seu primeiro capítulo o modo "para adquirir e conservar autoridade" entre os japoneses ${ }^{359}$ :

Pera isto parece que aos Padres e Irmãos, que são os bonzos da religião Christã, pelo menos convém por-se na mesma altura em que estão os bonzos da seyta dos Genxus ${ }^{360}$ que entre todas hé tida em Japão por principal e que tem mais commonicação com toda a sorte de gente de Japão.

Nesta passagem, Valignano é bem claro e direto na sua proposta: os missionários devem se colocar à mesma altura que os bonzos mais respeitados e articulados do Japão. Ele não afirma que tais bonzos sejam os melhores em questões morais ou por qualquer coisa do tipo. O pragmatismo aqui é óbvio para o leitor e serve claramente como um argumento plausível dentro da linha de pensamento do Visitador.

Por outro lado, os monges da seita $J \bar{o} \bar{o}$, Terra Pura, a seita mais popular no Japão do século XVI, também não foram especialmente valorizados pelo visitador. $\mathrm{O}$ fato de que alguns deles faziam trabalhos dentre os pobres e doentes não foi citado por Valignano que, mesmo que tivesse notado tais atitudes, não advogaria pela imitação das mesmas ou de seus bonzos, uma vez que estes dirigiam suas atividades principalmente às camadas populares e não às elites.

Nas suas Resoluciones das três consultas feitas na sua primeira visita, Valignano chamou a atenção para a necessidade do cuidado com a limpeza e modos nas refeições. Na resposta à pergunta 17 - dedicada exclusivamente ao modo que os padres e irmãos deveriam ter ao comer - ele colocou que os japoneses eram:

\footnotetext{
${ }^{357}$ Tanto Dōgen quanto Eisai estudaram na China antes de difundirem o Rinzai e o Sōtō Zen no Japão. ${ }^{358}$ FUTIDA, Cristina Ayumi. Op. cit.

${ }^{359}$ Cap 1: Do modo que se há de ter pera adquirir e conservar authoridade tratando com os jappoens.

${ }^{360}$ Genxus: referência a sei Zen (shu em japonês significa seita).
} 
“tan limpios en su manera de comer, viendo la suciedad de nuestros refectorios y cocinas, la manera de nuestro comer con tanta gordura, tan extrañada al gusto y a los ojos de ellos, y viendo la poca limpieza que teníamos en nuestras cosas, en la cual los japones, especialmente los bonzos todos, tanto se esmeran, quedamos con ellos tenidos por gente sucia y de poca estima". ${ }^{361}$

Como o próprio visitador colocou, os japoneses em geral, mas principalmente os bonzos, os viam como "sujos" em seus hábitos alimentícios. Os bonzos da seita zen, por sua vez, valorizavam especialmente a higiene pessoal e a etiqueta usada durante as refeições. Em sua obra, Dōgen afirmara que tais hábitos eram essenciais e que faziam parte de um ritual de purificação ${ }^{362}$.

Valignano percebera a importância dada à higiene e à etiqueta pelos bonzos. Ele chegou a afirmar até mesmo que "en la madurez y en el trato de sus [dos bonzos] casas e personas, nos hacen tan gran ventaja que yo mismo me espanto cuando la considero". 363

\section{A FALÊNCIA DA ACOMODAÇÃO PARA O JAPÃO}

George Elison, em seu livro "Deus Destroyed" faz um comentário bastante pertinente a respeito do fim do cristianismo no Japão. Em suas palavras:

"Os heróis cristãos trabalharam para tapar buracos em uma estrutura que jamais fora sólida. Homens como Cabral só podem ser condenados por uma negligência que tornou o processo de dissolução mais rápido e fácil. Hideyoshi e os Tokugawa perseguiram o cristianismo por este ser uma força externa que acabara por se engajar nas intrigas políticas (...). O cristianismo entrou no jogo político justamente porque a patronagem política era a base de sua existência no Japão.”364

Assim, independente da operatividade do método da acomodação para o Japão, o cristianismo não conseguiu sobreviver ao jogo político das elites japonesas do início da modernidade. Não por qualquer ineficácia dos métodos de evangelização propostos (podemos incluir aí também aquele advogado por Cabral), mas justamente por uma inadequação ao jogo político.

\footnotetext{
${ }^{361}$ Consulta de Japón e sus Resoluciones, In: TALADRIZ, J. C. Alvarez, op. cit., p. 241 a 248 nota 23. ${ }^{362}$ FUTIDA, Cristina Ayumi. Op. cit., p. 29.

${ }^{363}$ Consulta de Japón e sus Resoluciones, In: TALADRIZ, J. C. Alvarez, op. cit., p. 241 a 248 nota 23.

${ }^{364}$ ELISON, George. Op. cit., p. 85. (tradução minha).
} 
O budismo, por sua vez, também um exemplo da ingerência de uma cultura estrangeira, ainda que muito anterior ao cristianismo no Japão, nunca deixou de ser uma preocupação para as autoridades japonesas. Para além de sua origem, tal preocupação se ancora também no fato de que no Japão o budismo não era relegado a um domínio isento de questões temporais, mas era visto como razão para a política de Estado e existência de instituições governamentais. Muitos dos debates sectários budistas foram inspirados em questões políticas ${ }^{365}$. Assim, podia ser tanto uma doutrina perigosa quanto favorável ao poder.

Com a introdução das novas seitas budistas em Kamakura, o budismo passou, a partir de então, a ser difundido para todos, não mais apenas às elites ${ }^{366}$. Desta forma, o período compreendido entre os séculos XIV e XVI viu o estabelecimento de uma instituição religiosa comum ao país. A difusão de um padrão comum de práticas religiosas, tanto geográfica quanto socialmente, pode ser vista como evidência da formação de uma "religião nacional". 367

Por outro lado, o xintoísmo, religião considerada nativa, presente na prática de adoração aos kami, era bastante difundido dentre a população japonesa há muitos séculos. Mesmo após a introdução das seitas de Kamakura, que se opunham a um sincretismo com tais práticas, não deixou de ter uma importante influência no cotidiano e pensamento dos japoneses pré-modernos e modernos. A fé simultânea nos kamis como protetores da vida cotidiana e nos Budas como entidades que guiariam o indivíduo para a salvação num outro mundo, levou à formação de uma religiosidade estruturada mais numa dualidade que num sincretismo ${ }^{368}$, como já foi colocado no segundo capítulo da presente dissertação.

Os embates de Oda Nobunaga contra instituições budistas no processo de reunificação são exemplos importantes para entender as políticas do Estado japonês em formação em relação a movimentos e organizações religiosas. Chave também, portanto, para entender as diferentes atitudes perante o cristianismo.

\footnotetext{
${ }^{365}$ WELTER, Albert. Zen Buddhism as the Ideology of the Japanese State: Eisai and the Közen Gokokuron, In: HEINE, Steven e WRIGHT, Dale S. Zen Classics - Formative texts in the History of Zen Buddhism, Oxford University Press, 2006.

${ }^{366}$ As seitas anteriores à Kamakura eram orientadas primordialmente para a aristocracia. Ver: MASAHIDE, Bitō. Thought and Religion 1550-1700, In: HALL, John W. (ed.), op, cit. (1991).

${ }^{367}$ Termo utilizado por Bitō Masahide em seu artigo MASAHIDE, Bitō. Thought and Religion 15501700, In: HALL, John W. (ed.), op, cit. (1991).

${ }^{368}$ Ibdem.
} 
É importante ressaltar, contudo, que tais embates marcaram o fim de uma prática que o primeiro dos unificadores buscou, com sucesso, extirpar. No século XVI, chamar organizações religiosas que possuíam exércitos organizados em ligas (Ikki) para auxiliar em guerras maiores passou a ser algo largamente aceito e praticado. Os seguidores da seita Jōdō (Terra Pura), submetidos ao templo Honganji - que entre 1570 e 1580 engajaram-se numa longa guerra contra Nobunaga ${ }^{369}$ - já haviam, desde o início do século, se envolvido em diversas guerras que envolviam inclusive membros do shogunato Ashikaga. ${ }^{370}$

$\mathrm{O}$ fato de que as duas maiores ligas religiosas - Ikkō Ikki (seita da Terra Pura) e Hokke Ikki (seita Nichiren) - provirem justamente de seitas budistas relativamente exclusivistas $^{371}$, que enfatizavam o senso de solidariedade entre os membros, salta aos olhos pela similaridade com o cristianismo.

O poder das instituições religiosas representava ainda um maior perigo para líderes como Nobunaga, pois exércitos da ligas Ikki eram compostos não de mercenários, mas de membros (no caso das ligas $I k k \bar{o}$ mesmo sendo membros da seita muitos dos integrantes do exército eram guerreiros profissionais e semi-profissionais), o que facilitava o recrutamento inclusive no tocante às questões financeiras. Além disso, as instituições religiosas eram capazes de oferecer outros motivos para o engajamento nas batalhas que o poder temporal não - como ocorreu no caso das guerras de 1570 contra Nobunaga que o Honganji utilizou-se tanto de um incentivo positivo, afirmando que aqueles que morressem no campo de batalha renasceriam no paraíso, quanto de um negativo, ameaçando de excomunhão àqueles que não atendessem ao pedido de recrutamento $^{372}$.

As batalhas das ligas religiosas contra Nobunaga, apesar de extremamente exaustivas para ambos os lados, acabaram favoráveis ao líder unificador e de forma dramática para as instituições religiosas. A sangrenta invasão, em 1571, do mais importante centro budista do Japão - o Enryakuji, mosteiro da seita Tendai no monte Hiei -, assim como o acordo forçado com os seguidores da seita Terra Pura (a fim de

\footnotetext{
${ }^{369}$ Foram as campanhas militares entre a ligas Ikkō Ikki e Oda Nobunaga.

${ }^{370}$ Ver TSANG, Carol. Op. Cit.

${ }^{371}$ Relativamente exclusivistas porque apesar de não haver uma interdição oficial de outras práticas pregavam que somente alguns ritos, trazidos e ensinados pelos seus líderes, bastavam para que o indivíduo alcançasse o "paraíso".

372 TSANG, Carol. Op. Cit., pag. 199.
} 
evitar semelhante massacre), em 1580, em Ishiyama, marcaram o fim de uma política presente no período Sengoku de prioridade da lei budista buppō sobre a lei secular $\bar{o} b \bar{o}^{373}$

Nobunaga, por outro lado, também procurou minar o poder social e econômico dos templos e monastérios, buscando assim reduzir drasticamente o poder $\mathrm{e}$ independência adquiridos pelos mesmos nos séculos anteriores. Porém, não se pode sugerir, como já foi colocado no primeiro capítulo, que o líder tomara tais atitudes por qualquer antipatia religiosa ao budismo. Assim como não se pode sugerir que ele tenha facilitado o caminho dos padres jesuítas por qualquer simpatia com a doutrina cristã. $\mathrm{O}$ embate entre ambas as religiões fez do cristianismo um aliado natural de Nobunaga, naquele contexto.

Contudo, ao contrário do que os missionários poderiam suspeitar, o fato de Nobunaga ter tido sucesso em sua empreitada contra os monastérios e templos budistas fez com que a vantagem de não ser budista, em 1580, se tornasse uma desvantagem na década seguinte. Como afirmou Peter Nosco: "Hideyoshi era flexível e preparado para mudar sua política religiosa sempre que necessário para servir seus fins políticos ou militares" ${ }^{374}$ E o contexto político modificou-se na década de 1580 , de forma que o segundo dos unificadores precisou mudar completamente a atitude perante o cristianismo no Japão. A religião estrangeira deixara, portanto, de ser uma aliada para tornar-se uma ameaça em potencial.

Tal constatação parece ter fugido aos olhos sempre tão atentos dos missionários cristãos (lembrando que, na época da expulsão e nos anos seguintes, não apenas os jesuítas, mas também outras ordens católicas trabalhavam no território japonês), que continuaram suas discussões acerca de métodos evangelizatórios, principalmente após a chegada dos franciscanos no arquipélago.

O novo Estado moderno japonês conferia um papel diferente do proposto até o período Muromachi à religião. As atitudes tomadas primeiramente por Nobunaga na

\footnotetext{
${ }^{373}$ Tal política poderia ser mais facilmente aplicada na ausência de um verdadeiro poder central, como ocorreu no período Sengoku. Ver: NOSCO, Peter. Early Modernity and the State's Policies toward Christianity in $16^{\text {th }}$ and $17^{\text {th }}$ century Japan. Bulletin of Portuguese/Japanese studies, dez., ano/vol 7, Lisboa: Universidade Nova de Lisboa, p. 7-21, 2003.

${ }^{374}$ NOSCO, Peter. Japanese Policy Toward Religions in the 'Christian' Century. O Século Cristão do Japão: actas do colóquio internacional comemorativo dos 450 anos de amizade Portugal-Japão (15431993). Lisboa, Nov-1993, p. 571 (tradução minha).
} 
reunificação e posteriormente por Hideyoshi e os Tokugawa ${ }^{375}$ em relação às instituições budistas eram sintomáticos desse "novo papel”.

Em 1615, segundo Peter Nosco, o Bakufu já havia baixado quarenta e quatro éditos dirigidos a templos específicos ou seitas budistas como um todo, como parte de um esforço para colocar as principais seitas a serviço do Estado ${ }^{376}$. As tentativas do segundo xogum Tokugawa, Hidetada, em regulamentar as atividades dos praticantes de religiões externas às seitas, como os ascetas das montanhas, conhecidos como yamabushi, demonstram um esforço para controlar não apenas atos, mas também pensamentos e palavras. A fé pessoal poderia ser, pela primeira vez no Japão, um perigo, um crime. ${ }^{377}$

Um novo lugar fora conferido à privacidade no que se refere às crenças pessoais e à religião. Para além das suas crenças e práticas, esta passou a ter um forte papel político no Japão Moderno.

As querelas entre o Bakufu e organizações budistas não cessaram na era Edo. Em 1627, o xogum ordenou o cancelamento do shie ${ }^{378}$ concedido pelo imperador aos prelados de dois templos e, em 1630, o Bakufu sofreu um sério embate com os seguidores "fundamentalistas" da seita Nichiren ${ }^{379}$. Muito mais do que mostra de uma oposição ao poder central por parte de determinadas organizações budistas, tais embates demonstram uma preocupação constante por parte do Bakufu com a religião e suas práticas.

A supressão do budismo - à semelhança do que fora feito com o cristianismo jamais foi vislumbrada por qualquer dos unificadores ou xoguns Tokugawa. O Bakufu continuou patrocinando templos budistas, assim como se utilizando dos mesmos para fins de controle social. Peter Nosco afirma até mesmo que o budismo funcionou, em certo sentido, como uma religião de Estado e foi instrumental para descobrir as atividades de religiões proibidas ${ }^{380}$ (basicamente o cristianismo). A obrigatoriedade em registrar nascimentos, mortes e casamentos no templo budista local (conhecido por

\footnotetext{
${ }^{375}$ Basicamente os três primeiros xoguns Tokugawa: Ieyasu (r. 1603-1605), Hidetada (r. 1605-1623) e Iemitsu (r. 1623-1651).

${ }^{376}$ NOSCO, Peter. Op. cit. (2003).

377 Ibidem, p. 12.

${ }^{378}$ Manto cedido a determinados prelados. Considerado uma grande honra.

${ }^{379}$ NOSCO, Peter. Op. cit. (2003), p. 13.

${ }^{380}$ Ibidem, p. 12-13.
} 
terauke shōmon), instituída em 1613 e 1614, mas aplicado nacionalmente somente em 1635 durante o governo do terceiro xogum Tokugawa, Iemitsu ${ }^{381}$, é exemplo claro disso.

Com relação ao cristianismo, Nosco defende que, embora este tenha permanecido como uma religião estrangeira para os japoneses ${ }^{382}$, contribuiu para a sua modernidade, pois ajudou a construir um senso de religião como uma importante esfera distinta da atividade humana ${ }^{383}$.

Por parte dos missionários, entretanto, creio que houve uma ênfase muito grande na esfera privada da religião, como uma associação voluntária por parte do indivíduo, justamente naquilo em que a acomodação trabalha, e um descuido, se é que se pode chamar assim, para com a esfera pública. E foi justamente aí que a missão cristã falhou.

A proposta arquitetada por Valignano é inegavelmente de uma engenhosidade sem precedentes no que diz respeito à expansão do cristianismo, muito embora tenha havido vozes dissonantes dentro e, principalmente, fora da Companhia. Contudo, a expulsão dos missionários, assim como a proibição do cristianismo no Japão, pouco teve a ver com as discussões acaloradas acerca do método evangelizatório. A dimensão política que tanto as práticas quanto a doutrina cristã poderiam ter não foi objeto de discussão dos missionários, que acabaram por não perceber o perigo que o cristianismo poderia representar para as autoridades japonesas.

Muito embora as religiões, tanto a cristã quanto a budista, sempre tenham tecido ao longo do tempo relações ora de aporte, ora de conflito para com os poderes instituídos, a novidade da mensagem cristã, assim como o 'descuido político' por parte de seus missionários, acabou resultando na extirpação total, ou ao menos na tentativa de tal por parte das autoridades centrais, do cristianismo do Japão por toda a era Edo.

\section{ACOMODAÇÃO - UMA NOVA MENTALIDADE}

Apesar de o resultado final, ao menos para o Japão, não ter sido o esperado nem o almejado pelos jesuítas, não se pode fazer pouco caso do método acomodacionista, tendo em vista tudo aquilo que ele representou, não apenas para os agentes do mesmo

\footnotetext{
${ }^{381}$ NOSCO, Peter. Op. cit. (1993), p. 579.

${ }^{382}$ No sentido em que não fora incorporada essencialmente pela sociedade em geral, já que o fenômeno dos kakure kishitan é pontual.

${ }^{383}$ NOSCO, Peter. Op. cit. (2003), p. 17.
} 
(os próprios jesuítas), como para o público alvo: os japoneses conversos ${ }^{384}$. Um estudo mais apurado do fenômeno dos kakure kirishitan provavelmente traria mais informações acerca das consequências de longo prazo que tal método representou para os japoneses.

O presente estudo, contudo, foca sua análise nas experiências e impressões dos agentes de tal processo: os missionários jesuítas, especificamente. A querela de Valignano com Cabral foi apenas a primeira, e provavelmente a menos carregada de consequências, das contendas provocadas pela proposta de método acomodacionista. Cabral, apesar de mais conservador, fazia parte também dos jesuítas cuja mentalidade diferia fundamentalmente daquela das ordens mendicantes. A entrada destes no Japão e a expulsão dos missionários do seu território provocaram uma enxurrada de críticas aos métodos evangelizatórios dos jesuítas, às quais a Companhia foi obrigada a responder no século seguinte (XVII). Já em 1598, Valignano escreveu a Apologia en la cual se responde a diversas calumnias que se escrivieron contra los P.P. de la Compañia de Jesus de Japón y de la China, na qual refutava as acusações feitas no ano anterior pelo padre franciscano Martin de la Ascención ${ }^{385}$. Em seu tratado, frei Martin criticava os métodos de missionação dos jesuítas, seu programa de formação de um clero de origem japonesa, a maneira de os jesuítas vestirem-se de forma adequada aos costumes sociais japoneses, o esforço para um diálogo cultural e o intercâmbio de caráter científico que promoviam. $^{386}$

Em 1624, foi a vez do padre jesuíta Valentim Carvalho ${ }^{387}$ escrever um tratado defendendo a Ordem das críticas dos mendicantes. A Apologia e resposta feita pelo Pe. Valentim Carvalho da Companhia de Jesus, Provincial nesta província de Japão e China a hum tratado do Pe. Frei Sebastião de São Pedro da Ordem de S. Francisco que

\footnotetext{
${ }^{384}$ No caso específico da missão estudada, o público alvo eram os japoneses. Vimos, contudo, que o método foi experimentado também em outras terras.

${ }^{385}$ Martin de La Ascención afirma em seu tratado que os franciscanos não se negavam a "conformar-se" aos japoneses, mas somente "fuera de lo que toca a la observância regular de nuestra Sagrada Religión" e daí a crítica aos jesuítas que não o fariam também dessa maneira. Trecho retirado de: Martin de la Ascención. Relaciones I. 1597 In: TALADRIZ, José Luis Alvarez (Ed.). Relaciones e Informaciones Documentos Franciscanos de la Cristandad de Japón (1593-1597), Osaka, 1973. Para mais informações ver também: FRANCO, José Eduardo. Jesuítas e Franciscanos perante às culturas e religiões do Extremo Oriente: o caso da Apologia do Japão e a dramática missionação das Ilhas do Sol Nascente. Revista de História Unisinos, vol. 11, $\mathrm{n}^{\circ}$ 2, Lisboa: maio-agosto 2007, 210-221.

${ }^{386}$ FRANCO, José Eduardo. Introdução, In: FRANCO, José Eduardo e LOPES, Cristina, CARVALHO, Apologia do Japão. Lisboa: Tipografia Peres, 2007.

${ }^{387}$ Valentim Carvalho (1560 Lisboa - 1631 Goa). Foi de 1611 a 1617 o primeiro provincial do Japão e da China.
} 
se intitula 'Recopilação das causas, porque o Imperador do Japão desterrou de seus Reinos todos os Padres' inclui uma cópia traduzida para o português pelo próprio Valentim da obra integral do franciscano, citada no título. ${ }^{388}$

As polêmicas geradas pela proposta de acomodação se devem, em grande parte, à grande novidade que ela representava no momento. Ao propor a imitação de determinados costumes e rituais, propunha também a separação do social e do religioso, do público e do privado ${ }^{389}$.

Além disso, abria espaço para a diversificação do cristianismo e suas práticas, uma vez que as sociedades pagãs poderiam, a partir desta ótica, inserir-se nele sem que isso significasse a subversão dos seus hábitos civis locais. Até então, a evangelização tinha tido como modelo um cristianismo uniformizado tanto nas questões essenciais da fé quanto dos pormenores da vida cotidiana ${ }^{390}$.

O método da acomodação jesuítica tem origem, portanto, numa mentalidade moderna de missionação. Menos providencialista e teocêntrica e mais 'empresarial', tal método buscava a racionalização dos meios em função das circunstâncias culturais e mentais dos povos missionados, a fim de atingir o objetivo final da atividade missionária: a conversão. Apesar de compartilhar de um mesmo fim, a acomodação emerge já em confronto com a mentalidade marcada pela mundivivência medieval do proselitismo cristão, assente na providência divina e numa visão miraculosa da evangelização. Para José Eduardo Franco, os jesuítas possuíam:

uma visão da atividade missionária que, sem desconsiderar a assistência divina, não descura a necessidade e a importância de investir em meios materiais e humanos e em recriar e adequar estratégias missionárias racionalmente adaptadas aos diferentes 'cenários' do trabalho de pregação, de anúncio da doutrina cristã. ${ }^{391}$

Uma visão totalmente diferente daquela influenciada pelo pensamento medieval e praticada pelos franciscanos. Para estes, a inteligência subjetiva e a capacidade do missionário de interpretar o mundo no qual estava inserido eram absolutamente rejeitados. O missionário deveria, através de seu comportamento, manter-se alheio aos

\footnotetext{
${ }^{388}$ Tal obra encontra-se perdida e, portanto, sua tradução por Carvalho é a única versão que temos dela.

${ }^{389}$ Peter Nosco afirma até mesmo que o cristianismo contribuiu para a Modernidade japonesa na construção de uma esfera pública separada da privada. Ver: NOSCO, Peter. Op. cit. (2003), p. 17.

${ }^{390}$ COSTA, João Paulo de Oliveira. Op. Cit. (1998), p. 46-47.

${ }^{391}$ FRANCO, José Eduardo. Op. Cit., p. 218.
} 
valores mundanos. Qualquer inovação apareceria, portanto, como uma modificação da Verdade absoluta transmitida pela Igreja (instituição que personificava tal verdade). Certos de que representavam a verdadeira Igreja, os franciscanos não concebiam a mensagem evangélica dissociada da tradição. ${ }^{392}$ Vista desta perspectiva a mudança implicaria sempre numa decadência. Indício disso é a conotação do termo modernitas, que na Idade Média era negativa ${ }^{393}$.

Os jesuítas partem de premissas essencialmente diferentes de tal pensamento. A apurada educação intelectual dos membros da ordem, assim como seu caráter fortemente anti-monástico mostram que tanto o conhecimento quanto a experiência eram fundamentais para a prática evangélica.

Os textos de Inácio de Loyola, como as Constituições ou os Exercícios Espirituais, evidenciam uma nova compreensão da natureza humana e da relação do sujeito com o mundo. Ainda que os jesuítas concordassem com o princípio aristotélico de que o Homem possui uma inclinação natural para a busca da perfeição no encontro com a suprema causa divina, tal encontro seria condicionado pela natureza e pelas perspectivas do ser em questão, ou seja, dos seus meios e capacidades. Assim, a idéia pregada por São Francisco de Assis, proveniente de um cristianismo neo-platônico, de que a natureza é um reflexo de Deus, deixava de ter sentido, pois o plano natural dissociava-se do sobrenatural ${ }^{394}$.

Tal perspectiva abre espaço para o reconhecimento da diversidade, antes vista como produto de um mundo pecaminoso. A idéia da diversidade, por sua vez, é central para a compreensão da acomodação jesuítica e Valignano tinha total noção disso. No seu Sumário, ao falar da grande diferença existente entre europeus e japoneses, ele

\footnotetext{
${ }^{392}$ CORREIA, Pedro Lages Reis, Alessandro Valignano attitude towards Jesuit and Franciscan concepts of evangelization in Japan (1587-1597), Bulletin of Portuguese/Japanese studies, junho, ano/vol 2, Lisboa: Universidade Nova de Lisboa, p. 79-108, 2001.

${ }^{393}$ Ibidem, p. 88.

${ }^{394}$ Ibidem, p. 93. Essa controvérsia obviamente não se restringiu ao contexto das missões asiáticas, mas foi motivo de acaloradas discussões acadêmicas e teológicas nas universidades européias, particularmente de Paris e Salamanca. Para mais informações consultar: ZERON, Carlos Alberto Moura Ribeiro. La Compagnie de Jésus et l'instituition de l'esclavage au Brésil: lês justifications d'ordre historique, théologique ET jurudique, ET leus intégration par une mémoire historique (XVI-XVII siècles), Paris: EHESS, 1998, pag. 212-214, nota 15.
} 
afirmou que tal contrariedade era tão grande "que no parece accidental sino intrínseca y natural por ser como fundada en la naturaleza, 395 .

Para os jesuítas, portanto, as diversidades do mundo ao redor deveriam ser levadas em conta e a Igreja deveria procurar uma maneira de integrar-se neste ambiente. Daí o tom anti-monástico da ordem, defendida por Loyola. Para ele não haveria um local sagrado (monastério) por oposição a um mundo externo pecaminoso. Seus Exercícios Espirituais propõem justamente um estilo de vida em harmonia com Deus para além da reclusão dos monastérios.

Diferente da perspectiva medieval, para os jesuítas,

A interpretação da mensagem divina não é uma externalização de um subjetivo e apriorístico conceito de Deus. Há a aceitação do fato de que a Divina Providência pode se manifestar de uma maneira diferente da que o missionário prevê. Nesta conceitualização da relação com Deus, a experiência é considerada como conceito fundamental, uma vez que se torna o caminho para avaliar os sinais enviados pela Divina Providência, e portanto demonstra uma mentalidade aberta às manifestações de Deus no mundo. ${ }^{396}$

Daí a valorização da razão e da inteligência para o missionário, algo tão presente nas cartas dos jesuítas analisadas no presente trabalho. Ao reconhecer a diversidade presente no outro, o missionário passa a reconhecer também a necessidade da procura de um 'meio caminho' para possibilitar a evangelização.

\footnotetext{
${ }^{395}$ VALIGNANO, Alexandre, Sumario de las Cosas de Japon, In: TALADRIZ, J. C. Alvarez, op. cit., p. 198.

${ }^{396}$ CORREIA, Pedro Lages Reis. Op. Cit., p. 95, (tradução minha).
} 


\section{CONSIDERAÇÕES FINAIS}

“(...) eu defino 'crença' não como um objeto em que se acredita (um dogma, programa, etc.), mas como um investimento do sujeito num projeto, o ato de dizê-lo e considerá-lo como verdadeiro". 397

Embora o historiador, assim como qualquer ser humano, seja incapaz de despojar-se completamente das suas convicções e valores para estudar uma sociedade num outro tempo e espaço, afinal ele também é produto - ainda que não passivo - de seu tempo, ele deve esforçar-se ao máximo para compreender os sujeitos de seu estudo através de seus próprios conceitos.

A definição feita acima por Michel de Certeau de "crença" amplia consideravelmente seu escopo. E isso é essencial para compreender o estudo em questão. Ao me propor a estudar as propostas de evangelização para os japoneses, feitas pelos jesuítas no século XVI, não poderia me restringir nem acreditar que investigaria então somente práticas religiosas, assim como as compreendemos no século XXI. A dissociação do "político" e do "sacro" foi algo gestado e proposto pela Modernidade 398 - embora jamais possa ser uma tarefa absolutamente terminada, afinal ideias não são como objetos que podem ser separados em gavetas ou arquivos ou, como afirma Mircea Eliade, "uma tal existência profana jamais se encontra no estado puro"399 - portanto justamente no momento em que nossos sujeitos em questão (jesuítas e japoneses do século XVI) viveram.

A religião naquele momento, portanto, foi a lente pela qual os nossos agentes, missionários jesuítas, procuraram entender o outro (no caso o japonês) e ao proporem diferentes formas de evangelização deste povo elaboraram diferentes propostas de os inserirem na sua visão de mundo, o cristianismo. Assim, creio poder dizer que são testemunhas de um encontro de dois povos, que até então jamais haviam entrado em contato.

Fica claro, no entanto, que trata-se de testemunhos de apenas um dos lados da relação construída: os missionários cristãos europeus. A tentativa de compreender o outro lado da relação fica manca, uma vez que não se deu voz aos japoneses. Contudo,

\footnotetext{
${ }^{397}$ CERTEAU, Michel de. The Practice of Everyday Life, (tradução Steven Rendall), Berkley: University of California Press, 1988, pag. 178. (tradução minha).

${ }^{398}$ CERTEAU, Michel de. Op. Cit.,(2000), pag. 127.

${ }^{399}$ ELIADE, Mircea. O Sagrado e o Profano - A essência das religiões, (tradução Rogério Fernandes), São Paulo: Martins Fontes, 1992, pag. 27.
} 
não se pode dizer que foram tratados aqui como sujeitos passivos. Foram justamente os japoneses que escolheram e inclusive impuseram aos europeus o fim da missão em seu território, como foi colocado nos capítulos anteriores.

Tanto os comerciantes europeus quanto missionários cristãos testemunharam um momento de crise e viragem na história japonesa e pouco puderam influenciar nos resultados advindos desse momento histórico, como pudemos ver no primeiro capítulo da presente dissertação. Tanto a "benevolência" de Nobunaga para com os padres e cristãos, quanto a expulsão dos mesmos por parte de Hideyoshi ou a perseguição implacável promovida pelos Tokugawa no século XVII, pouco tiveram a ver com as estratégias usadas pelos jesuítas no seu trabalho missionário no Japão. Vimos que na centralização do poder levada a cabo pelos líderes unificadores e mantida pelos Tokugawa por toda a Era Edo, a elite militar japonesa escolheu seus próprios caminhos para a nação, caminhos estes que não deixavam espaço para uma doutrina estrangeira como o cristianismo.

Ainda assim, é admirável como os jesuítas, ignorantes do contexto histórico japonês, conseguiram sobreviver a um contexto de guerras civis intestinas. Quando Xavier chegou ao arquipélago com João Fernandez e Cosme de Torres e por todo o primeiro superiorato (até 1570), os missionários montaram e desmontaram suas missões no território japonês num clima de total instabilidade. Fugindo de guerras e perseguições promovidas por daimyō hostis e a procura de abrigo e patronos, os jesuítas sobreviveram às intrigas políticas de um período de guerra total, como os próprios japoneses denominam esse era (Sengoku Jidai). Ainda que numa situação de total insegurança, é digno de nota o fato de que, nesse primeiro momento, nenhum missionário tenha sido preso ou morto quer pelo poder central quer pelos daimyō. Além disso, os poucos missionários presentes no Japão durante o primeiro superiorato foram capazes não apenas de levar adiante a missão como de convencer as autoridades jesuítas a apostarem no sucesso da mesma e continuarem a mandar fundos e obreiros.

Alcançando certa estabilidade durante o segundo superiorato - graças à conversão de alguns daimyō e à pacificação do território advinda da unificação política que estava sendo levada a cabo por Nobunaga - os jesuítas se viram então envolvidos em acaloradas controvérsias internas à ordem acerca do melhor método evangelizatório para os japoneses. O superior da missão, Francisco Cabral, e o Visitador Geral das 
Índias Orientais, Alexandre Valignano, protagonizaram a primeira das querelas entre os agentes cristãos que a missão japonesa se viu envolvida na Modernidade. O triunfo de Valignano, e consequentemente do método acomodacionista, demonstrou uma adesão, por parte dos jesuítas, a uma nova forma de se pensar missão e evangelização, ao menos para alguns povos.

Ironicamente, assim que o sucessor de Oda Nobunaga, Toyotomi Hideyoshi, terminou a unificação, ele se voltou pela primeira vez para o elemento estrangeiro proibindo a presença e atividade dos missionários cristãos no arquipélago. Com poucos recursos para virar o jogo, os jesuítas pouco puderam fazer além de retardar um processo já em curso: a política de fechamento da nação - sakoku.

Com a morte de Hideyoshi na Coréia e a confirmação do clã Tokugawa no poder - com a batalha de Sekigahara em 1600 e a invasão do Castelo de Osaka em 1614 - as ricas controvérsias acerca dos métodos evangelizatórios, primeiramente protagonizadas por Valignano e Cabral e posteriormente entre jesuítas e franciscanos, ficaram cada vez mais longe de terem um sentido prático, ao menos no que diz respeito ao povo em questão: os japoneses.

O método da acomodação, arquitetado por Valignano, teve curta duração na sua aplicação dentre os japoneses, muito embora ele tenha sido aproveitado em outros territórios de missão na Ásia. No entanto, a defesa do mesmo, materializada nas duas obras de Valignano: Sumário de las Cosas de Japon - na qual ele faz a defesa do método tendo em vista as críticas internas da Companhia - e a Apologia en la cual se responde a diversas calumnias que se escrivieron contra los P.P. de la Compañia de Jesus de Japón y de la China - que contém a defesa da Ordem contra as críticas dos franciscanos - sobreviveu à missão e foi largamente divulgada na Europa. É difícil dizer se o método ou as obras tiveram alguma influência em outras missões, uma vez que o estudo em questão não foi dirigido neste sentido, mas sabemos que pelo menos dentre os missionários em atividade nas chamadas Índias Orientais foram amplamente lidas. Além disso, sabemos que as cartas dos jesuítas nas missões viajavam bastante para serem lidas e compartilhadas por seus companheiros nos mais diferentes lugares. As cartas do primeiro superior do Japão, Cosme de Torres, por exemplo, serviram de base 
de informação acerca do povo japonês para o famoso jesuíta da missão peruana, José de Acosta. $^{400}$

No entanto, mais do que seu impacto na prática missionária, procuramos trabalhar aqui com o método acomodacionista como expressão de uma série de fatores combinados. A formação do jesuíta, a sua vocação para trabalhos missionários, o encontro com diversos povos e a realidade política e cultural do Japão, contribuíram para a formulação de um método que propunha em primeiro lugar a transformação do agente evangelizador, antes mesmo do sujeito a ser evangelizado.

Mas, se o encontro com os mais diferentes povos, desde as Américas até o Extremo Oriente da Ásia, promovido pelas Grandes Navegações Ibéricas, obrigou a reformulação de antigos paradigmas, a forma como essa mudança se operou dependeu do agente missionário e do povo em questão, ou seja, dos dois sujeitos participantes do encontro.

Ao analisar as posições dos teólogos da segunda metade do século XVI diante dos problemas de ordem moral suscitados pela colonização do chamado Novo Mundo, Carlos Zeron afirma que:

“(...) a diversidade dos povos periféricos, de seus costumes e modos de organização política são medidos e confrontados com a lei europeia-cristã, apresentada a priori como idêntica e válida para todos."

Portanto, ainda que cada agente e cada encontro tenha delineado uma diferente "saída", fica claro que a atitude dos europeus diante de todas as novidades colocadas pelos diversos encontros foi o confronto com seus padrões e valores, compreendidos como "válidos para todos". Ainda assim, tanto para leste quanto para oeste, a expansão europeia, ao promover uma série de novos encontros, obrigou os agentes europeus a encararem novas situações, que por sua vez trouxeram novos problemas, práticos e morais, que foram resolvidos e justificados das mais diversas formas.

\footnotetext{
400 VIGNERON DE LA JOUSSELANDIÈRE, Victor Santos. Converter civilizar comunicar. Considerações sobre religião, direito e linguagem no Peru colonial. Dissertação (mestrado em História) - Departamento de História Social da Faculdade de Filosofia Letras e Ciências Humanas na Universidade de São Paulo, São Paulo, 2012.

${ }^{401}$ ZERON, Carlos Alberto de Moura Ribeiro. Linha de Fé - A Companhia de Jesus e a Escravidão no Processo de Formação da Sociedade Colonial (Brasil, Séculos XVI e XVII), tradução de Antonio de Padua Danesi, São Paulo: Edusp, 2011, pag. 191.
} 
Para o caso japonês (e para outros casos asiáticos como a China), Valignano e os outros jesuítas sentiram a necessidade de uma abordagem que propusesse a transformação do agente missionário cristão. O fator pragmático da falta de poder coercivo dentre os japoneses, assim como a respeitabilidade da cultura e costumes japoneses dentre os europeus (que, como vimos, a consideravam altamente refinada, ainda que diferente ou até oposta a européia), contaram igualmente, a meu ver, para que os jesuítas propusessem um método evangelizatório como a "acomodação".

Por outro lado, o fato de os costumes e hábitos japoneses serem considerados pelos europeus como refinados, diz respeito muito mais à cultura que os classificou assim (missionários cristãos europeus), do que aos costumes japoneses em si. Como já foi discutido no terceiro capítulo do presente trabalho, ao caracterizarem os hábitos e costumes japoneses como absolutamente opostos aos europeus, os missionários jesuítas (enfatizaria aqui o papel de Valignano e Luis Fróis) abriram um espaço de compreensão da alteridade que não foi aberta para o caso americano. Afinal, os japoneses foram considerados diferentes dos europeus, mas lhes foi dada a possibilidade de inserir-se na religião cristã sem que tivessem que abdicar de seus costumes civis.

A acomodação, proposta inicialmente para o Japão, mas posteriormente exportada para outras missões asiáticas, teve por fim então somente esse "tipo de civilização", a saber, o mais alto grau de civilização dentre as populações bárbaras. Os jesuítas dos séculos XVI e XVII que formularam tal classificação dividiram as populações extra-europeias (chamadas então de bárbaras) em três graus hierárquicos. Os japoneses, juntamente dos chineses, foram então classificados como pertencentes ao mais alto grau de "civilização na barbárie" 402 . Os critérios de tal classificação analisavam a linguagem (oral e escrita, se houvesse), religião, ritos civis dentre outros. Contudo, como apontado por Carlos Zeron no trecho já citado acima, a diversidade desses povos foi confrontada com a lei europeia-cristã. Em outras palavras, podemos dizer que o sistema de pensamento cristão-europeu do século XVI era um sistema autoreferencial e, portanto, se colocava a tarefa de encontrar todas as respostas dentro do seu próprio sistema de referência. Assim, ao classificar os japoneses e chineses como pertencentes ao mais alto grau de civilização dentre os bárbaros (situação da qual não

\footnotetext{
${ }^{402}$ Podemos citar aqui o jesuíta José de Acosta, missionário no Peru. Sobre essa classificação e seus critérios ver: VIGNERON DE LA JOUSSELANDIÈRE, Victor Santos. Op. Cit., pag.41-56. E AGNOLIN, Adone.Op. Cit. (2007).
} 
podiam escapar por não serem cristãos), pode-se dizer que os missionários viram nessas duas populações costumes e hábitos diferentes, mas analisáveis segundo seus padrões e, portanto, seriam aceitáveis.

Ainda assim, mesmo dividindo as populações não europeias em diferentes graus de civilização, os missionários cristãos foram capazes de formular uma base comum a todos os povos, inclusive europeus: a humanidade como possuidora da faculdade da razão ${ }^{403}$. Ainda que os povos pudessem estar em diferentes estágios de racionalidade todos os seres humanos seriam capazes de fazer uso da razão. Tal base compartilhada seria capaz de justificar o processo de evangelização da humanidade (afinal todos poderiam compreender o Evangelho fazendo uso da razão, diferente dos outros animais, não racionais).

O caso da missão japonesa, ainda que bastante breve comparada a outras missões, é exemplar por ter resultado numa estratégia de conversão que obrigou um sistema auto-referencial a se reformular em determinados aspectos (como a não imposição de costumes civis e até mesmo adoção de outros por parte dos agentes evangelizadores) por se ver incapaz de encaixar sua doutrina numa determinada estrutura sem que ela mesma tivesse que ser modificada. Se o cristianismo, até o século XVI, era visto como indissociável de determinados costumes europeus, a proposta de acomodação inicia a desvinculação do civil e religioso como principal estratégia para conversão de povos gentios.

\footnotetext{
${ }^{403}$ AGNOLIN, Adone. Op. Cit. (2007).
} 


\section{Bibliografia}

\section{Referências documentais:}

CARVALHO, Padre Valentim de. Apologia e resposta feita pelo Pe. Valentim Carvalho da Companhia de Jesus, Provincial nesta província de Japão e China a hum tratado do Pe. Frei Sebastião de São Pedro da Ordem de S. Francisco que se intitula 'Recopilação das causas, porque o Imperador do Japão desterrou de seus Reinos todos os Padres(1627), In: FRANCO, José Eduardo e LOPES, Cristina, Apologia do Japão, Lisboa: Tipografia Peres, 2007.

COOPER, Michael (org). They came to Japan. An anthology of European reports on Japan (1540-1640), Londres: Thames and Hudson, 1967.

FRÓIS, Luis. Europa Japão: um diálogo civilizacional no século XVI: tratado em que se contêm muito sucinta e abreviadamente algumas contradições e diferenças de costumes entre a gente de Europa e esta província de Japão (...), Lisboa: Comissão Nacional para as Comemorações dos Descobrimentos Portugueses, 1993 [1597].

. História de Japam, cinco volumes, Lisboa: Biblioteca Nacional de Lisboa, 1976 [manuscrito de 1597].

GARCIA, José Manuel (ed.). Cartas que os Padres da Companhia de Iesus Escreverão dos Reynos de Iapão e China aos da mesma Companhia da Índia e Europa des do anno de 1549 até o de 1580, 2 volumes, Maia, Cotovia, 1997.

LOYOLA, Ignácio de (santo), Constituições da Companhia de Jesus e normas complementares, São Paulo: Loyola, 1997.

MEDINA S.J., J. Ruiz de (ed.). Documentos de Japón 1547-1557, Roma, Institutum Historicum Societatis Iesu, 1990.

- Documentos de Japón 1558-1562, Roma, Institutum

Historicum Societatis Iesu, 1995.

RODRIGUES, Francisco. Resposta que alguns padres de Japão mandaram perguntar. 1570. In: PINTO, Ana Fernandes e PIRES, Silvana Remédio. The 'Resposta que alguns padres de Japão mandaram perguntar': a clash of strategies. Bulletin of 
Portuguese/Japanese Studies, Lisboa: Universidade Nova de Lisboa, Vol. 10-11, Junho-Dezembro, p. 9-60, 2005.

Regras da Companhia de Jesus. Conforme edição de 1582. Lisboa, S.N., 1877.

TALADRIZ, José Luis Alvarez (Ed.). Relaciones e Informaciones - Documentos Franciscanos de la Cristandad de Japón (1593-1597), Osaka, 1973.

TAKESHI, Morita; DOI, Tadao; CHONAN, Minoru. Nippo Jisho: Hoyaku 邦訳日葡辞 書, Tóquio: Iwanami Shoten, 1980 (1603).

VALIGNANO, Alexandre, Sumário de las Cosas de Japón, 1583. In: TALADRIZ, J. C. Alvarez, Monumenta Nipponica Monographs, Tóquio: Sophia University, v. 9, 1954.

VALIGNANO, Alexandre. Advertimentos e Avisos Acerca dos Costumes e Catangues do Jappão. (1583). In: SCHÜTTE S.J., Giuseppe Franz. Il Cerimoniale per $i$ missionari Del Giappone, Roma: Instituto Grafico Tiberino, 1946.

Vocabulario da Lingoa de Iapam, com adeclaração em Portugues, feito por alguns padres, e irmãos da Companhia de Iesu.1603. Tóquio: Iwanami Shoten, 1960, (edição fac-símile).

WICKI S.J., Joseph; GOMES S.J., John (eds.). Documenta Indica (1592-1594), v. XVI, Intitutum Historicum Societatis Iesu, Roma, Via dei Penitenzieri, 1984.

WICKI S.J., Joseph (ed.). Documenta Indica (1595-1597), v. XVII, Intitutum Historicum Societatis Iesu, Roma, Via dei Penitenzieri, 1988.

\section{Referências historiográficas:}

AGNOLIN, Adone. Jesuítas e Selvagens: O encontro catequético no século XVI. Revista de História, São Paulo, Número 144, 2001.

Jesuítas e Selvagens - A negociação da fé no encontro catequético-ritual americano-tupi (séculos XVI-XVII). São Paulo: Humanitas editorial, 2007. 
Religião e Política nos Ritos do Malabar (século XVII):

interpretações diferenciadas da missionação jesuítica na Índia e no Oriente. Cliosérie de revista de pesquisa histórica, S.I., Número 27-1, 2009.

ANDRÉ, Richard. Xintoísmo e culto aos kami: Aproximações e Distanciamentos. Revista Nures, N. 9, maio-dezembro 2008, São Paulo. Disponível em HTTP://www.pucsp.br/revistanures (acesso em 01/03/2012).

ALDEN, Daril. The Making of an Enterprise - The Society of Jesus in Portugal, its empire and beyond 1540-1750, Standford: Standford University Press, 1996.

ARNAUT, Cézar; RUCKSTAOTER, Flávio M. Martins. Estrutura e Organização das Constituições Jesuíticas (1539-1540). Revista Acta Scientiarum, Universidade Estadual de Maringá, vol. 24, número 1, 2002.

BOURDON, Leon. La Compagnie de Jésus et le Japon, Comission Nationale pour les commemorations des decouvertes portugaises, Lisboa-Paris, 1993.

BOXER, Charles Ralph. The Christian century in Japan, 1549-1650, Berkeley: University of California Press, 1951 (1967 printing).

- When the Twain First Met: European Conceptions and Misconceptions of Japan, Sixteenth- Eighteenth Centuries, Modern Asian Studies, Vol. 18, nº 4, Cambridge University Press, 1984.

BROWN, Judith C.. Courtiers and Christians: The First Japanese Emissaries to Europe, Chicago Journals, vol. 47, n 4, University of Chicago Press, 1994.

CASTELNAU, Charlotte. Acomodação aos bárbaros: os jesuítas e os índios tupinambás no Brasil. (cópia gentilmente cedida pela autora).

CERTEAU, Michel de. A Escrita da História. Tradução de Maria de Lourdes Menezes. $2^{a}$ edição, Rio de Janeiro: Forense Universitária, 2000.

. The Practice of Everyday Life, (tradução Steven Rendall), Berkley: University of California Press, 1988.

CORREIA, Pedro Lages Reis. O Triunfo do experimentalismo na missão do Japão: Alessandro Valignano (1539-1606) e a organização da embaixada japonesa à 
Europa em 1582. In: SIMPÓSIO INTERNACIONAL NOVOS MUNDOS NEUE WELTEN. PORTUGAL E A ÉPOCA DOS DESCOBRIMENTOS, Berlim, novembro de 2006.

Francisco Cabral and Lourenço Mexia in Macao (1582-

84): two different perspectives of evangelization in Japan. Bulletin of Portuguese/Japanese Studies, Universidade Nova de Lisboa, vol. 15, dez-2007.

Alessandro Valignano attitude towards Jesuit and

Franciscan concepts of evangelization in Japan (1587-1597), Bulletin of Portuguese/Japanese studies, junho, ano/vol 2, Lisboa: Universidade Nova de Lisboa, p. 79-108, 2001.

COSTA, Célio Juvenal. A Racionalidade Jesuítica: civilização e organização. In: VII SIMPÓSIO INTERNACIONAL PROCESSO CIVILIZADOR, Piracicaba, 2003. Disponível em: http://www.uel.br/grupoestudo/processoscivilizadores/portugues/sitesanais/anais7/Trabalhos/xA\%20racio nalidade\%20jesuitica\%20-\%20civilizacao\%20e\%20organizacao.pdf (acesso em $15 / 10 / 2011)$.

COSTA, João P. Oliveira e. As Relações entre a Índia Portuguesa, a Ásia do Sudeste e o Extremo Oriente, Macau e Lisboa, 1993. . O Japão e o Cristianismo no século XVI - Ensaios de História Luso Nipônica, Lisboa, Sociedade histórica da independência de Portugal, 1999. Oliveira. O Cristianismo no Japão e o episcopado de D. Luis Cerqueira. Tese (doutorado em História dos descobrimentos e da expansão portuguesa) - Faculdade de Ciências Sociais e Humanas da Universidade Nova de Lisboa. Lisboa, 1998.

CRUZ, Bruna Dutra de Oliveira Soalheiro. A Missão Tibetana na Correspondência Jesuíta (1624-1631). Tese (doutorado) - Departamento de História Social da Faculdade de Filosofia Letras e Ciências Humanas da USP, São Paulo, 2009.

CURVELO, Alexandra. A Arte Namban no contexto dos impérios ibéricos. In: SIMPÓSIO INTERNACIONAL NOVOS MUNDOS - PORTUGAL E A ÉPOCA DOS DESCOBRIMENTOS. 23 a 25 de novembro de 2006. Berlim. Disponível 
em: $<$ HTTP://www.dhm.de/ausstellungen/veuewelten/pt/docs/alexandra_curvelo.pdf $>$ (acesso em 01/12/11).

DOUGILL, John. In Search of Japan's Hidden Christians - A Story of Supression, Secrecy and Survival, Tokyo, Rutland, Singapore: Tuttle Publishing, 2012.

ELIADE, Mircea. O Sagrado e o Profano - A essência das religiões, (tradução Rogério Fernandes), São Paulo: Martins Fontes, 1992.

ELISON, George. Deus destroyed: the image of Christianity in early modern Japan, Cambridge, 1973.

ELISON, George e SMITH, Bardwell L. (Ed.).Warlords, Artists and Commoners Japan in the Sixteenth Century.Honolulu: University of Hawaii Press, 1981.

ELISONAS, Jurgis S. A. The Jesuits, the Devil and Pollution in Japan.The context of syllabus of errors.Bulletin of Portuguese/Japanese Studies, Lisboa: Universidade Nova de Lisboa, Vol./ano 1, dez-2000, p. 3-27.

EISENBERG, José. As missões jesuíticas e o pensamento político moderno: encontros culturais, aventuras teóricas. Belo Horizonte: UFMG, 2000.

FIJITA, Neil S. Japan's Encounter with Christianity - The Catholic Mission In PreModern Japan, Nova York, Paulist Press, 1991.

FRANCO, José Eduardo. Jesuítas e Franciscanos perante às culturas e religiões do Extremo Oriente: o caso da 'Apologia do Japão' e a dramática missionação das Ilhas do Sol Nascente. Revista de História Unisinos, vol. 11, $\mathrm{n}^{\circ}$ 2, Lisboa: maioagosto 2007, 210-221.

FRANCO, José Eduardo e LOPES, Cristina, Apologia do Japão, Lisboa: Tipografia Peres, 2007.

FUTIDA, Cristina Ayumi. Institucionalização das Seitas Rinzai e Sōtō Zen no Japão dos Períodos Kamakura e Muromachi. Dissertação (mestrado em Letras) departamento de Letras Orientais da Faculdade de Filosofia, Letras e Ciências humanas da Universidade de São Paulo, São Paulo, 2001. 
HALL, John Whitney (ed.). The Cambridge History of Japan, vol. 4, Cambridge University Press, 1990. Japan - From Prehistory to Modern Times, Tuttle Pub, 2002 (1971).

Foundations of the Modern Japanese Daimyo, The Journal of Asian Studies, S.I., vol. 20, número 3, 1961.

JANEIRA, Armando Martins. O Impacto Português sobre a Civilização Japonesa, Lisboa 1970.

KASAHARA, Kazuo (ed.), A History of Japanese Religion, Tóquio: Tuttle Publishing, 2002.

KURODA, Toshio. The discourse on the 'Land of Kami' (shinkoku) in Medieval Japan. Japanese Journal of Religious Studies, (Tradução Fábio Rambelli), 23/3-4, pp. 353-385.

MAZZOLENI, Gilberto. O Planeta Cultural. Para uma antropologia histórica. Tradução Liliana Laganá e Hylio L. Fernandez. São Paulo: EDUSP, 1992.

LACH, Donald F. Japan in the eyes of Europe, Chicago: University of Chicago Press, 1965.

LONDOÑO, Fernando Torres. Escrevendo Cartas. Jesuítas, Escrita e Missão no Século XVI. Revista Brasileira de História, São Paulo, V. 22, nº 43, p. 11-32, 2002.

LOUREIRO, Rui Manoel. Jesuit Textual Strategies in Japan between 1549 and 1582, Bulletin of Portuguese/Japanese studies, junho, volume 8, Universidade Nova de Lisboa, Lisboa, 2004.

Navios, Mercadorias e Embalagens na Rota Macau-Nagasáqui. Revista de Cultura, Macau, nº 24, 2007.

MATSUDA, Kiichi. The Relations Between Portugal and Japan, Lisboa, 1965.

MONTERO, Paula (org.). Deus na aldeia: missionários, índios e mediação cultural. São Paulo: Globo, 2006. 
MORAN, J. R. The Japaneses and the Jesuits.Alessandro Valignano in sixteenth century Japan, Londres, 1993.

NOSCO, Peter. Early Modernity and the State's Policies toward Christianity in $16^{\text {th }}$ and $17^{\text {th }}$ century Japan. Bulletin of Portuguese/Japanese studies, dezembro, ano/vol 7, Lisboa: Universidade Nova de Lisboa, p. 7-21, 2003.

. Japanese Policy Toward Religions in the 'Christian' Century. $O$ Século Cristão do Japão: actas do colóquio internacional comemorativo dos 450 anos de amizade Portugal-Japão (1543-1993). Lisboa, Nov-1993.

O’MALLEY, John W. Os primeiros jesuitas. Bauru: EDUSC; São Leopoldo: UNISINOS, 2004.

PADEN, Willian E. Interpretando o Sagrado - modos de conceber religião, tradução Ricardo Gouveia, São Paulo: Paulinas, 2001.

PANIKKAR, K. M. Asia and Western Dominance, Unwin, Londres, 1967.

PINA, Isabel. The Jesuit Missions in Japan and in China: two distinct realities. Cultural adaptation and the assimilation of natives. Bulletin of Portuguese/Japanese Studies, Universidade Nova de Lisboa, vol. 2, p. 59-73, jun-2001.

PINTO, Ana Fernandes. Japanese Elites as Seen by Jesuit Missionaries.Perceptions of social and political inequality among the elites. Bulletin of Portugueses/Japanese Studies, Universidade Nova de Lisboa, vol. 1, p. 29-43, dez-2001.

PINTO, Ana Fernandes e PIRES, Silvana Remédio. The 'Resposta que alguns padres de Japão mandaram perguntar': a clash of strategies. Bulletin of Portuguese/Japanese Studies, Lisboa: Universidade Nova de Lisboa, Vol. 10-11, Junho-Dezembro, p. 9-60, 2005.

POMPA, Maria Cristina. Religião como tradução: missionários, Tupi e "Tapuia” no Brasil colonial. Bauru: EDUSC, 2003.

RADULET, Carmen M. O 'Cerimonial' do Padre Alessandro Valignano: encontro de culturas e missionação no Japão. O Século Cristão do Japão: actas do colóquio internacional comemorativo dos 450 anos de amizade Portugal-Japão (15431993). Lisboa, Nov-1993. 
RAVERI, Massimo. Índia e Extremo Oriente: via da libertação e da imortalidade. Tradução Camila Kintzel. São Paulo: Hedra, 2005.

RIBEIRO, Madalena Teotónio Pereira Bourbon. A Nobreza Cristã de Kyūshū. Redes de parentesco e ação jesuítica. Dissertação (mestrado em História) - Faculdade de Ciências Sociais e Humanas da Universidade Nova de Lisboa. Lisboa. 2006.

RUBIÉS, Joan Pau. The Concept of Cultural Dialogue and the Jesuit Method of Accommodation: between idolatry and civilization. In: WORKSHOP JESUITS AS INTERMEDIARIES IN THE EARLY MODERN WORLD, 2001, Florença, S.N., European University Institute.

SAID, Edward. Orientalismo - O Oriente como invenção do Ocidente, São Paulo: Companhia das Letras, 2007 [1978].

SAMSON, George Bailey. Japan: a short cultural history, Tokyo: Charles Tuttle, 1997. . A History of Japan 1334-1615, volume II, Tokyo : Charles Tuttle, 1990. The Western World and Japan: a study in the interaction European Asiatic cultures, Tokyo: Charles E. Tuttle, 1990.

SEABRA, Leonor Diaz de. Macau, a China e o Japão: Uma relação histórica - séculos XVI-XVII. Revista de Cultura, Macau, nº 6, 2003.

SCHEID, Berhard e TEEWEN, Mark. Tracing Shinto in the History of Kami Worship. Japanese Journal of Religious Studies, 29/3-4, p. 195-207, 2002.

SKINNER, Quentin. The foundations of modern political thought. Cambridge; Nova York: Cambridge University Press, 1978.

SINDEMANN, Kerstin-Katja. Japanese Buddhism in the $16^{\text {th }}$ century. Letters of the Jesuit missionaries. In: Bulletin of Portuguese/Japanese Studies, Universidade Nova de Lisboa, vol. 2, p. 111-133, jun-2001.

SUBRAHMANYAM, Sanjay. O império asiático português 1500-1700: uma história política e econômica, Portugal : Difel, 1995. 
TALADRIZ, José Luis Alvarez, Monumenta Nipponica Monographs, Tóquio: Sophia University, v. 9, 1954.

TSANG, Carol Richmond. The Development of Ikkō Ikki, 1500-1570. Tese (doutorado em História e Línguas Asiáticas Orientais), Universidade de Harvard, 1995.

TOTMAN, Conrad. Early Modern Japan, University of Califórnia Press.

VILLARI, Rosário (org.). O homem barroco. Lisboa: Editorial Estampa, 1995.

VIGNERON DE LA JOUSSELANDIÈRE, Victor Santos. Converter civilizar comunicar. Considerações sobre religião, direito e linguagem no Peru colonial. Dissertação (mestrado em História) - Departamento de História Social da Faculdade de Filosofia Letras e Ciências Humanas na Universidade de São Paulo, São Paulo, 2012.

WELTER, Albert. Zen Buddhism as the Ideology of the Japanese State: Eisai and the Kōzen Gokokuron, In: HEINE, Steven e WRIGHT, Dale S. Zen Classics Formative texts in the History of Zen Buddhism, Oxford University Press, 2006.

WORCESTER, Thomas (ed.), The Cambridge Companion to the Jesuits, Cambridge University Press, 2008.

WRIGHT, Jonathan. God's Soldier: adventure, politics, intrigue and power: a history of the Jesuits, New York: Doubleday, 2004.

YAMASHIRO, José. Japão - Passado e Presente, Editora Hucitec, São Paulo, 1978. - Choque Luso no Japão dos séculos XVI e XVII, São Paulo: IBRASA, 1989. . História da Cultura Japonesa, IMBRASA, São Paulo, 1986.

YAMAMURA, Kozo (ed.). The Cambridge History of Japan, vol. 3, Cambridge University Press, 1990.

ZERON, Carlos Alberto de Moura Ribeiro. Linha de Fé-A Companhia de Jesus e a Escravidão no Processo de Formação da Sociedade Colonial (Brasil, Séculos XVI e XVII), tradução de Antonio de Padua Danesi, São Paulo: Edusp, 2011. 
La Compagnie de Jésus et l'instituition de l'esclavage au Brésil: lês justifications d'ordre historique, théologique ET jurudique, ET leus intégration par une mémoire historique (XVI-XVII siècles), Paris: EHESS, 1998.

ZUPANOV, Ines G. História da Expansão Portuguesa, acessível no site http://www.ineszupanov.com. Acesso em: 20/06/10.

. One Civility but Multiple Religions, Paris, Research Fellow, CNRS, 2003. 